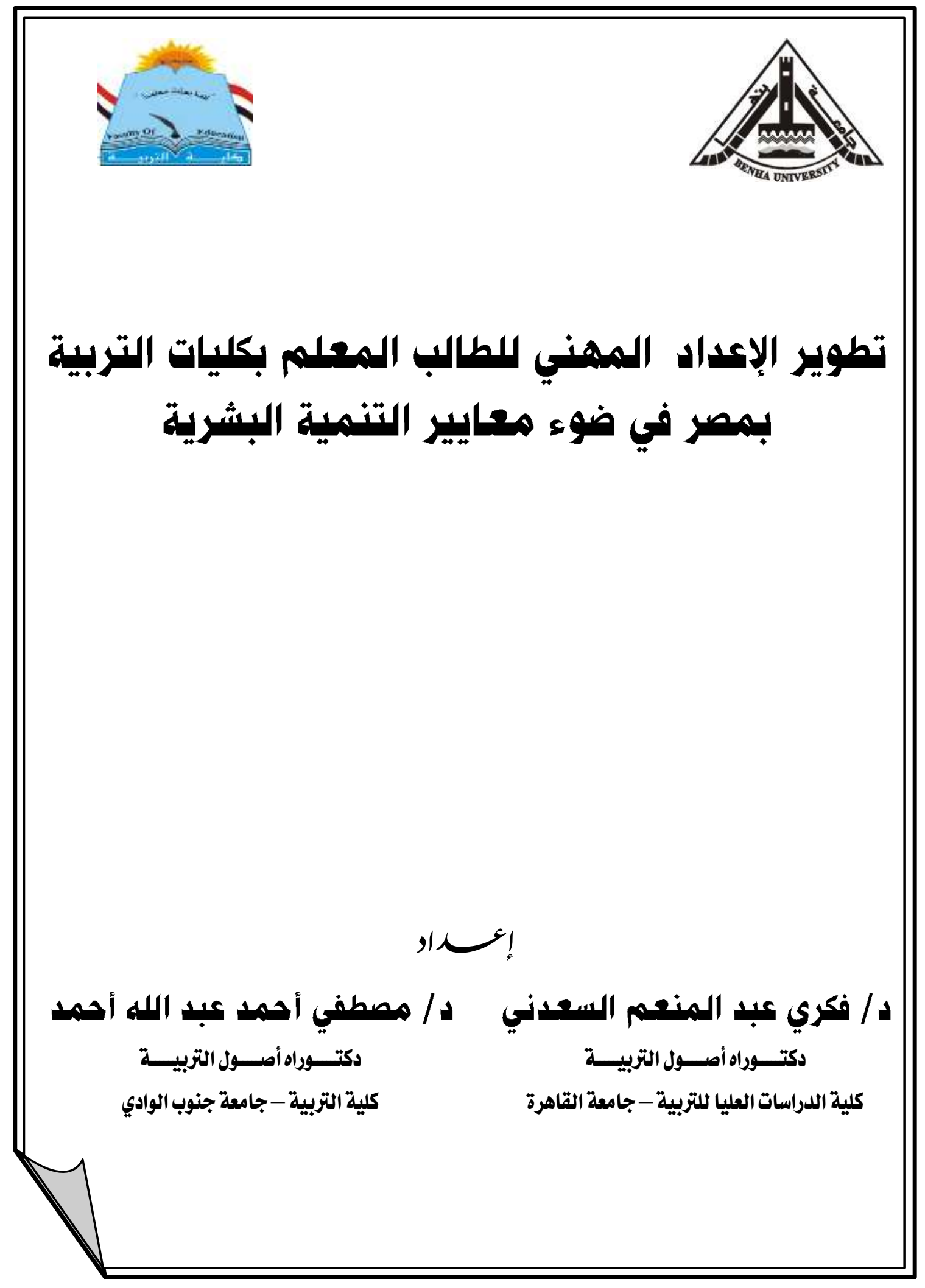




\section{تطوير الإعداد المهني للطالب المعلم بكليات التربية بمصر في ضوء معاييز التنمية البشرية}

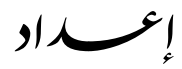

ه/ مصطفي أحمد عبد الله أحمد دكتوراه أصول التربية كلية التربية - جامعة جنوب الوادي
ه/ فكري عبد المنعم السعدني

دكتوراه أصول التربية

كلية الدراسات العليا للتربية - جامعة القاهرة

\section{المبان}

هدفت الدراسة الراهنة إلى تطوير الإعداد المهني للطالب المعلم بكليات التربية بمصر في ضوء معايير التنمية البشرية. وتكونت عينة الدراسة من (0 (1) طالبا من طلاب الفرقتين الثالثـة والرابعـة بكليتـي التربيـة عـام وطفولـة وتعلـيم أساسـي بجـامعتي أسـيوط والسـادات. واستخدمت الدراسة المنهج الوصفي واعتمدت على استبانة تكونت من (Y I) معيارا، تم عرضها في (^r) مؤشرا. وقد توصلت الدراسـة إلى عدة نتائج ، قدمت بعدها التصـور المقترح، ومـن أهم هذه النتائج: تحقق معايير الدراسة من وجهة نظر الطلبة المعلمين أفراد عينة الدراسة بدرجة متوسطة لمعايير (مهارات الاتصال اللفظي، التقييم والتقويم، الوسائل والتقنيات التعليمية، التتمية المهنية الذاتية، تتمية شخصية الطالب، إدارة الصف الدراسي). في حين تحققت باقي المعايير وفي مقدمتها ( التخطيط للدرس، الإلمام بالمعارف اللازمة للتخصص) بدرجة مرتفعة. الكلمات المفتاحية: الإعداد المهني - معايير التنمية البشرية. 


\section{Abstract}

The present study aims to develop the professional preparation of the student teacher in the faculties of education in Egypt in the light of human development standards. The study sample consisted of (415) students. Of the students of the third and fourth branches of the Faculty of Education, General and Childhood and basic education at the Universities of Assiut and Sadat. The study used the descriptive approach. It was based on a questionnaire consisting of (12) criteria, which were presented in (82) indicators.

The study reached several conclusions, after which the proposed scenario was presented, and the most important of these results: The criteria of the study were achieved from the point of view of the student teachers in the sample of the study to a medium level of standards (verbal communication skills, evaluation and evaluation, methods and techniques of education, self-professional development, personal development of the student, classroom management). the rest of the criteria, namely (planning the lesson, knowledge of the knowledge required for specialization), achieved a high degree.

Keywords: Professional preparation - Human development standards. 
يحدث التعلم نتيجة التفاعل بين استعدادات الطالب المعلم، وقدراته العقلية، وسماته ومهاراته الثخصية من جهة، وبين بيئة التعلم وما تحويه من مادة تعليمية، وطريقة تدريس، ومعلمين، ووسائل، وأنثطة من جهة أخرى. ويعد المعلم أحد أهم مقومات العملية التعليمية وأحد دعائمها الأساسية التي تحدد مدى ولئ

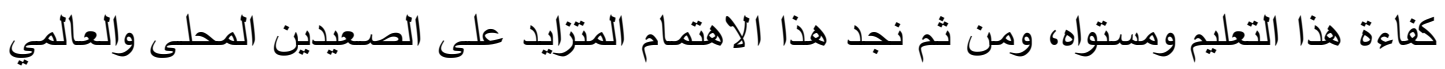

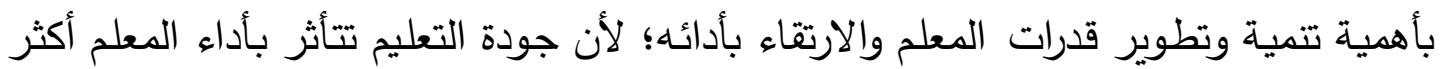

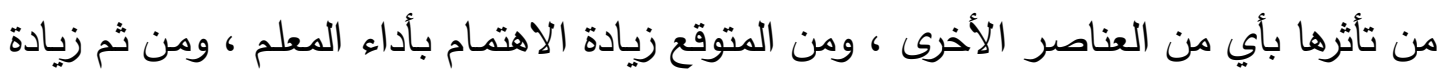

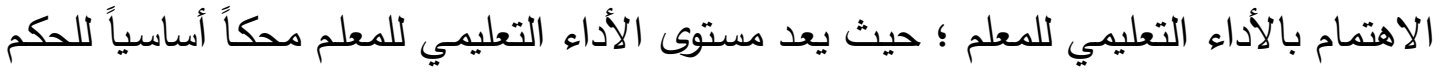

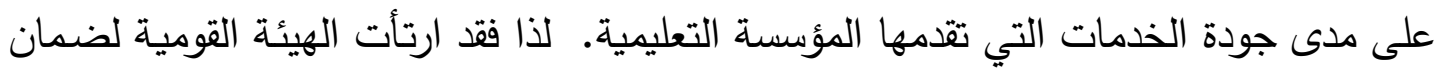
جودة التعليم والاعتماد المصرية القيام بتحديد إطار مرجعي لمعايير الممارسة الأكاديمية للتعليم تقوم على أساسه مؤسسات التعليم العالي بتطوير الإعداد المهني لمعلميها (طارق عامر ، إيهاب الإنياب

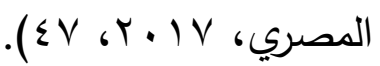

ونظرًا لمتطلبات الوضع التعليمي المعاصر وتزايد المعرفة فى كل لحظة ، فإن المطالب المهنية المتزايدة على المعلم تغرض عليه أن يكون ممتلكاً لجانبي الإعداد التخصصي والتربوي

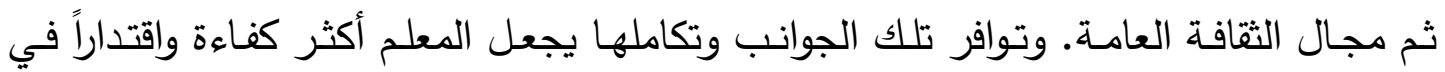
تحقيق الأهداف التعليمية. ولما كانت المعرفة النظريـة التخصصية أحد العناصر الرئيسة في ولهي الإعداد المهني، فقد أصبح من الضروري أن يتضمن برنامج إعداد المعلمين إكسابهم المعرفة النظريـة التخصصية في حقل معين من حقول المعرفة ، يقوم الطالب بدراسته والتعمق فيه

$$
\text { والتمكن منه ليتولى تدريسه (عبد السلام فريوان، V .. . r، ro م). }
$$

كما يسعى كثير من بلدان العالم للارتقاء بالعملية التربوية ، وتعد درجة الاهتمام بإعداد

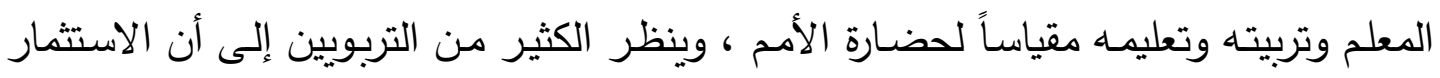

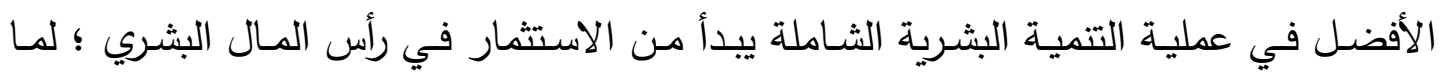
يمتلكه من قدرات ومهارات ، وأن أول خطوات هذا الاستثمار تبدأ في عملية إعداد المعلم نفسها الذي يشكل الأساس في نقل المعارف والمهارات وتثكيل القيم وتطويرها وتوجيهها. 
ولم يعد يُنظر إلى إعداد المعلمين قبل الخدمة على أنه عملية تتتهي بحصول الطالب

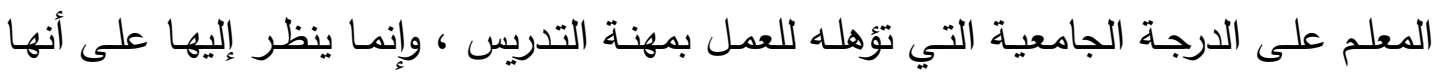

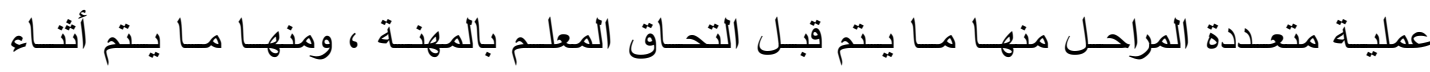
ممارسته للتتريس.

وتتطلب عملية التتمية البشرية للطالب المعلم جهدا كبيرا ووقتا كافيا ومساعدة مستمرة في تعلم أي سلوك تعليمي جديد يعدل أو يضيف ، أو يحل محل السلوك التعليمي شبه الثابت

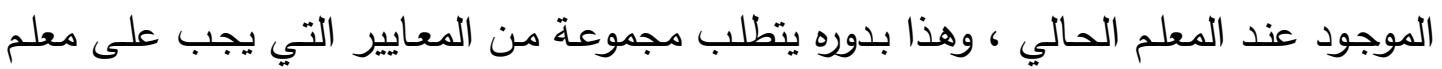

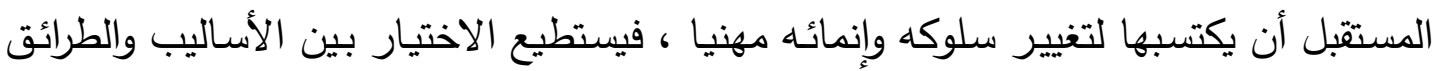

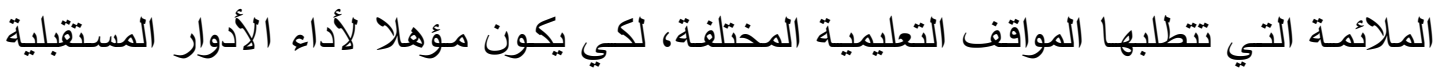

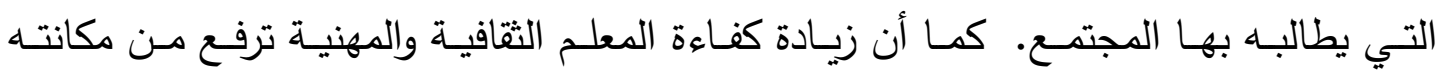

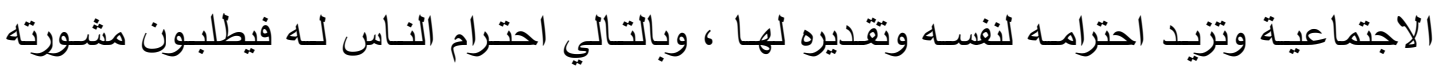

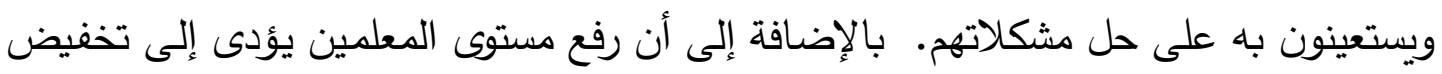

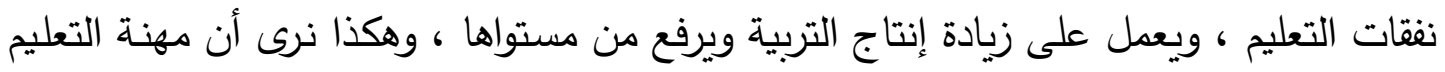

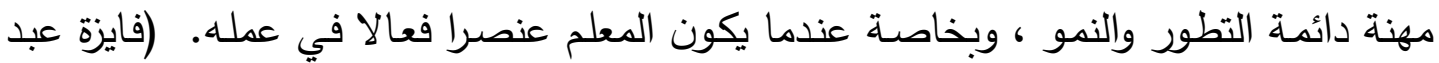

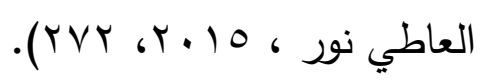

وتمثل معايير التنمية البشرية للمعلم بصفة خاصة إحدى الآليات التي يتم من خلالها

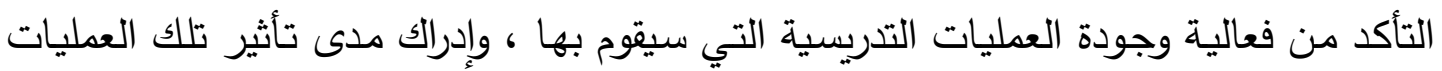

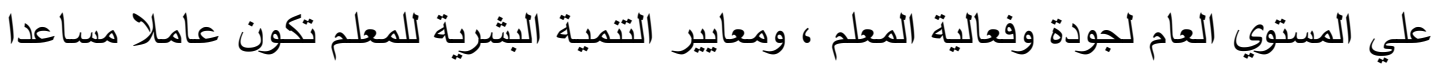

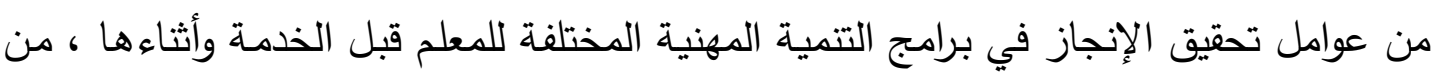

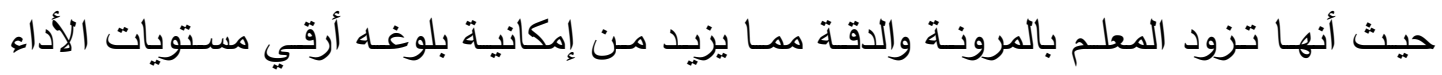
الأكاديمي والإداري في ظل نظام الإصلاح المدرسي.

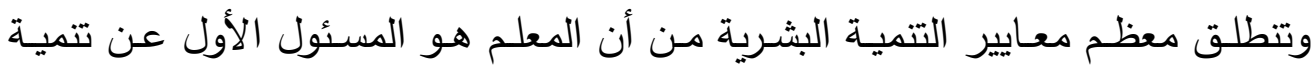

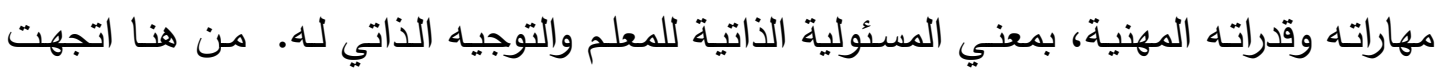

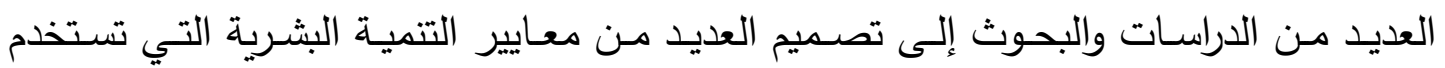

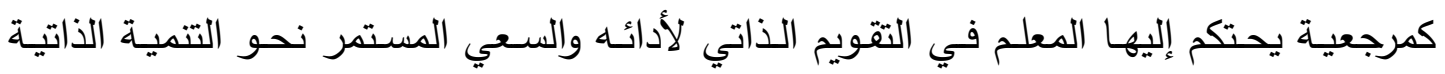
المستمرة ، وتوفير رؤية أكثر وضوحا لدوره وإلماما أكثر بمهامه ومسئولياته المستقبلية ، وتقييم 
إنجازاته، وترسيخ قيم الثفافية والتنافسية ، وتطبيق مبادئ المسئولية والمحاسبة ، والتخطيط

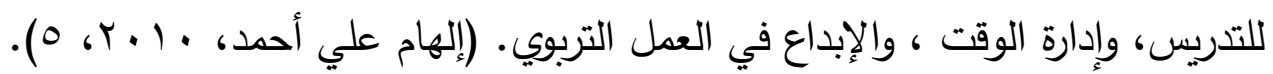
وعلى ذلك فثمة ضرورة لوضع تصور مقترح لنموذج مبني علي معايير التتمية البشرية الإنية لتطوير الإعداد المهني للطالب المعلم بكليات التربية.

على ضوء ما سبق يمكن القول إن مسألة إعداد المعلم في وقتتا الحالي تعد إثكالية مهنية في ظل التغيرات التي تفرضها تطورات الحياة ، ومواكبة القرن الحادي والعشرين من فئن

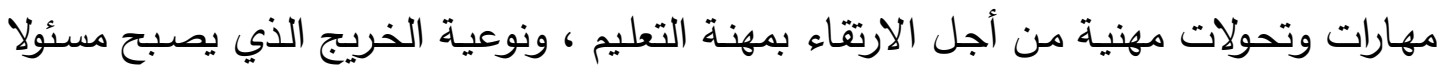

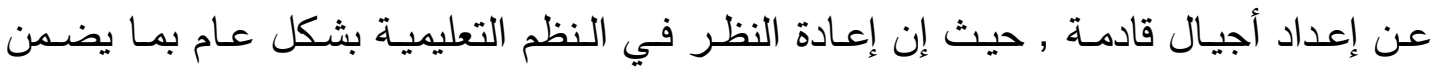
استدامة في التتمية والتطوير من قدرات ومهارات المعلم ، ودعم المكانة المهنية للمعلم ويمكنها

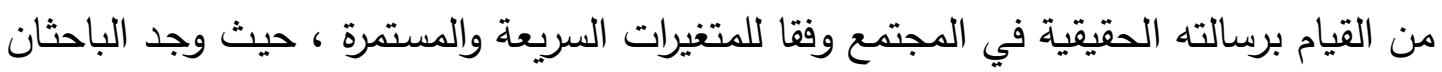

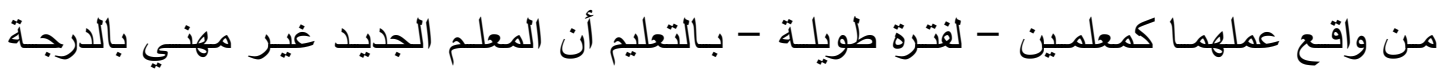

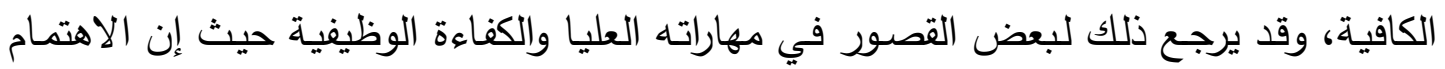

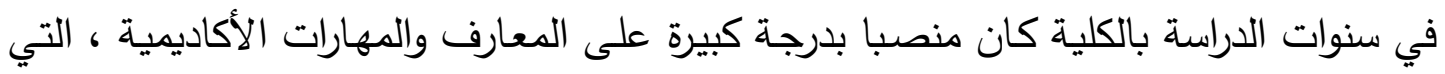

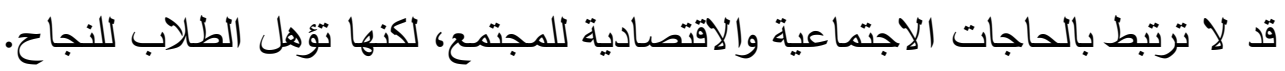

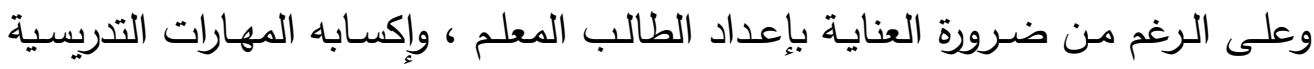

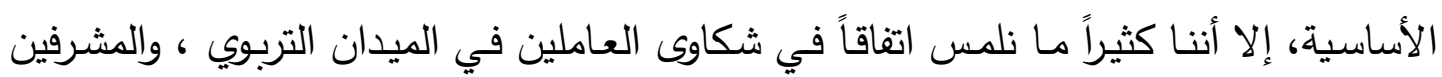

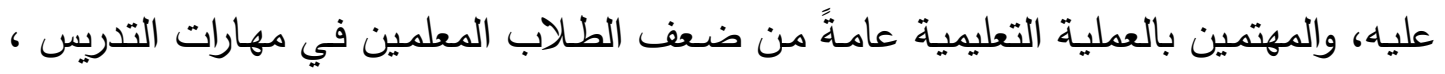

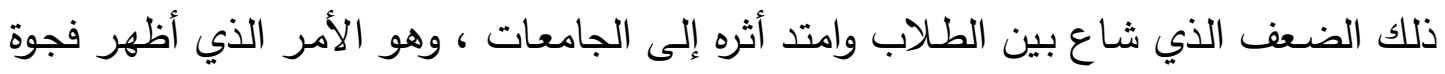

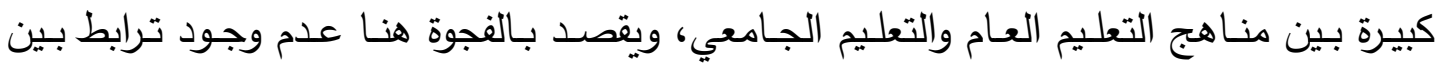

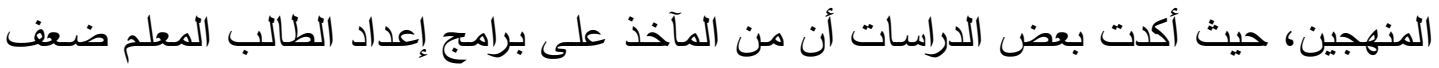

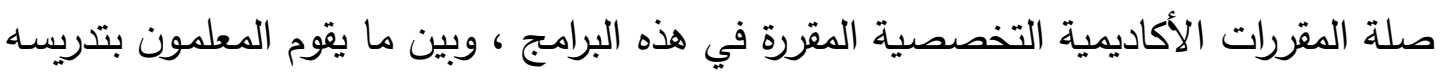
في المدارس بعد تخرجهم , ومن تلك الدراسات:

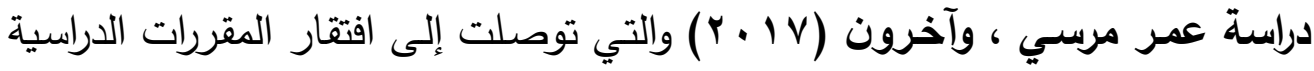

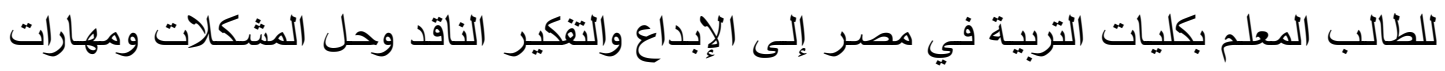

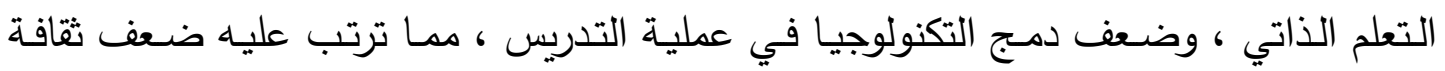


التطوير المهني لدى الطالب المعلم ، وكذلك تدني ثقافة التتمية المهنية المستدامة لديه. وكذلك

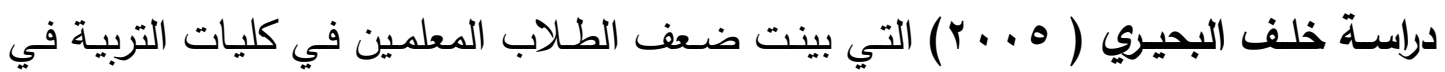
المهارات التدريسية وافتقارهم إلى برنامج في تلك المهارات ؛ للارتقاء بمستوى الأداء التدريسي لبعي

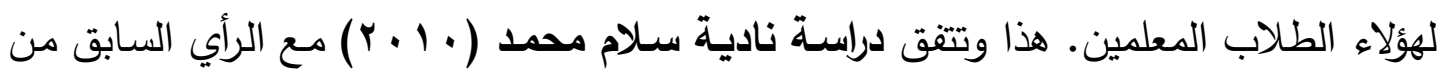

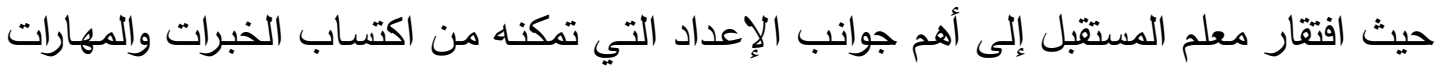

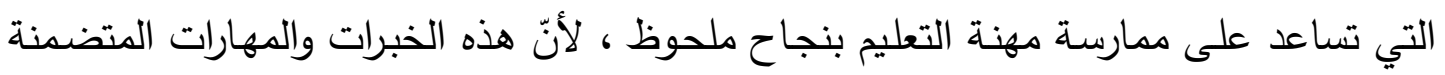

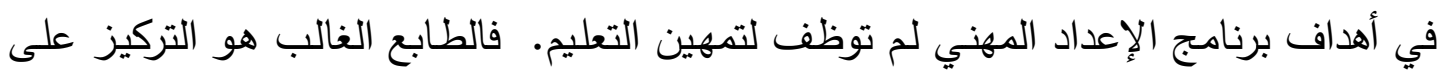
الجوانب النظرية على حساب الجوانب التطبيقية الأمر الذي ترتب عليه إهمال المهارات الهامة مثل: توظيف طرائق التدريس الحديثة ، وتصميم الوسائل التعليمية واستخدام التقنيات في التعليم الصفي. واستخدام أساليب متنوعة في التقويم وغيرها من المهارات.

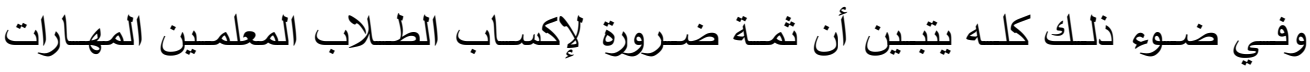

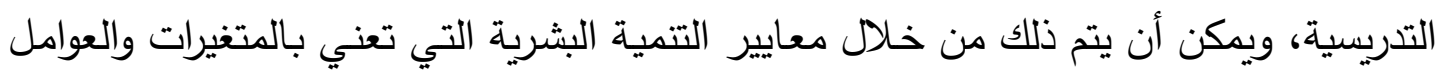

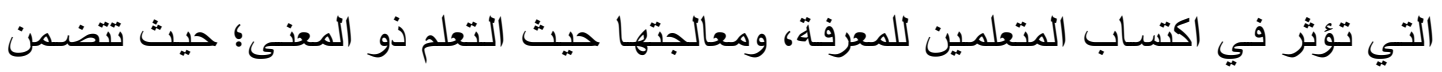

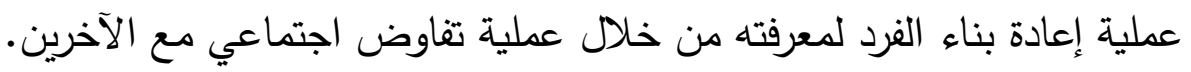

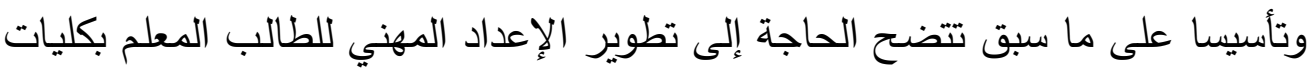
التربية بمصر وفق معايير التتمية البشرية. وعليه يمكن صياغة مشكلة البحث الراهن في التساؤلات الآتية :

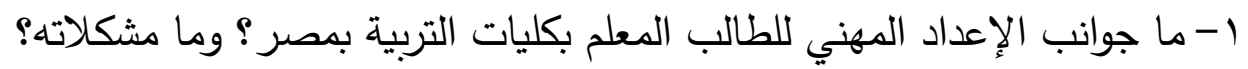

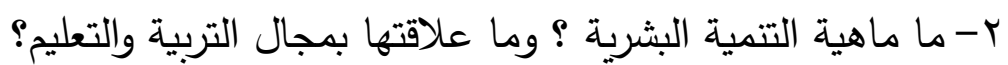

r- ما معايير التنمية البشرية المتعلقة بالإعداد المهني للطالب المعلم بكليات التربية؟ هالئه

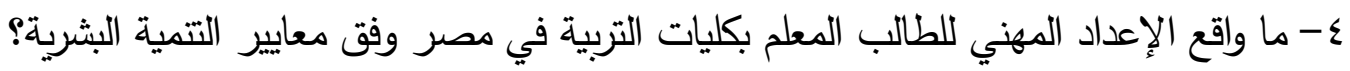

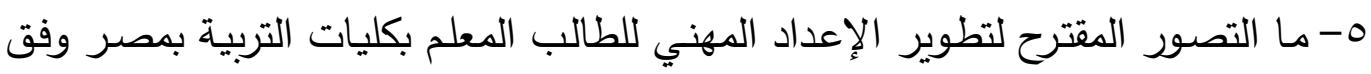

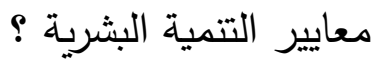

\section{يسعى البحث الراهن إلى: - الى}

1- الوقوف على جوانب الإعداد المهني للطالب المعلم بكليات التربية بمصر . 
r- التعرف على ماهية التتمية البشرية ، وعلاقتها بمجال التربية والتعليم.

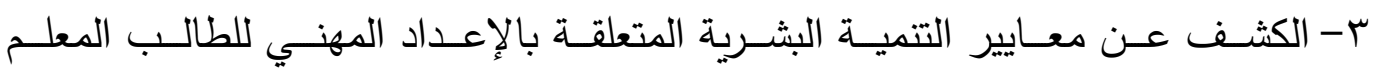

بكليات التربية.

ع- رصـد واقـع الإعداد المهني للطالب المعلم بكليـات التربيـة في مصـر وفق معـيير

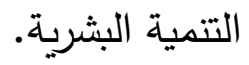

ه-وضع تصور مقترح لتطوير الإعداد المهني للطالب المعلم بكليات التربية بمصر وفق معايير التنمية البشرية.

من المتوقع أن يسهم البحث الراهن بما يأتي:

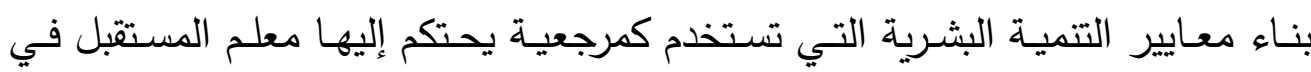
التقويم الذاتي لأدائه.

"إلقاء الضوء على المهارات والمعارف والممارسات الأساسية اللازمة لتحقيق تتمية بشرية لإنهاتئ.

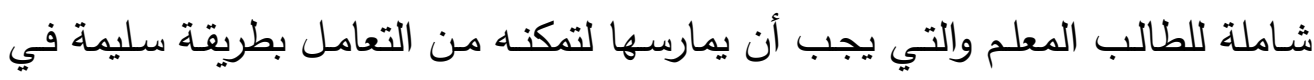
حياته المهنية والمجتمعية. تأكيد توصيات المجالس القومية المتخصصة والتماشي معها ؛ بغية رفع كفاءة ومستوى ولهي الطالب المعلم لتحقيق الجودة التدريسية الثاملة. هواكبة الخبرات العالمية للدول المتقدمة في مجال تحديد المستويات المعياريـة للتنمية البشرية للمعلم وفقا لظروف وإمكانات المجتمع المصري.

مساعدة الطالب المعلم بكلية التربية على التمكن من مهارات التدريس (التخطيط التنفيذ - التقويم ) في ضوء معايير التنمية البشرية.

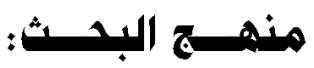

نظرا لطبيعـة المشكلة تستخدم الدراسـة المنهج الوصفي الذي يفيد في رصد ظـاهرة

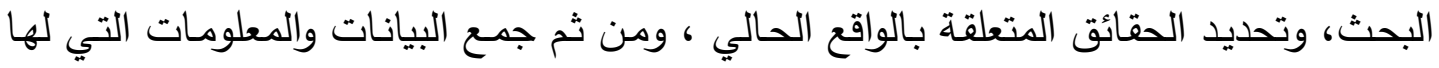

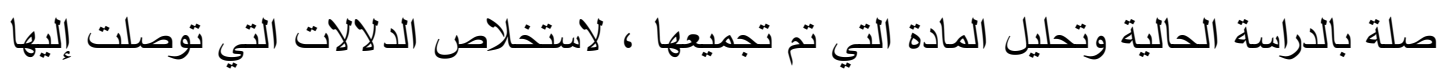

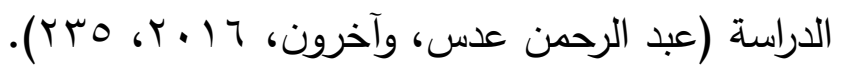


يقتصر البحث الراهن على الحدود التالية:

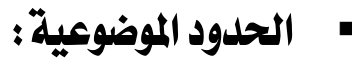

وضع تصور لنموذج مقترح لبناء معايير التتمية البشرية لدى الطالب المعلم.

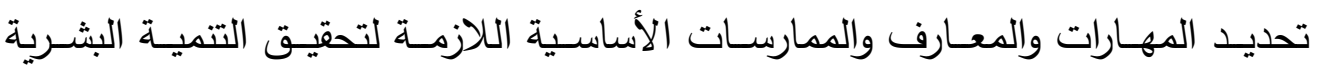
المستدامة لدى الطالب المعلم وصياغتها في شكل نواتج تعلم وأداءات سلوكية يمكن

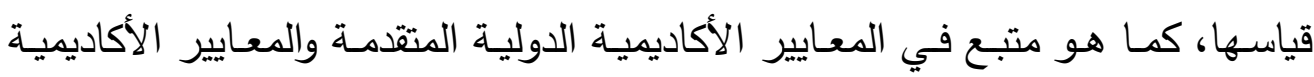
القياسية المطبقة في الكليات المناظرة. وضع مجموعة من المعايير ، ويتضمن كل معيار standard مجموعة من المؤشرات Indicators

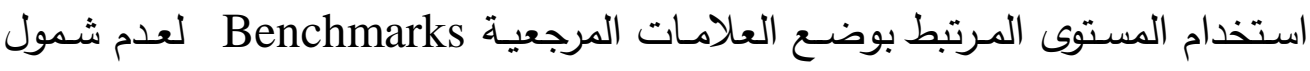
المعايير الأكاديمية الدولية المتقدمة والمعايير الأكاديمية القياسية المطبقة في الكليات المناظرة على صياغة هذا المستوى بالنسبة لمعايير التنمية البشرية للمعلم.

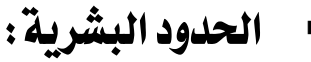

تقتصر الدراسة على عينة من طلبة الفرقتين الثالثة والرابعة بكليتي التربية عام وطفولة وتعليم أساسي، بجامعتي أسيوط والسادات، وتم اختيار الكليتين نظرا لحصولهما على الاعتماد

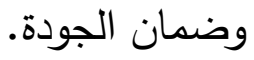

\section{• الحدود المكانية والزمانية :}

تقتصر الدراسة على طلبة كليتي التربية عام وطفولة وتعليم أساسي ، بجامعتي أسيوط

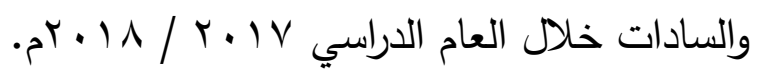

1- الإعداد المهنى: المقصود بالإعداد المهني للطالب المعلم إجرائيا هو تزويد معلمي المستقبل

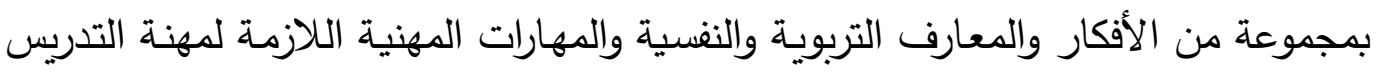
إلى جانب ممارسة التدريس الموجه أو ما يسمي بالتربية العملية للطالب المعلم. 
r-معايير التنمية البشرية : تعرف معايير التتمية البشرية اجرائياً بأنها: عبارات تصف ما يجب أن يصل إليه طلاب كلية التربية من معارف ، وقيم ، وممارسات تطبيقية لضمان الإعداد المهني الجيد لمعلم المستقبل، وذلك في ضدوء إلمامـه بالمهارات الآتية ( الإلمام بمعـارف التخصص - التخطيط للدرس - توظيف طرائق وأسـاليب تدريس - استخدام مهارات الاتصال اللفظية وغير اللفظية - إثارة الانتباه والدافعية - تطوير التفكير - إدارة الصف الدراسي - استخدام الوسائل والتتنيات التعليمية - التتييم والتقويم - تطبيق الأنشطة

$$
\text { المتتوعة - التعاون مع الزملاء في العمل - تطوير الذات). }
$$

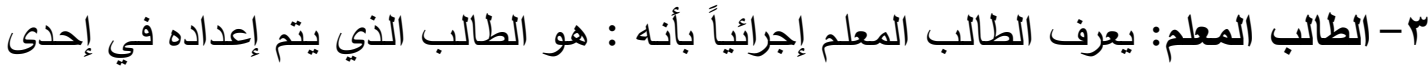

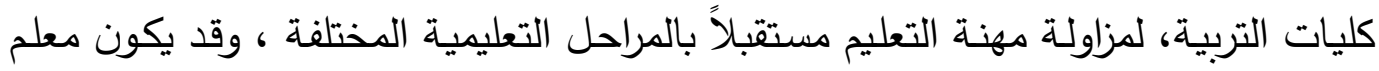

$$
\text { صف أو معلم مادة. }
$$

\section{السدراسـات السـابة السـة:}

تتسم الدراسة الحالية بعدة متغيرات منها: الإعداد المهني، التتمية البشرية ، لذا وفي ضوء ذلك يستعرض الباحثان أهم الدراسات السابقة التي تتاولت تلك المتغيرات ، فقد هدفت

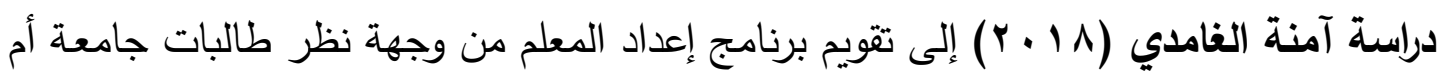
القرى في ضوء معايير جودة الأداء المهني للمعلم في المملكة العربية السعودية ـ واستخدمت بله

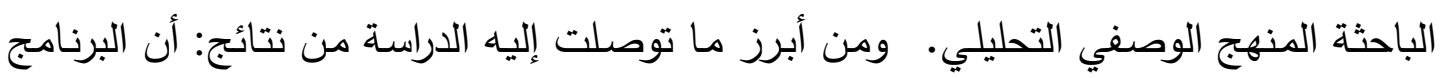
الحالي لإعداد المعلم بكلية التربية جامعة أم القرى لم تتوفر فيه معايير الجودة بدرجة كبيرة وأنه يعاني من قصور مما يستوجب إعادة النظر في مكوناته.

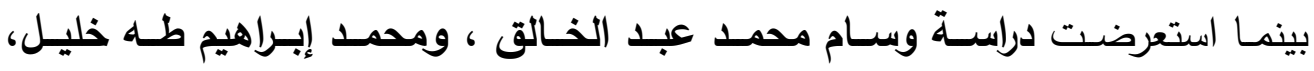
واقع إعداد معلم اللغة الإنجليزية بكلية التربية جامعة طنطا في ضوء معايير الجودة.

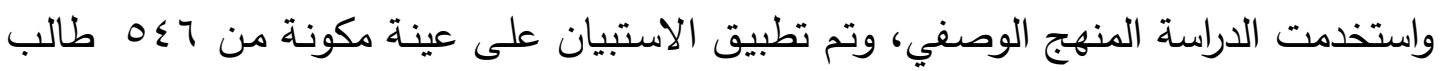

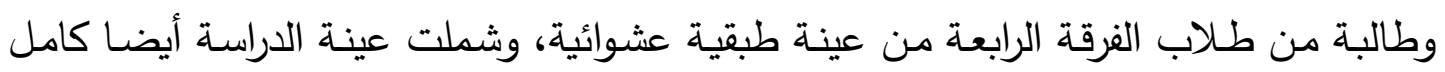
أعضاء هيئة التدريس الذين يدرسون للقسم وعددهم (ه (1) عضو هيئة تدريس. وكثفت نتائج

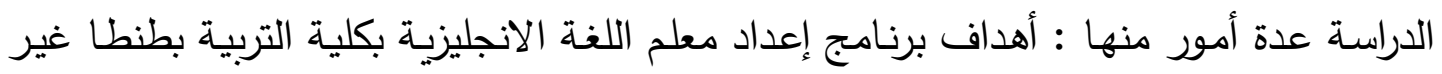
واضحة بالقدر الكافي، وضعف التوازن في جوانب الإعداد المختلفة. 
وسعت دراسة نظمية فخري حجازي (10 ب ب) إلى التعرف على مدى تطبيق معايير

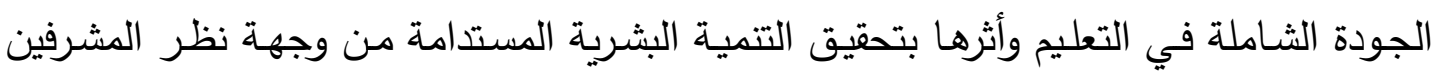

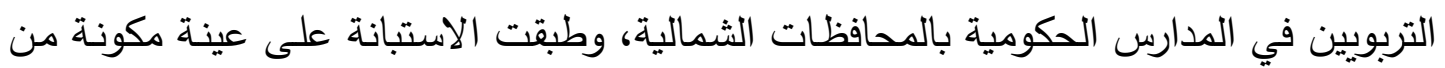

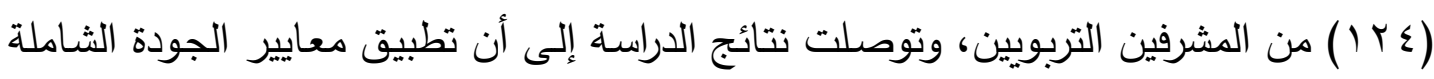

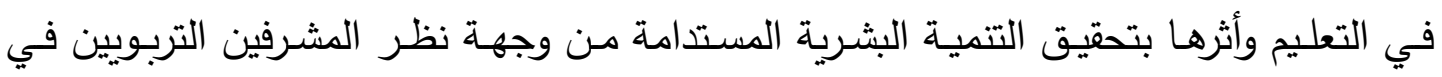

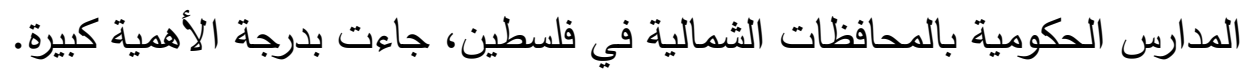

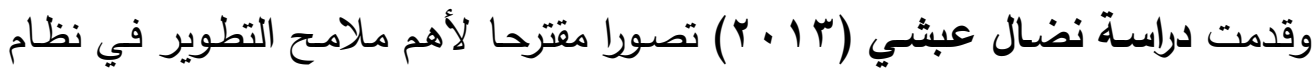
إعداد المعلم بكليات التربية من خلال التعرف على واقع نظام إعداد المعلم بكليات التربية وأهم

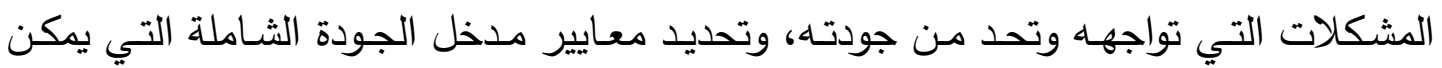
تطبيقيا والاستفادة منها في تطوير نظام إعداد المعلم بكليات التربية، وبيان مدى توافر معايير

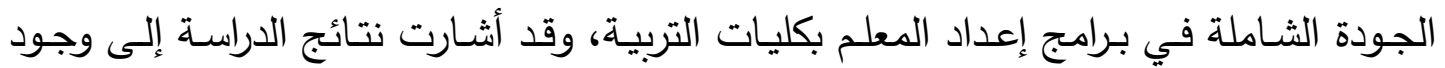

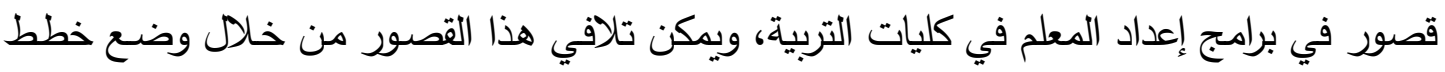
وبرامج تستدا إلى مدخل الجودة الثاملة لبرامج الإعداد في تحقيق الأهداف والغايات المنشودة.

\section{الإطسـار النظــري للبدــث:}

تعد قضية الإعداد المهني للطالب المعلم من أهم الموضوعات العصرية التي اهتمت التصد

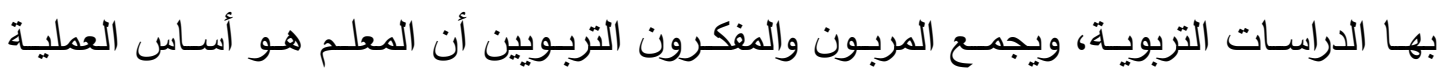

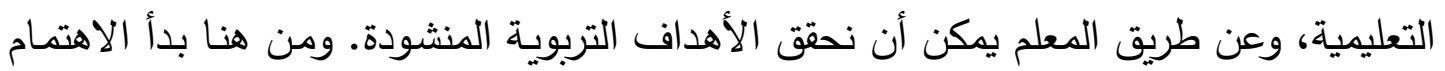

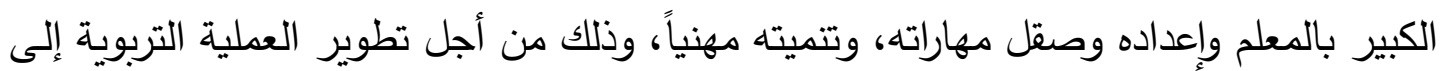
الأفضل، والوصول بمهنة التدريس إلى أن تصبح مهنة مثل غيرها من المهن الأخرى. ويتناول البحث في إطاره النظري محورين رئيسين هما:

$$
\text { هوانب إعداد المعلم في كليات التربية. }
$$

ه معايير التتمية البشرية وعلاقتها بالإعداد المهني للطالب المعلم.

\section{أولا : إعداد الطالب المعلم في كليات التربية:}

لقد بذلت في الآونة الأخيرة جهود عدة لتطوير كليات التربية، تحقيقا لما انتهى إليها

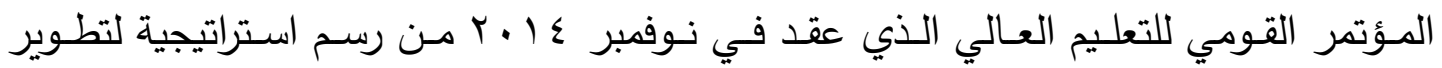

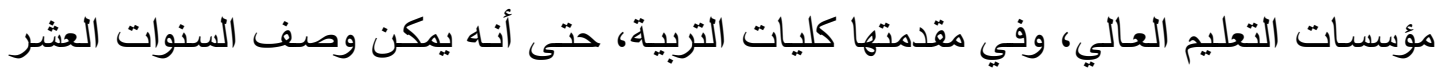


الأولى من القرن الحادي والعشرين بأنها عقد التطوير في كليات التربية في معظم الدول العربية

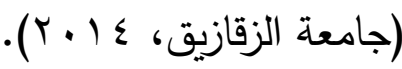

وقد جاء هذا الاهتمام إيمانا بالدور الذي تؤديه كليات التربية في تكوين المعلم، حيث

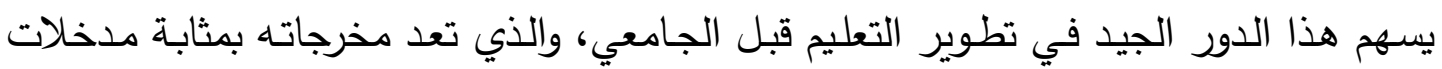

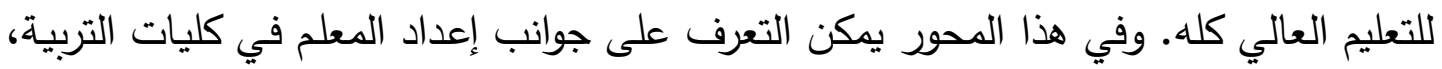

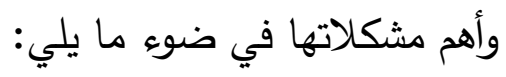

\section{ا- جوانب إعداد الطالب المعلم في كليات التربية:}

لقد أدى الطلب المتزايد على مهنة التعليم ، والحاجة إلى المعلمين، والتطورات التاريخية

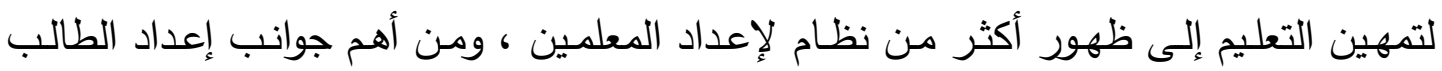

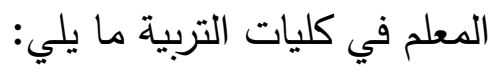

\section{أ أ) الإعداد الأكاديمي:}

يهذف الإعداد الأكاديمي إلى تزويد الطالب المعلم بالمعرفة التي سوف يتخصص فيها

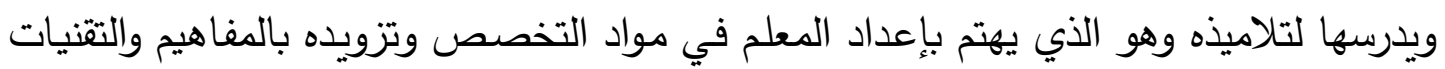

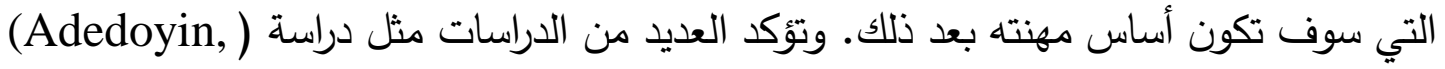

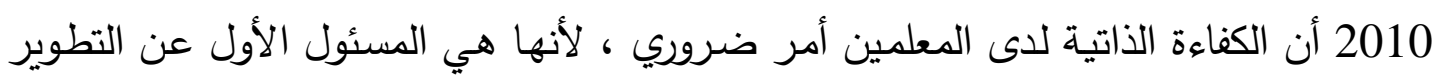

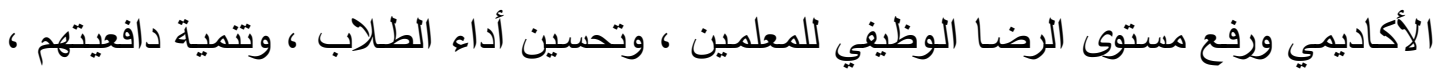

$$
\text { وتحسين مستوى إنجازهم. }
$$

ولذلك يرى الباحثان أن تهيئة البيئة الملائمسة للتعلم تعتمد على كفاءة المعلم الذاتية ؛ فالمعلم الذي يملك الكفاءة الذاتية يساعد الطلاب بمختلف مستوياتهم ويبني دافعيتهم وثقتهم

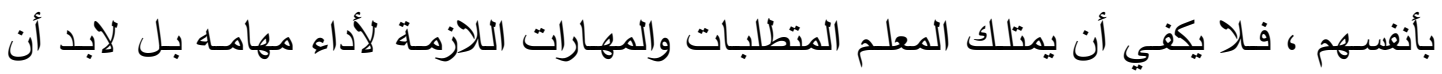

يمتلك الإيمان والثقة بقدرته على القيام بالعمل المتوقع منه تحت مختلف الظروف الصعبة.

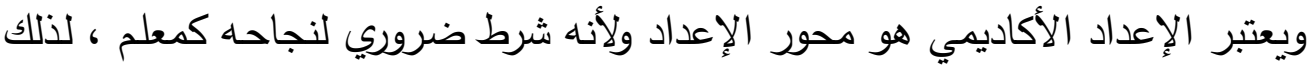

يجب أن يتوافر في إعداد المعلم في هذا الجانب شرطان أساسيان (Artino, 2012, 80): تدريب الطالب على طرق التفكير العلمي ، وإكسابه مهارة حل المشكلات.

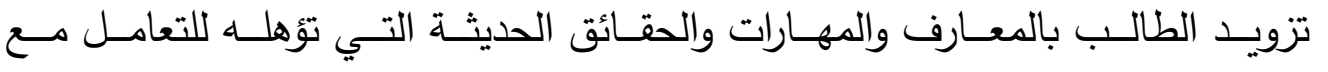
منطلبات المجتمع. 


\section{ب) الإعداد التربوي (المهني):}

يُعرّف الباحثان الإعداد التربوي للطالب المعلم على أنه : إعداد بنائي يستهدف إكساب

الطلاب المعلمين مهاراتهر ، وكفاياتهم المعرفية والتربوية والتقنية والإدارية والأخلاقية.

وعلى ذلك فالإعداد المهني يمد الطالب المعلم بالمعلومات والمهارات التي تؤهله وتمكنه

من القيام بمهنة التدريس ، كما أنه هو الذي يحول التعليم دن حرفة إلى مهنة لها أصولها العلمية، وتتمثل أهمية الإعداد المهني في قدرته على تزويد الطلاب المعلمين بقدرات تتؤهلهم

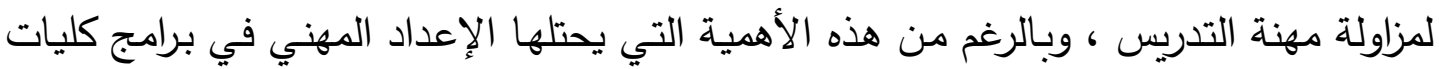

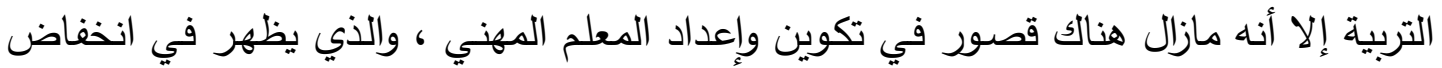

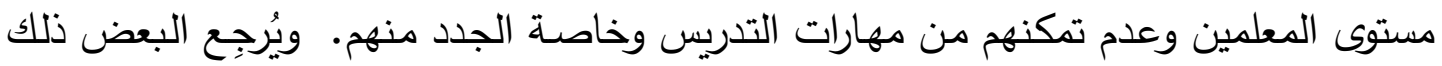

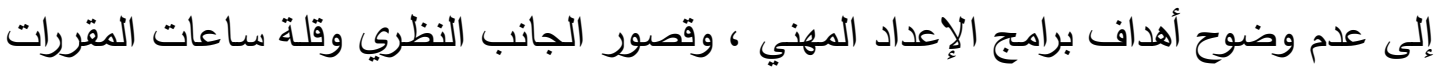

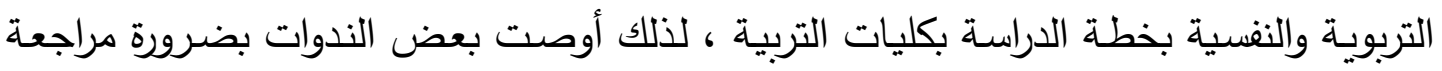

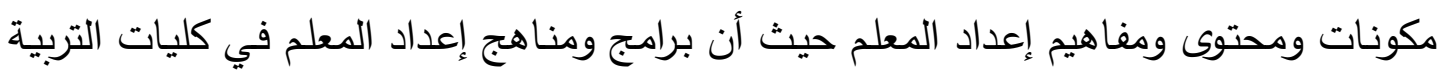

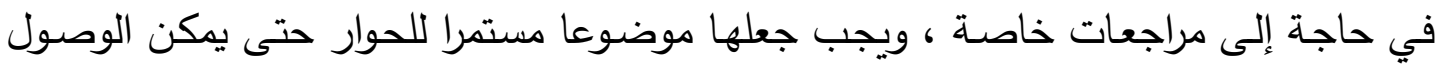

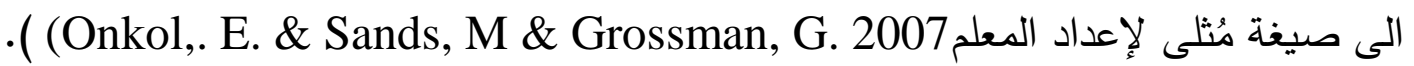

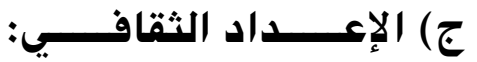

يهدف الإعداد الثقافي داخل كليات التربية إلى تنمية مدركات الطالب المعلم حول

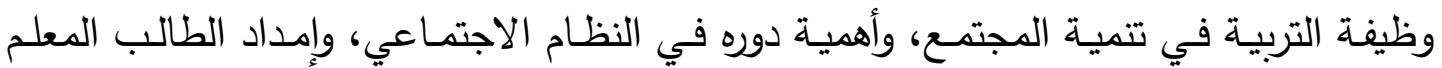
بثقافة عصرية عريضة تمكنه من الوقوف على العناصر الثقافية والحضارية السائدة في مجتمعه

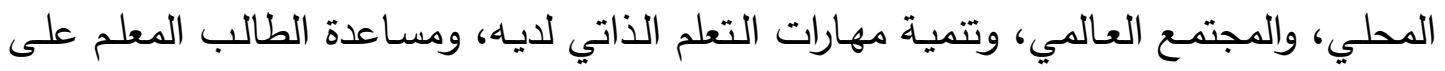

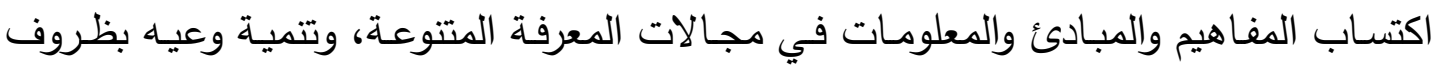

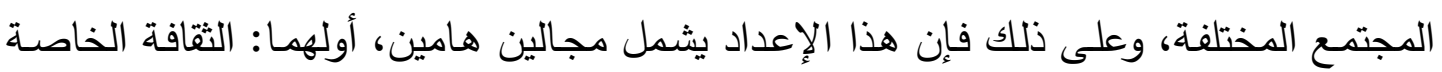
المرتبطة بمادة تخصص الطالب، وثانيهما: الثقافة العامة التي تتناول المعرفة العالمية السائدة

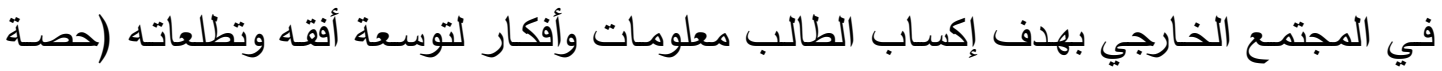

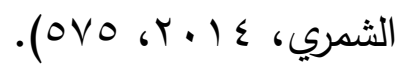

\section{د) التربيتة العمليتة ( الميدانيتة ) :}

تمثل التربية العملية المختبر التربوي الذي يطبق فيه الطالب المعلم المبادئ والنظريات وطرائق التدريس التي تم تناولها بشكل نظري ، وممارستها بشكل تطبيقى في بيئة تعليمية قد لد لتربه 
تؤثر فيها كثير من العوامل والمعوقات التي تحتاج من الطالب المعلم المهارة في إدارة هذه المواقف ومعالجة هذه المعوقات. كما أن التربية العملية تمد الطالب المعلم بالدعم الكافي والخبرة الواقعية لإعداده للتدريس داخل غرفة الصف ، ويتوقف نجاح الطالب المعلم في القيام بهذا الدور على مدى تدريبه على مهارات التدريس ، لأن ذلك ينعكس على أداء طلاء طلابه الأكاديمي

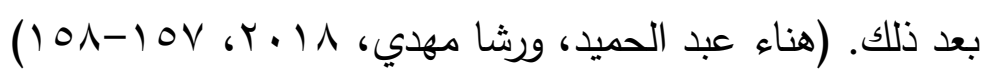

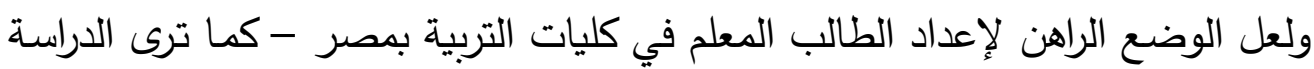

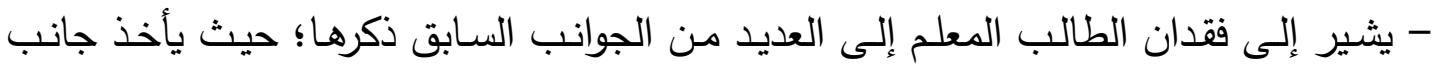

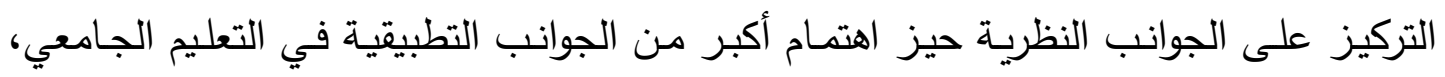

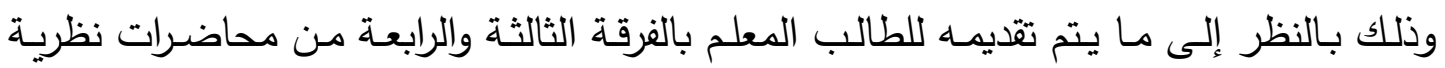

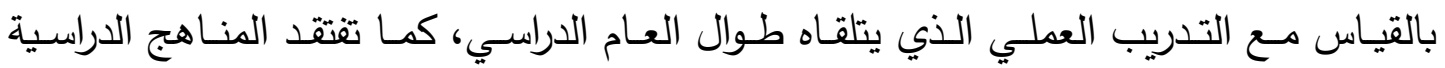

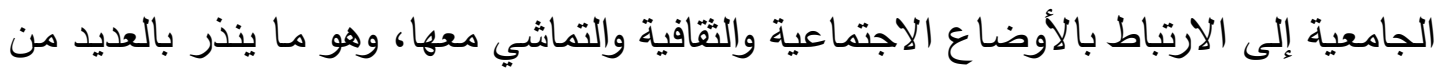

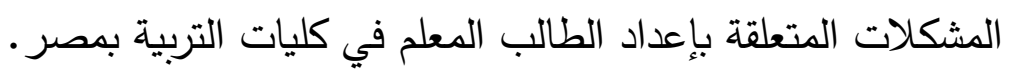

r - مشكلات إعداد الطالب المعلم :

تتعدد مشكلات إعداد الطالب المعلم في الجوانب المختلفة للإعداد، ومنها (نوال شرف، $:(1 \leq \leqslant 7,6) \leq \leqslant 0, r+1 V$

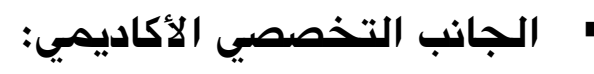
وتتمثل أهم مشكلات هذا الجانب فيما يلي: خلو المحتوى الدراسي من القضايا والمشكلات التي تخص المدابل المجتمع. • المحتوى الدراسي لا يعد المعلم للحياة المعاصرة ولعصر المعرفة. • إهمال الجانب التطبيقي مما يقلل من مهارات المعلم.

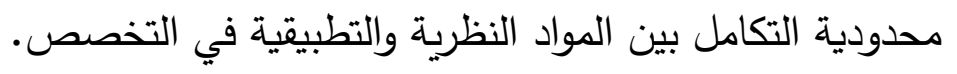

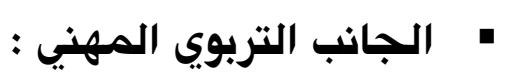
وتتمثل أهم مشكلات هذا الجانب فيما يلي: • تكرار وتداخل المحتوى الدراسي لبعض الدقرات الدئن الدراسية التربوية. قصور ربط المقررات الدراسية التربوية بمشكلات المجتمع وكيفية حلها. •استخدام طرق تدريس تقليدية نتيجة لضعف الإمكانات الاقتصادية. 


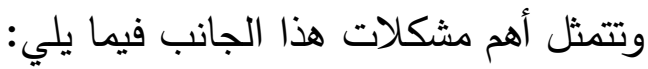

الاقتصار على المواد الثقافية التي يدرسها الطالب في التيات الكلية فقط. غياب الاهتمام بالثقافة العامة المحيطة بالطالب. • قلة معلومات الطالب خارج نطاق التخصص الأكاديمي.

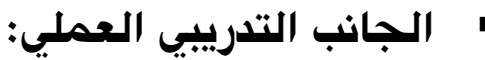

وتتمثل أهم مشكلات هذا الجانب فيما يلي: الجئي

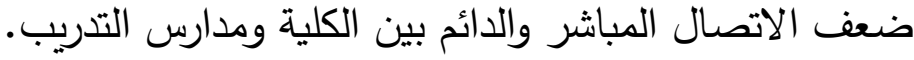

• قلة كفاية المشرفين على طلاب التدريب العملي بالمدارس.

• تكاسل بعض المشرفين وتغيب بعضهم عن الانتظام في الحضور إلى المدارس أسبوعيا.

هقلة التزام بعض أعضاء هيئة التدريس بمتابعة دفاتر التحضير للطلبة.

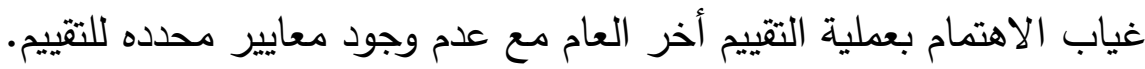

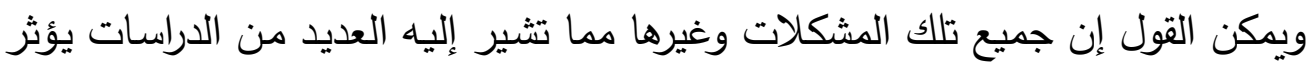

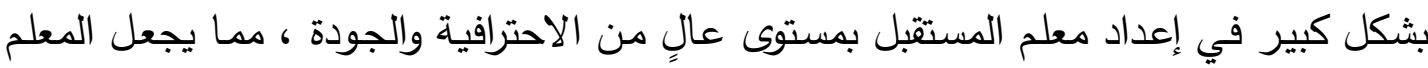

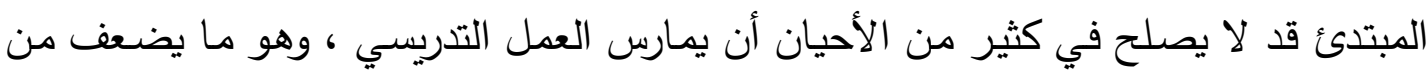

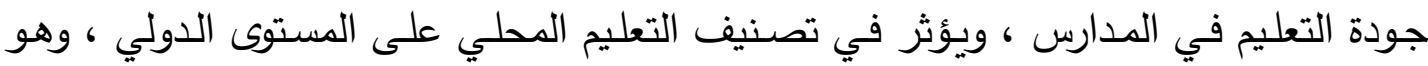

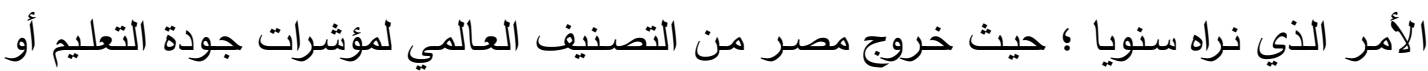

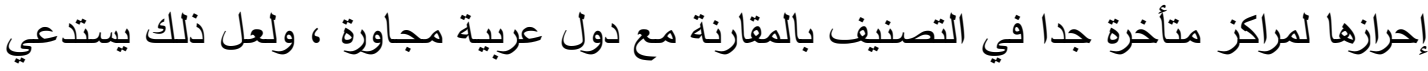

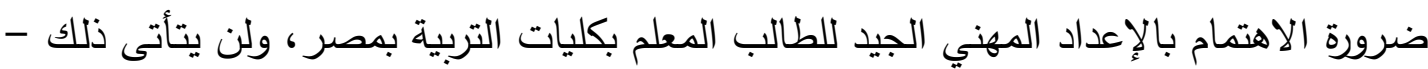

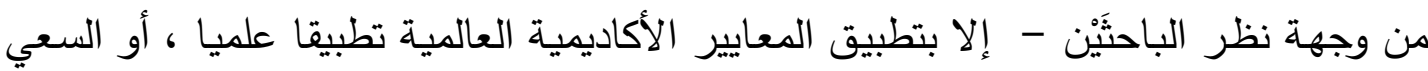

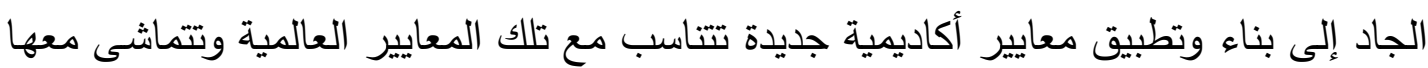
وذلك وفق الإمكانات المحلية لتحقيق التتمية البشرية اللازمة لمعلم المستقبل.

\section{ثانيا : معايير التنمية البشرية :}

جاء لفظ المعايير في اللغة بمعنى: أعاره : جعل يعير ، وعاير بين مكيالين معايرة،

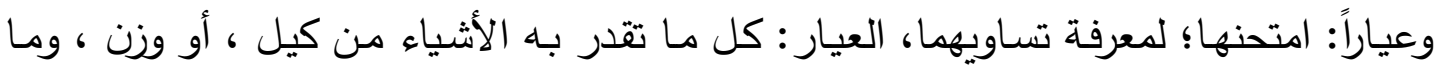

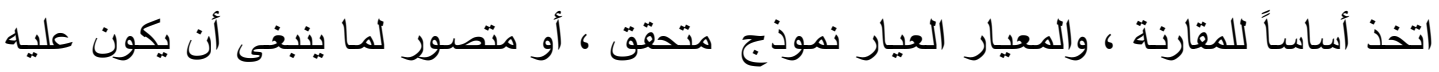

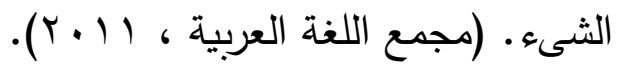


وفى وثيقة المعايير القومية للتعليم فى مصر بأنها: عبارات تصف ما يجب أن يصل إليه المتعلم من معارف، ومهارات، وقيم نتيجة لدراسته محتوى كل مجال. (وزارة التربية والتعليم،

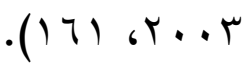

وعرفها طعيمة وآخرون (1 . . r) بأنها "أهداف وطموحات نسعى إلى الوصول إليها،

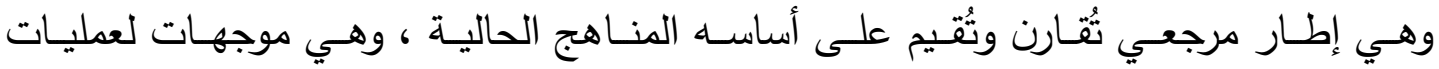

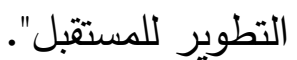

ويمكن تعريف المعايير إجرائيا بأنها: المواصفات القياسية التي ينبغي للطالب المعلم امتلاكها حتى يكون قادرا على تقديم أفضل ما لديه من أداء.

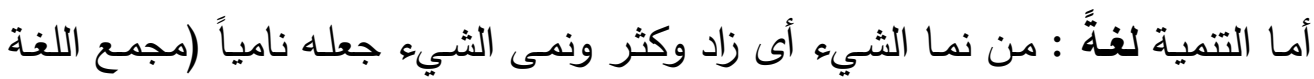

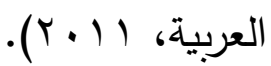
واصطلاحاً هي: رفع مستوى أداء الطلاب فى مواقف تعليمية/تعلمية مختلفة, وتتحدد التتمية على سبيل المثال بزيادة متوسط الدرجات التى يحصلون عليها بعد تدريبهم على برنامج

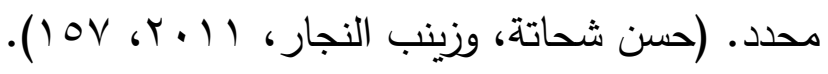
وفي هذا المحور نتتاول ماهية التتمية البشرية وعلاقتها بالتربية والتعليم، ونلك في ضوه ما ما يلي:

\section{1- مفهوم التنمية البشرية:}

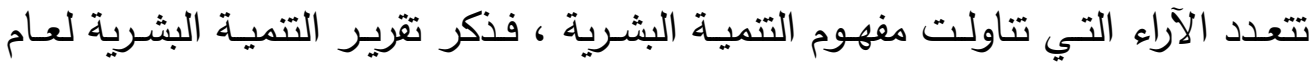

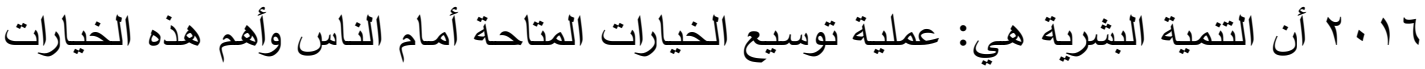
تحقيق حياة طويلة خالية من العلل واكتساب المعرفة والتمتع بمعيشة كريمة (البرنامج الإنمائي

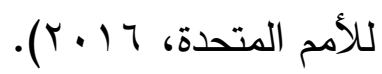

وهى كذلك عملية زيادة الخيارات أمسام الأفراد الذين يمثلون الثروة الحقيقية للأمم

.(Nadar, F, 2010)

والتتمية البشرية أيضا هي تأمين فرص الحياة لأجيال المستقبل وذلك يجعل الغرض الرئيس من عملية التتمية هو توفير بيئة يمكن للجميع فيها أن يعيشوا ويتمتعوا بحياة طويلة وصحية. (United Nations, 2017)

ومن خلال العرض السابق لمفاهيم التتمية البشرية يتضح أن جميعها تثير إلى استدامة

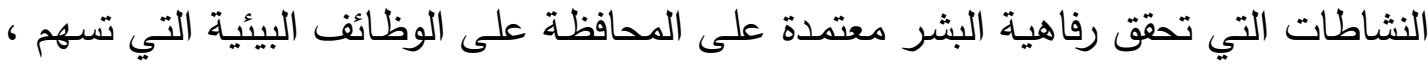


هي ذاتها بطرق مباشرة أو غير مباشرة في تحقيق رفاهية البشر، كما تشير إلى قدرة العمليات

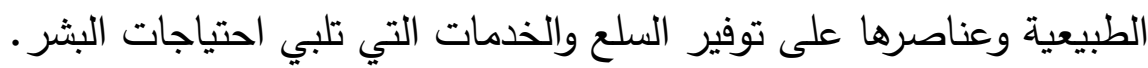

\section{r العوامل المؤثرة في تصقية التنمية البشرية :}

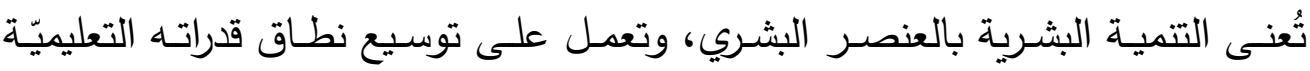
وتتمية خبراته وتطويرها، وتسعى هذه العملية للارتقاء بالإنسان ورفع مستواه من خـلال بذله

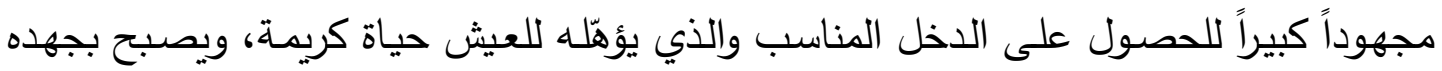

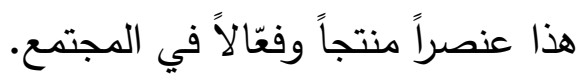
وتوجد العديد من العوامل التي ترتبط بثكل مباشر بمعايير التنمية البشرية، وتعمل على في التحاع

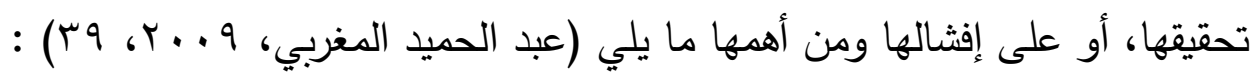

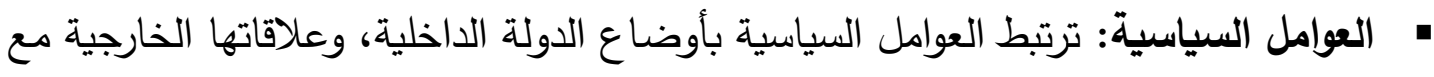

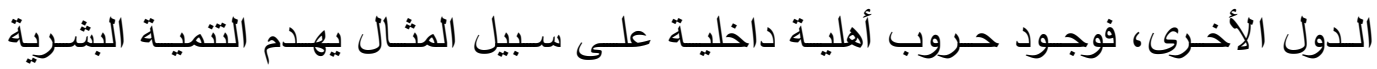

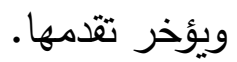

• العوامسل الاقتصـادية: يعتبر الاقتصـاد العامل الأساسي الأول في تحقيق معايير التتميـة

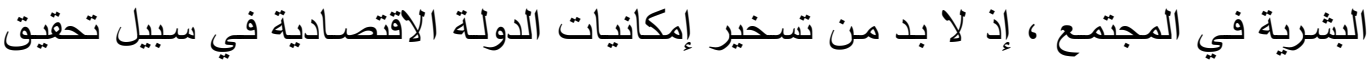

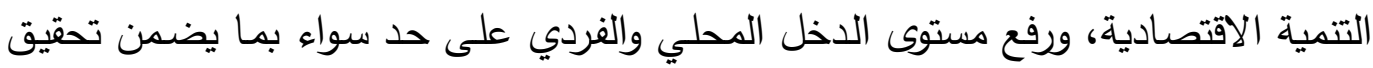
الرفاهية للسكان لاحقاً.

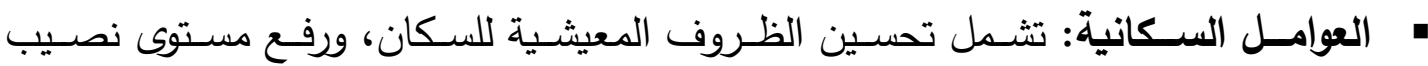
الفرد من الغذاء.

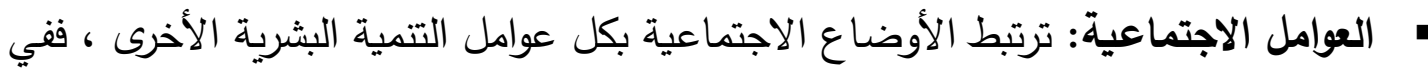
حين ترتبط العوامل الاجتماعية بتحسين العلاقات الاجتماعية بين السكان ، وخلق أدوار

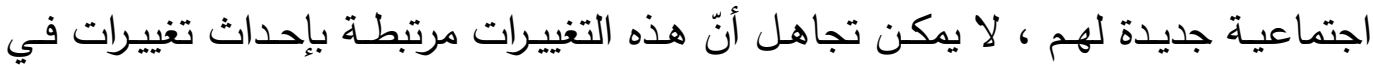

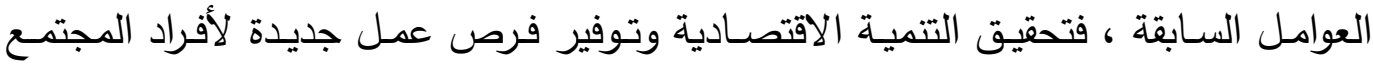

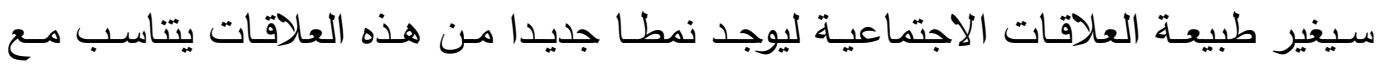

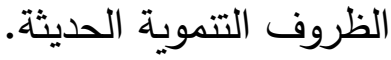
• العوامل الصحية: تعبر الأوضاع الصحية عن تطور المجال الطبي، والصحي للدولة بما يحقق تحسنا على الأوضاع الصحية للسكان. 
• العوامسل النفسية: إن تحقيق عوامل التتميـة السـابقة كلها بطريقة إيجابيـة يحسن الحالـة النفسية لأفراد المجتمع وتحقيق الرفاهية لهم.

وعلى ذلك فإن لتلك العوامل ارتباطا كبيرا بتحقيق معايير التنمية البشرية والعكس ،

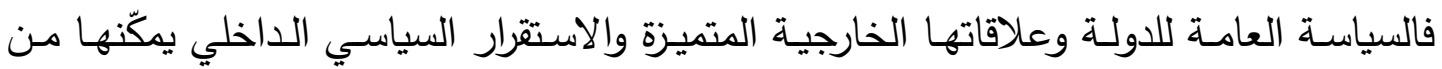

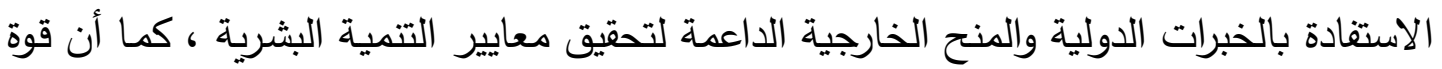

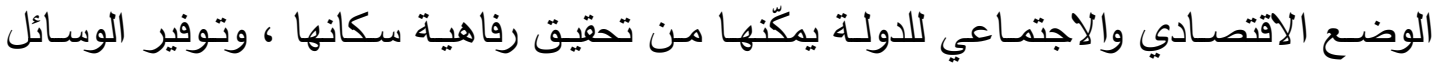
المعينة - من غذاء صحي، وتعليم جيد، وتوفير خدمات صحية على مستوى عال ، وإيجاد

فرص عمل مناسبة للشباب والعاطلين.. وغير ذلك - لتحقيق المعايير الدولية والالتزام بها.

\section{"• - العلاقة بيز التنمية البشرية والتربية والتعليم:}

شـهد النظام التربوي في نهايـة القرن الماضـي وبدايـة القرن الحـادي والعشرين تغيـرا

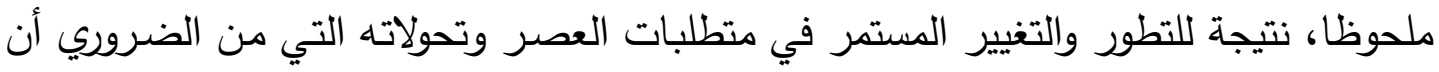

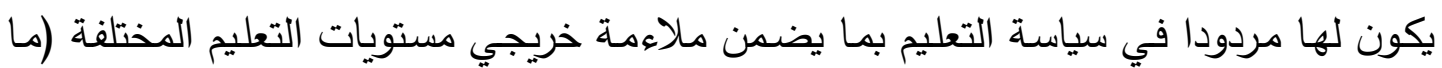
قبل الجامعي، والجامعي) لسوق العمل. وبمـا أن التعليم قد أصبح مطالبا بالعهل على تحقيق الاستثمار أو التنمية البشرية

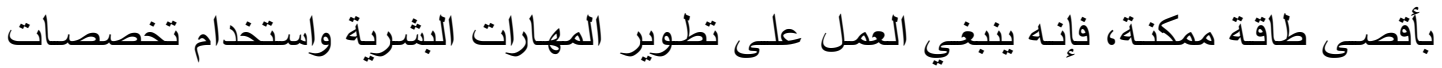
تواكب متطلبات القرن الحادي والعشرين مع الحرص على ضرورة تخريج كوادر بشرية تمتلك القدرة وتلك المهارة اللازمـة للتعامل مـع المتغيرات والمستجدات التي تشهـها مهارات القرن الحادي والعشرين حيث تفرض هذه المهارات على المناهج ضرورة التحديث المستمر لمحتواها،

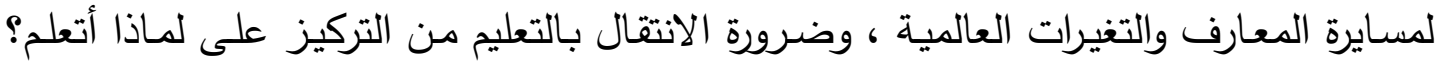

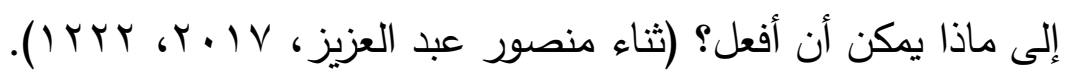

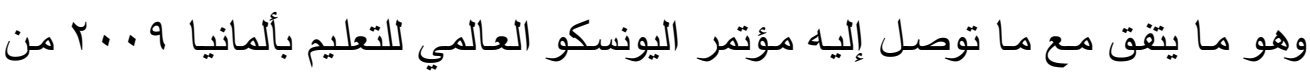

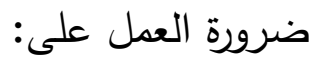

الاهتمام بالتعليم ؛ حيث يعتبر العامل الحاسم لتحسين رفاهية المجتمع وتقدمه. توفير تعليم يسمح باكتساب مهارات القرن الحادي والعشرين للمتعلمين.

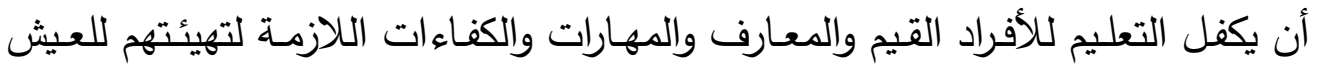

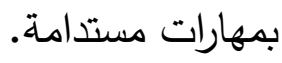


• حشد الطاقات واستغلال كل الفرص المتاحة لتحسين كل أثكال الحياة وأساليب العمل.

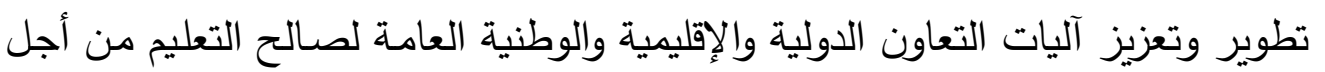
التنمية المستدامة والتي تحترم التنوع الثقافي.

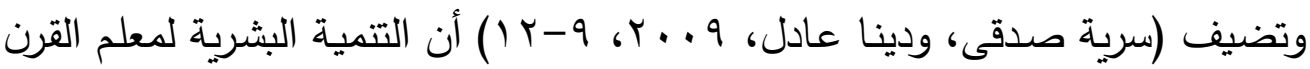

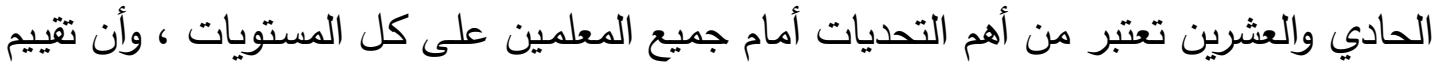
العملية التعليمية يقوم على قياس مدى إلمام المعلم بمعلومات المادة ومهارات التعلم والتفكير

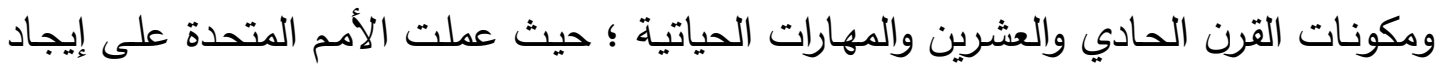
تربية تستطيع أن تواجه تحديات سوق العمل ، وقد تضافرت جهودها مـع اليونسكو لإصـلاح

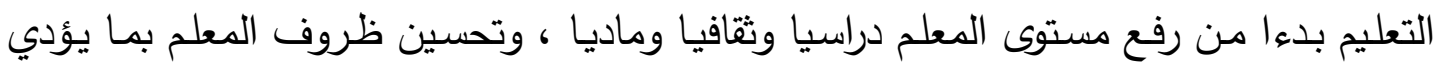

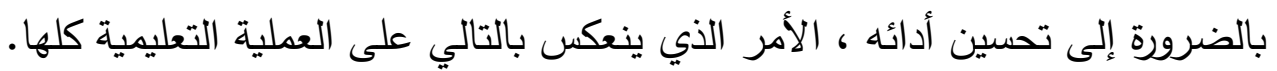

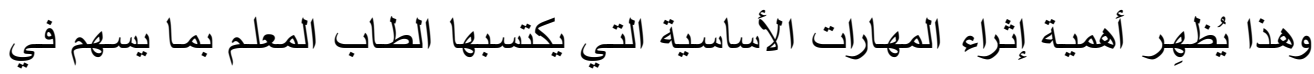

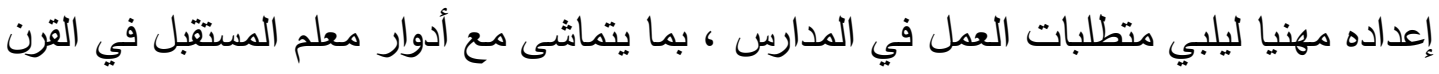

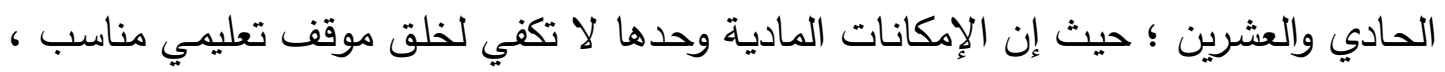

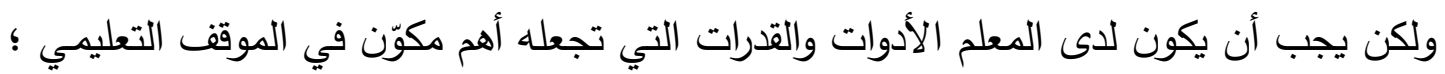

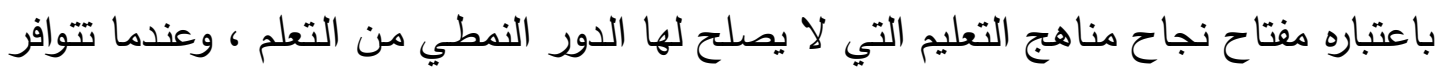
لايه تلك القدرات والأدوات يكون كالممثل الذي يتقص الديج الدور الملائم عندما يعمل مـع التلاميذ. وتلك الأدوار يلعبها بتلقائية وينتقيها وفق ما يراه مناسبا للموقف التعليمي.

\section{ع- معابير التنمية البشرية المتعلقة بالإعداد المهنيي للطالب المعلم:}

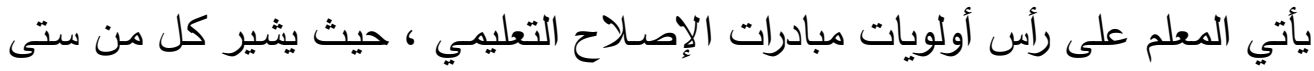

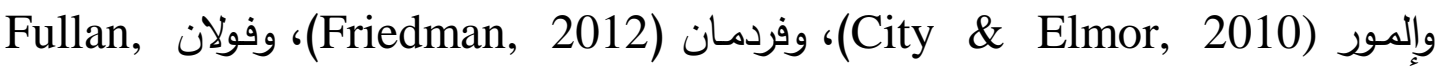
(2011) إلى أن أي مشروع لإصـلاح الددرسة ينبغي أن يركز على التتمية الثـاملة للمعلمين

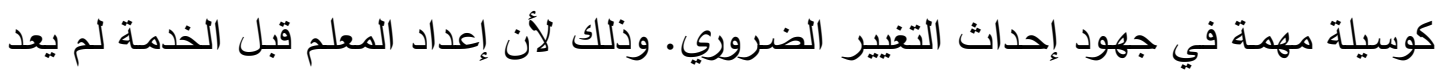

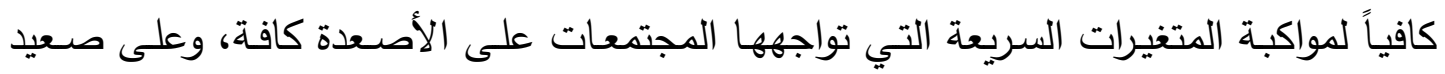

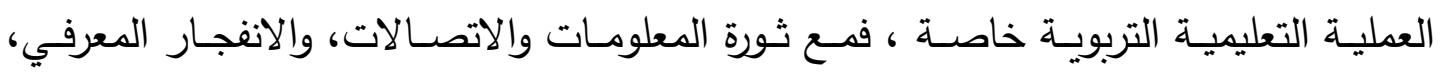

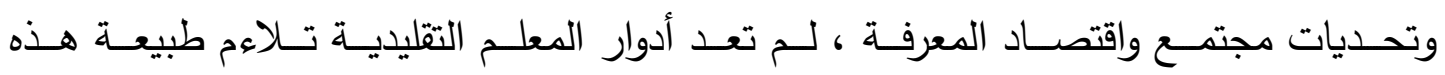

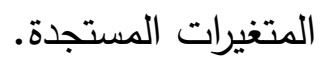


ويأتي التحول إلى مفهوم التتمية البشرية للمعلم ، حتى يواكب المستجدات في تخصصه

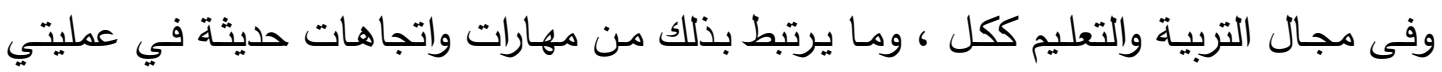
التعليم والتعلم ، ويكون المعلم في حالة تعلم دائم ، وعملية نمو مستمرة ومتواصلة ، وهو ما لاس

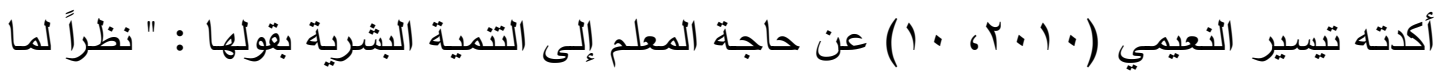

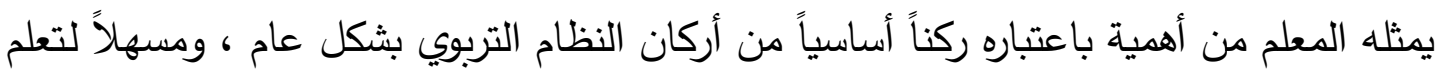

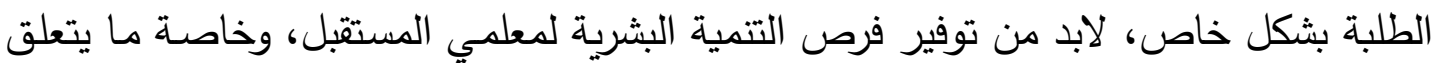

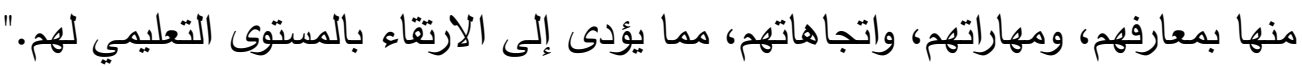

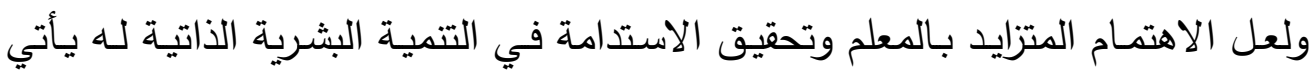

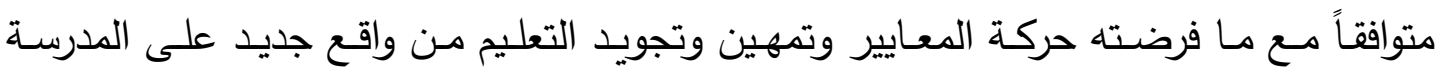

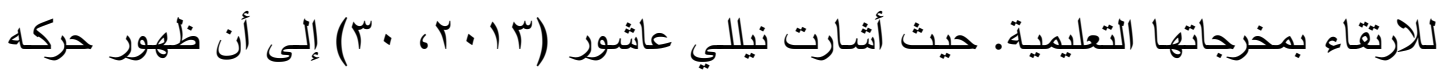

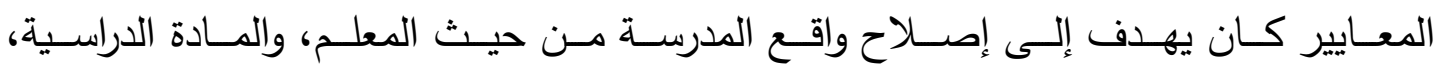

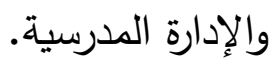

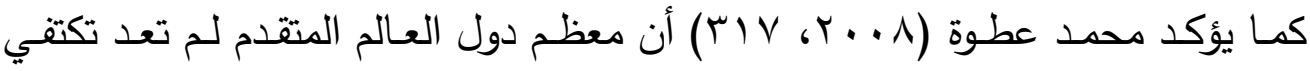

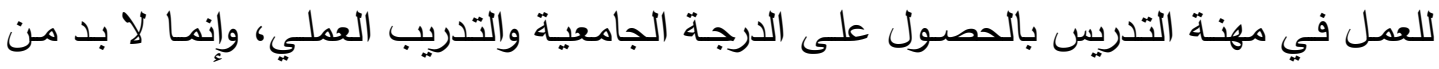

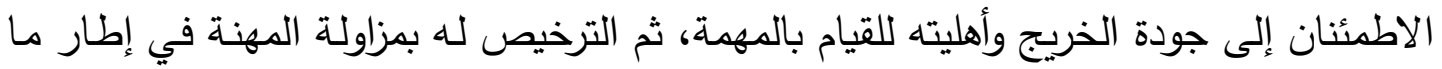

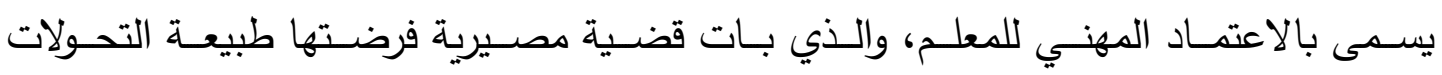
والتطورات المتسارعة.

وبالنظر للأنظمة التعليمية المتميزة حول العالم والتي حققت مخرجاتها التعليمية تفوقاً

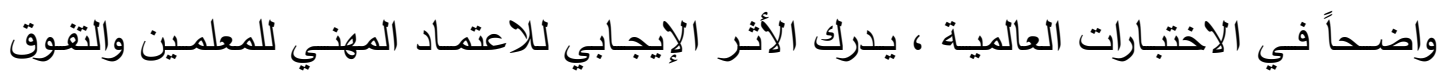

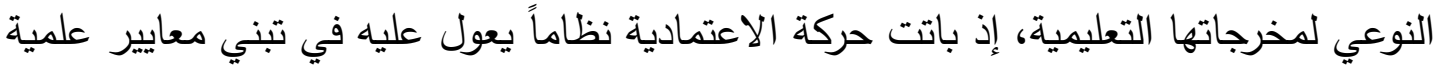

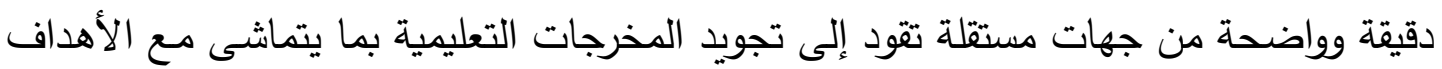

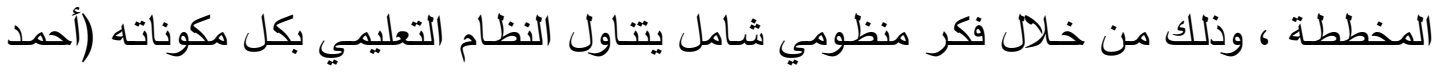

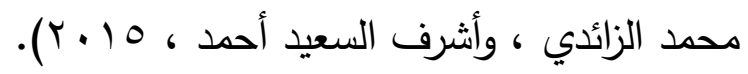
وفى ضـوء التوجها نحو الاعتمـاد المهني للمعلم ، والسعي لإصدار ترخيص لمزاولـة

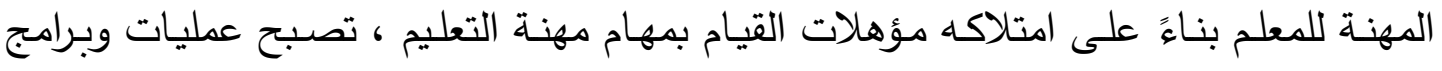
التتمية المستدامة موجهة بمعايير الاعتماد المهني للمعلم ، وبمتطلبات الترخيص لمزاولة المهنة. 
وهذا يتطلب أن يتوافر في المعلم عدد من معايير الأداء المهني بحيث يتمكن من

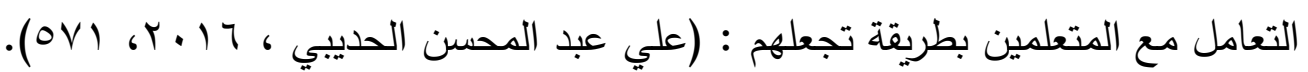
• يقبلون على التعلم ، ومؤسساته. هحققون نواتج التعلم المطلوبة منهم في مجالاتها المختلفة. يمترفون كيف يتعلمون؟. يتعاملون مع المحتوى الورقي والإلكتروني بكفاءة. يطبقون ما يتعلمونه في الحياة بطريقة سهلة. يثقون في نتائجهم التي حصلوا عليها.

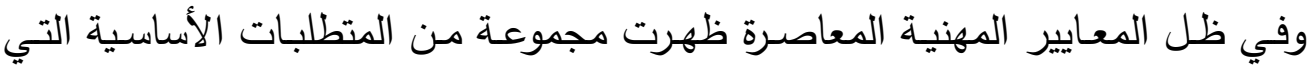

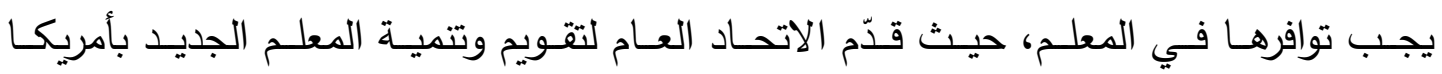

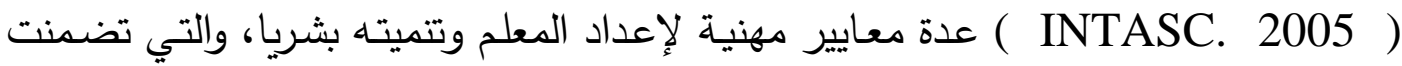

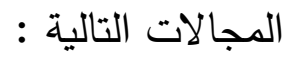

معرفة المحتوى: يتمكن المعلم من المادة العلمية التي يدرسها. • تعـم ونمـو الطالب: يراعي المعلم تتميـة الجوانب الثخصـية والاجتماعيـة والثقافيـة

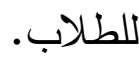
• تنوع الطلاب: يراعي المعلم الفروق الفردية بين الطلاب وأساليب تعلمهم.

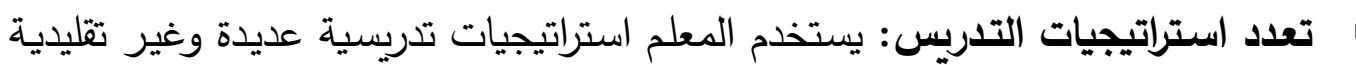
وتتماشى مع طبيعة المادة التعليمية. بيئة التعلم: يخلق المعلم بيئة تعلم فعالة وإيجابية. الاتصال: يستخدم المعلم وسائل الاتصال اللفظية وغير اللفظية، لتحقيق التفاعل النشط

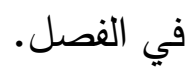
تخطيط المـنهج: يخطط المعلم للتدريس ضـوء أهداف المـنهج واحتياجـات الطـلاب والمجتمع وطبيعة المادة التعليمية. التقييم: يستخدم المعلم أساليب تقييم متتوعة ومبتكرة.

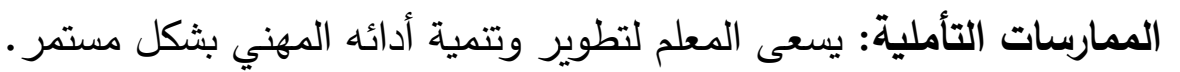
هالاندماج المجتمعي: يدعم المعلم علاقته بالطلاب والزملاء والرؤساء والآباء. 
كما حدد المجلس الوطني للمعايير المهنية في التدريس (NBPTS) بالولايات المتحدة

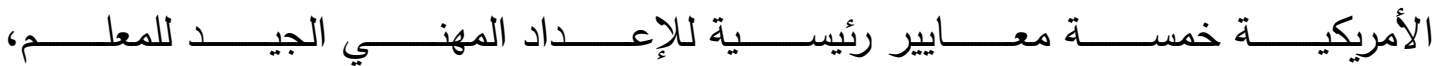
هي (United Nations, 2017): • - التزام المعلمين للطلاب وتعلمهم. - معرفة المعلمين بالمادة التي يدرسونها ومعرفة كيفية تدريسها للطلاب. • مسئولية المعلمين عن إدارة وتوجيه تعلم الطلاب. • يفكر المعلمون في ممارساتهم بشكل منظم ويتعلمون من خبراتهم. • المعلمون أعضاء في مجتمع التعلم. وفى ولاية نيويورك تم تحديد ثمانية معايير لجودة التدريس، وذلك في سبتمبر عام التطاه

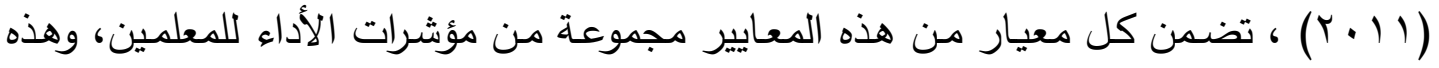

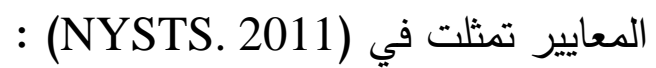

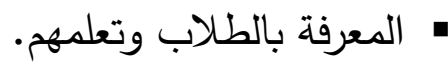
• معرفة المحتوى والتخطيط التعليمي.

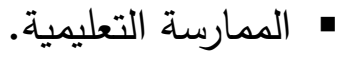

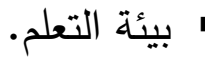
• - تقويم تعلم الطلاب. • المسئوليات المهنية والتعاون.

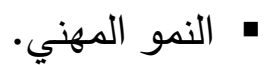

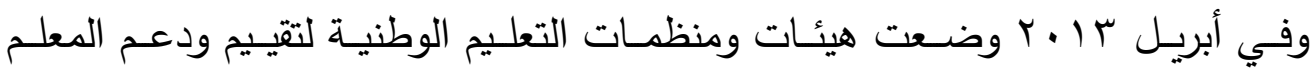
عشرة معايير للتتريس الفعال ، وليس للمعلم المبتدئ فقط ، وإنما تؤخذ كمورد للتنمية

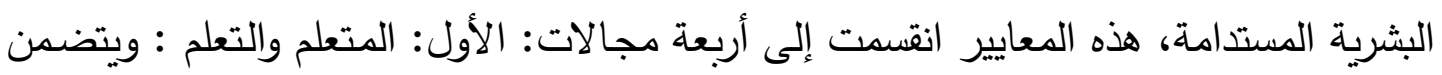

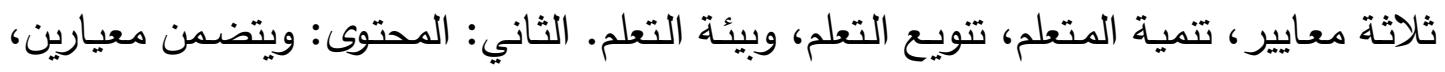
معرفـة المحتوى، تطبيق المحتوى. الثالث: الممارسـة التعليميـة: ويتضــن التقيـيم، تخطيط

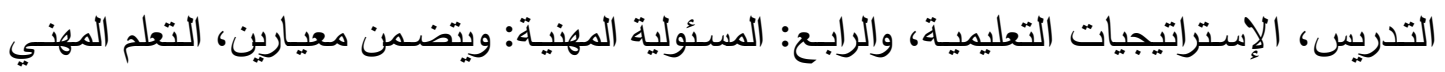
والممارسة الأخلاقية ، القيادة والتعاون (Council of Chief State School Officers, 2013). وفى المملكة المتحدة ، وضـع قسم التربيـة معـيير للمعلمين لتتيـيم جميع المتـربين للحصول على رتبة المعلم المؤهل. وتؤكد ديباجة هذه المعايير أن المعلمين يجب الندئ أن يجعلوا 
تعليم تلاميذهم هو اهتمامهم الأول، ويكونوا محاسبين عن تحقيق أعلى المعايير المككنة في

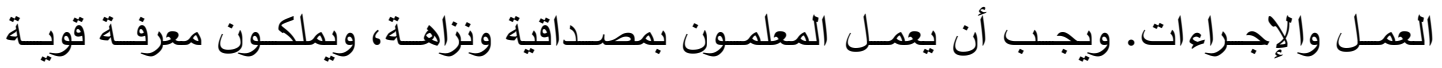
بتخصصـاتهم ، والحفاظ على معـارفهم ومهاراتهم محدَّثة وعصرية ، ولديهم القدرة على نقد

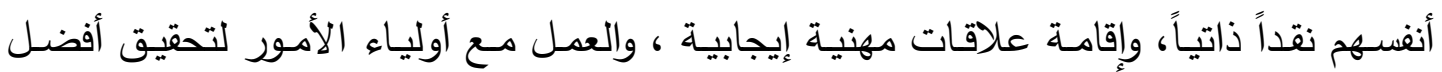
مصالح تلاميذهم. وتمثلت هذه المعايير ، في الآتي (Department of Education, 2013):

$$
\begin{aligned}
& \text { • وضع التوقعات العليا التي تحفز وتثير دافعية الطلاب وتتحداهم. } \\
& \text { • التقدم الإيجابي ومخرجات تعلم الطلاب. }
\end{aligned}
$$

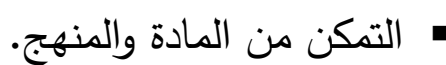

$$
\begin{aligned}
& \text { " تخطيط وتدرس دروس معدة ومنظمة جيداً. } \\
& \text { • تكييف التدريس بما يتلاءم مع قدرات واحتياجات الطلاب. } \\
& \text { " الاستفادة الدقيقة والمثمرة من التقويم. }
\end{aligned}
$$

" إدارة السلوك بفاعلية للمحافظة على بيئة تعلم جيدة وآمنة.

وانسجاماً مـع التوجهات العالمية نحو الاهتمام بالتتمية البشرية المبنية على التهائه المعايير حددت معايير الهيئة القومية للاعتماد وضمان الجودة بمصر ثمانية عشر معيارا في مجال المعلم، كما يلي (الكيئة القومية لضمان جودة التعليم والاعتماد، 9 9. . ب) :

\section{المجال الأول: مجال التخطيط:}

• تحديد الاحتياجات التعليمية للتلاميذ.

• التخطيط لأهداف كبرى وليس لمعلومات تفصيلية.

• تصميم الأنشطة التعليمية الملائمة.

\section{المجال الثاني: مجال استراتيجيات التعلم وإدارة الفصل:}

• استخدام استراتيجيات تعليمية استجابة لحاجات التلاميذ.

$$
\text { • تيسير خبرات التعلم الفعال. }
$$

- إشراك التلاميذ في حل المشكلات والتفكير الناقد والإبداعي.

$$
\text { • توفير مناخ ميسر للعدالة. }
$$

• الاستخدام الفعال لأساليب متتوعة لإثارة دافعية المتعلمين. • إدارة وقت التعلم بكفاءة والحد من الوقت الفاقد. 


\section{المجال الثالث : مجال المادة العلمية :}

• التمكن من بنية المادة العلمية وفهم طبيعتها • التمكن من طرق البحث في المادة العلمية. • ت تمكن المعلم من تكامل مادته العلمية مع المواد الأخرى.

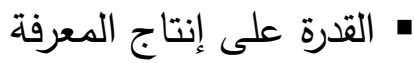
المجال الرابر: مجال النقوبيم:

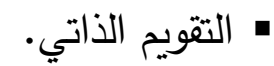
• - تقويم التلاميذ.

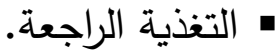

المجال الذامسر: مجال مهنية المعلم:

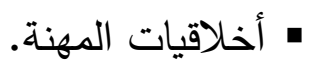

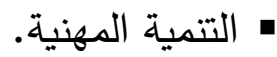

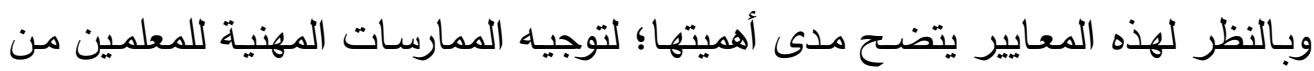

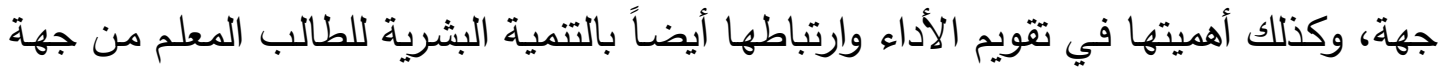
أخرى، وأهية تعلم المعلم وتطوره المستمر في سبيل الإعداد المهني وأهليته بالبقاء في المهنة ومزاولتها (أحمد محمد الزائدي، وأشرف السعيد أحمد، 10 • ب).

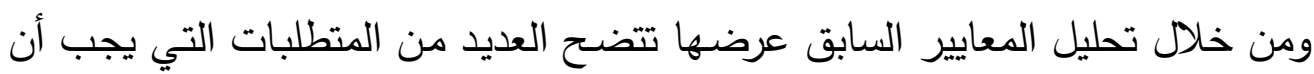

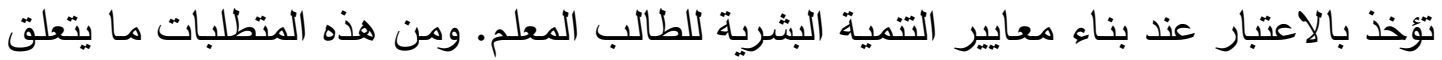
بالمجال المعرفي لتخصص المعلم ، حيث يجب أن يكون المعلم على دراية بمحتوى المـادة

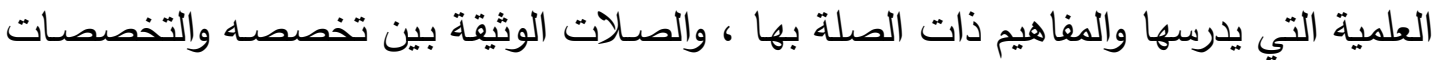

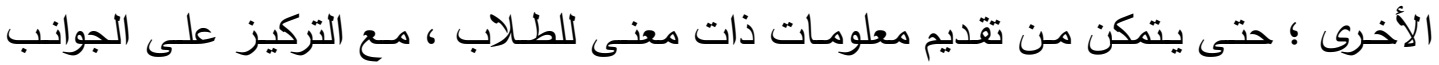
التطبيقية من هذه المعارف. وتأسيسا على كل ما سبق تقترح الدراسة الراهنة معايير التتمية البشرية المتعلقة بالإعداد

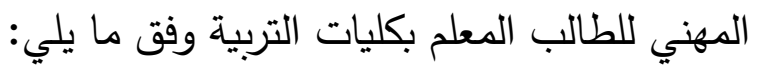
- المعيار الأول: يلم بالمعارف اللازمة لتخصصسه العلمي شاملةً خصائص العلم ومبادئه ومفاهيمه، ويتفهم المنهج الدراسي وأسسه وعناصره بما يمكنه من التعامل معه بصورة تحقق الأهداف التعليمية. 
• المعيار الثاني: يخطط دروسه بطريقة علمية.

• المعيـار الثالث: يوظف طرائق وأسـاليب تدريس متتوعـة تتوافق مـع عناصـر عمليـة التعلم، وتحقق أهدافها.

• المعيار الرابع: يستخدم مهارات الاتصال اللفظية وغير اللفظية بما يسهل عملية التعلم.

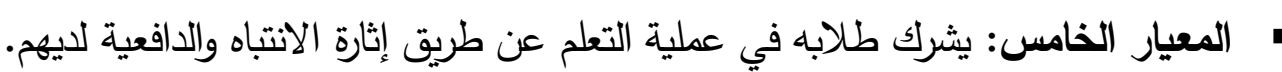
هالمعيار السادس: يعمل على تتمية شخصية الطالب وتطوير تنكيره وإكسابه المهارات

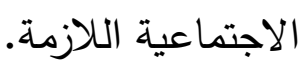

المعيـار السـابع: يدير الصف الدراسي وينظم ويرتب عناصـره ويعالج الأخطاء فيها بطريقة تساعد على زيادة تحصيل المتعلمين وتنمية ذواتهم. • المعيار الثامن: يعد الوسائل والتقنيات التعليمية ويستخدها في دروسه فيزيد من فاعلية التعلم.

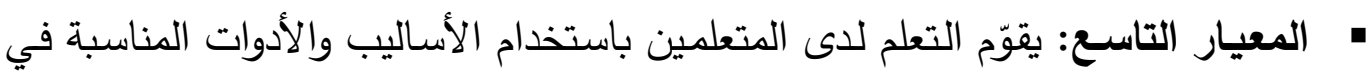

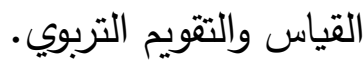

" المعيار العاشر: يسهم بإيجابية في الأنشطة المتنوعة التي تتفذها المدرسة.

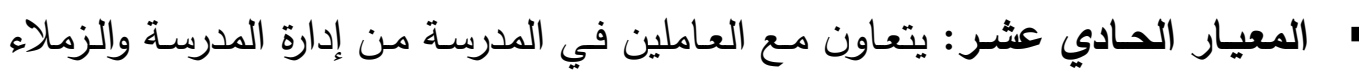
والمشرف التربوي بما يحقق روح الفريق. " المعيار الثاني عشر: يعمل على تطوير نفسه مهنياً. إجــراءات الدراسـة الميدانيــة: لتطبيق الدراسة الميدانية قام الباحثان بمجموعة من الإجراءات، وهى على النحو التالي:

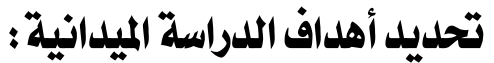

تهدف الدراسة الميدانية الحالية إلى الإجابة عن التساؤلات التالية والموجهة إلى عينة الدراسة من الطلبة المعلمين بكليتي التربية بجامعتي أسيوط والسادات: س ا: ما الترتيب المناسب لمعايير التمية البشرية من وجهة نظرك ؟ س ץ: ما درجة توفر مؤشرات كل معيار من المعايير لديك ؟ مان

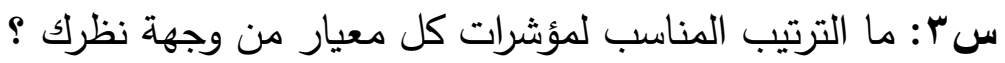




\section{تحلديل مجتمع اللدراسة وعينته :}

تم اختيار عينة الدراسة بالطريقة العشوائية من طلبة الفرقتين الثالثة والرابعة بكلية التربية عام وطفولة وتعليم أساسي ، بجامعتي أسيوط والسادات ؛ كعينة ممثلة لمجتمع الدراسة في العام

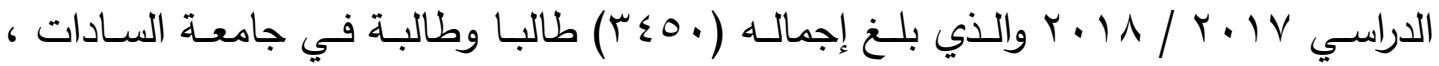

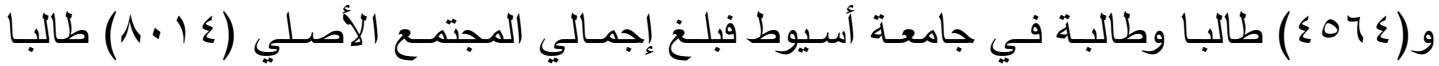

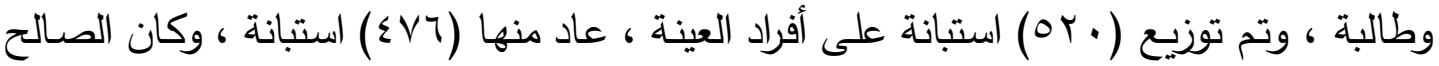
منها لأغراض البحث العلمي (0 (ع) استبانة ، والجدول( () التالي يبين توزيع أفراد العينة :

جلدول (1)

\section{توزيع أفراد العينة وققا لمتفيرات الدراسة}

\begin{tabular}{|c|c|c|c|c|}
\hline النسبة \% & العدد & بالدراسة & & A \\
\hline$r v, r$ & 100 & التربية عام & \multirow{3}{*}{ الكلية } & \multirow{3}{*}{1} \\
\hline rr & lir & طفولة & & \\
\hline ro,r & $1 \leqslant \wedge$ & تعليه أساسي & & \\
\hline$\xi \Lambda, r$ & r.. & الثالثة & \multirow{2}{*}{ الفرقة } & \multirow{2}{*}{$r$} \\
\hline 01,1 & rio & الرابعة & & \\
\hline$r \cdot, v$ & 17 & ذكر & \multirow{2}{*}{ الجنس } & \\
\hline vq, r & rrq & أنثى & & \\
\hline 1... & $\$ 10$ & \multicolumn{2}{|c|}{ 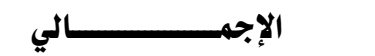 } & \\
\hline
\end{tabular}

على ضـوء الجدول (1) السـابق يتضـح وجود غلبة فيما يتعلق بتمثيل فئة الإناث عن

فئة الذكور في متغير الجنس ، ويعود ذلك لكثرة الملتحقات من البنات بكلية التربية وأقسامها ، كما يتضح زيادة أفراد العينـة من الفرقة الرابعة عنها في الفرقة الثالثة ؛ ربما لأن طلاب الفرقة الرابعة باتوا الأقرب نحو الممارسة الفعلية لمهنة التدريس ، كما أنهم نالوا قسطا أكبر من البرامج التعليمية والتربية العملي.

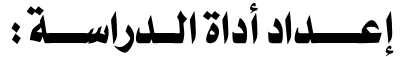

قام الباحثان بينـاء وتطوير استبانة بغية تعرُّف واقع الإعداد المهني للطالب المعلم بجامعتي أسيوط والسادات في ضوء معايير التتمية البشرية، من وجهة نظر الطلبة/المعلمين 
بكلية التربية عام وطفولة وتعليم أساسي، من خلال دراسة الأدب التربوي والدراسات السابقة،

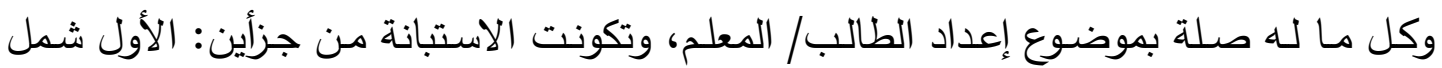

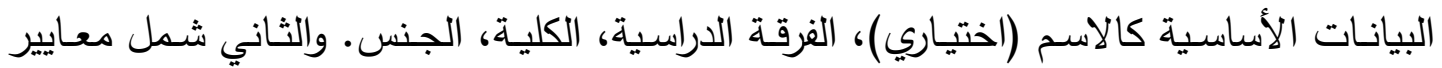

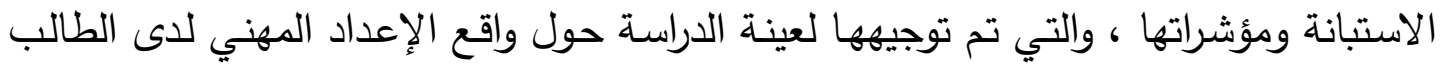

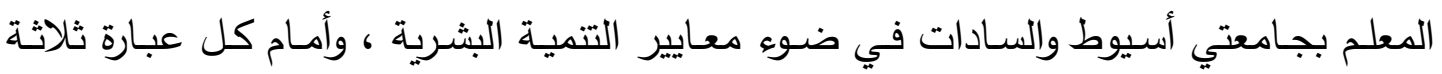
مستويات تقيس درجة توافر معايير الاستبانة لاى أفراد العينة ، وهي : متوفر (ثلاث درجات التهات) ،

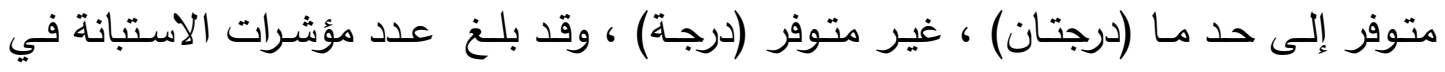

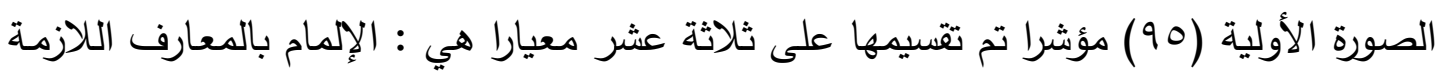

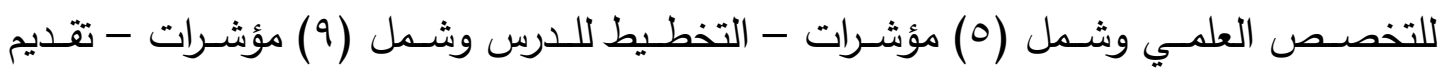

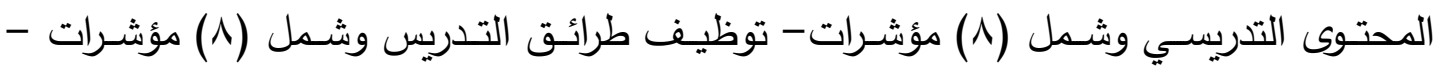

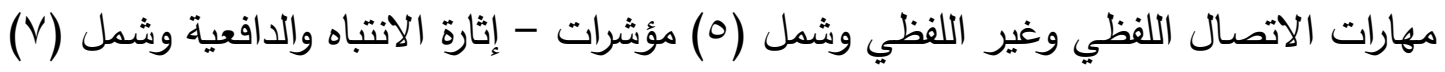

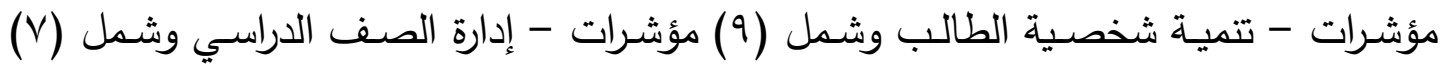

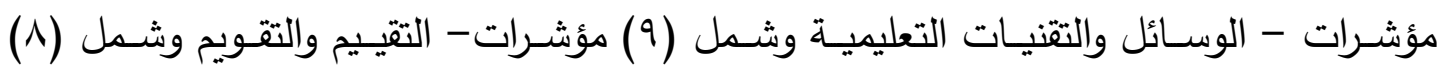

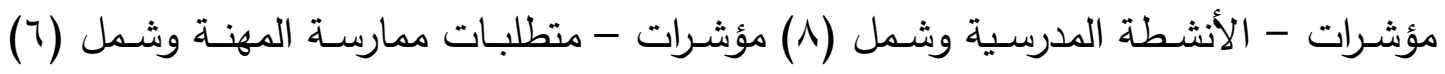
مؤشرات - التتمية المهنية الذاتية وشمل (†) مؤشرات".

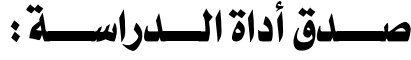

ثمـة طرق كثيرة لقياس صدق الأداة ، إلا أنَّ الدراسة الحالية اعتمدت في حسابه على

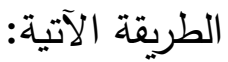

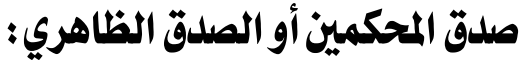

حيث قام الباحثان بعرض الاستبانة في صورتها الأولية على (• ( ) من السادة الخبراء

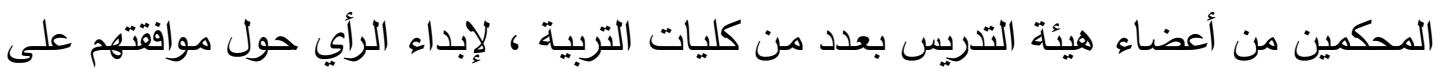

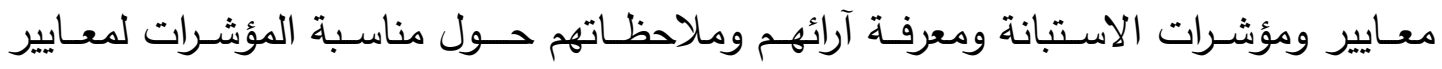

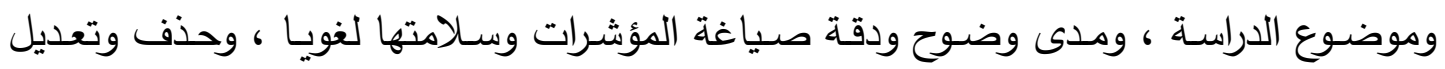

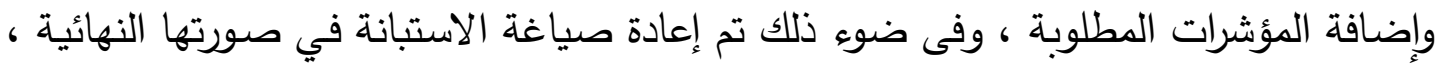

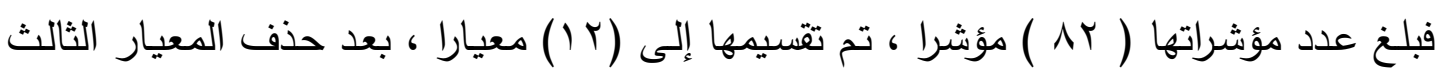
لأنه متضمن في باقي المعايير. 


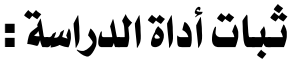

تم حساب الثبات بطريقة إعـادة الاختبار ( Test - Re- test )، حيث تم توزيع الاستبانة على عينـة استطلاعية تكونت مـن (01) مـن الطلبة المعلمين بالجـامعتين محل

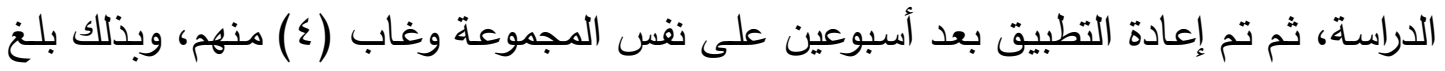
العدد (؟))، وبذلك حصل كل فرد على درجة في المرة الأولى للاختبار ودرجة في المرة الثانية للاختبار ، وبرصد الدرجات تم حساب معامل ارتباط درجات المرة الأولى بدرجات المرة الثانية

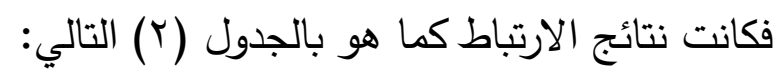

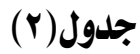

يبيز قيم معامل الثبات بين درجات التطبيق أول للاستبانة ودرجات التطبيق الثاني لها

\begin{tabular}{|c|c|c|c|c|c|c|c|}
\hline الصف & شخصية & الانثباه & مهارات & التدريس & اللخطيط & الإلتخاه بمصارف & الميار \\
\hline $\begin{array}{l}\cdot, \wedge \wedge \\
* *\end{array}$ & $* * \bullet, \wedge \uparrow$ & $* * \bullet, \wedge V$ & $* * \bullet, \vee q$ & **•, $\vee \wedge A$ & $* *, Y Y$ & $* * \bullet, Y Y$ & معامل الارتباط \\
\hline & المجموع & الذاتنية & ممارسة المهنة & مدرسية & والتققييه & والتقنيات & المعيار \\
\hline & $* *, \wedge \xi$ & $* * \bullet, Y V$ & $* * \bullet, \vee 9$ & $* *, \wedge 7$ & $* * \cdot, 79$ & ***, YO & معامل الارتباط \\
\hline
\end{tabular}

وعلى ضـوء الجدول (r) السـابق يتضـح أن معامل الثبات قد تراوحت بين

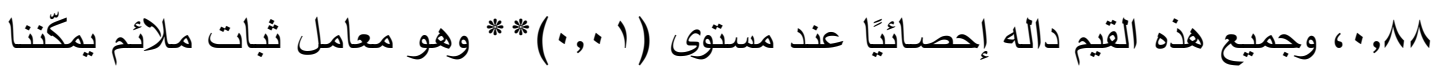
من الوثوق بالاستبانة عند التطبيق.

\section{الأساليب الإحصائية لتحليل البيانات :}

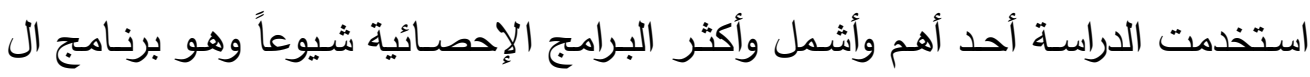

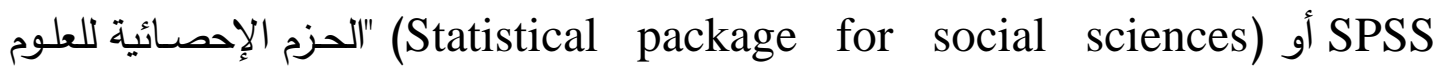

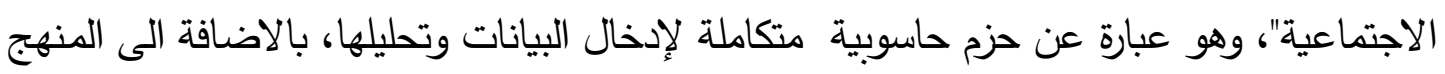

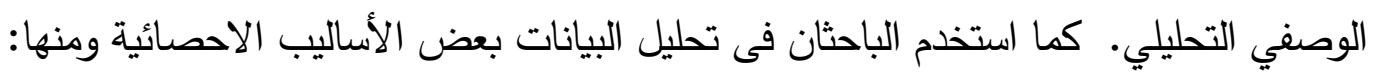

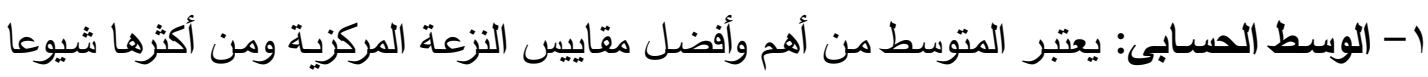

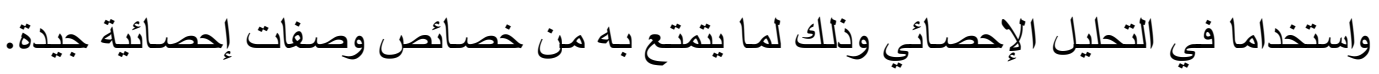

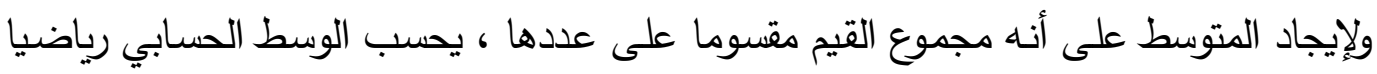
بجمع قيم عناصر المجموعة المراد إيجاد وسطها ، ويقسم المجموع على عدد العناصر. $\bar{x}=\frac{1}{n} \sum_{i=1}^{n} x_{i}=\frac{1}{n}\left(x_{1}+\cdots+x_{n}\right)$. 
r- الوزن النسبى: ويتم حساب الوزن النسبى للعبارة للتعرف على الاهمية النسبية لها بالنسبة للمحور الخاص بها وذلك لترتيب العبارات وفقا للاهية النسبية لهم ، يتم حساب الوزن

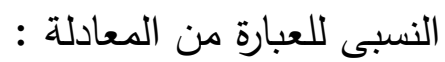

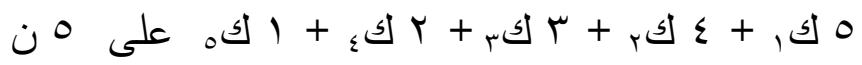

حيث : ك, = عدد التكرارات (دائما) كى = عدد التكرارات (غالبا) كى = عدد التكرارات ( أحيانا)

$$
\text { كء = عدد التكرارات (قليلا) كه = عدد التكرارات (نادرا) }
$$

ن = عدد أفراد العينة.

\section{نتائج الدراسة الميدانية وتفسيرها :}

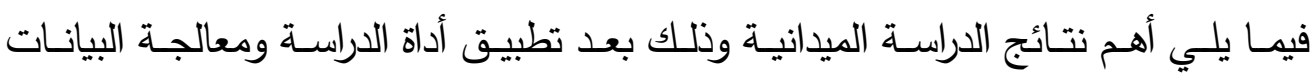

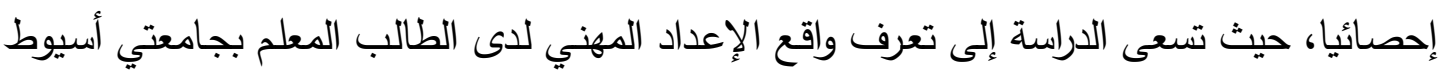

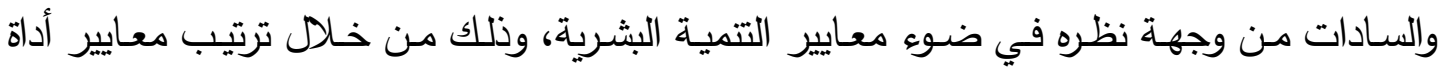

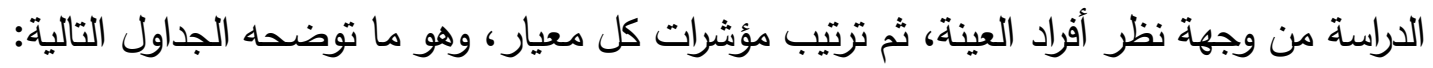

$$
\text { جلدول(r) (ז) }
$$

\begin{tabular}{|c|c|c|c|c|}
\hline الترتبب & المتوسط الحسابي & علد المؤشرات & المعيار & 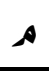 \\
\hline الثاني & $r, r r$ & 0 & الإملام بالمعارف اللازمة للتخصص & 1 \\
\hline الحادي عشر & 1,91 & 9 & التقييم والتقويم & $r$ \\
\hline 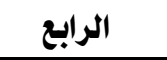 & $r, 19$ & 7 & توظيف طرائق التدريس & $r$ \\
\hline الثاني عشر & 1,19 & 0 & مهارات الاتصال اللفظي & $\varepsilon$ \\
\hline الخامس & $r, 17$ & $r$ & إثارة الانتباه والدافية & 0 \\
\hline الثامن & $r, \bullet \wedge$ & 9 & تنمية شخصية الطالب & 9 \\
\hline 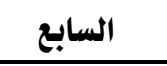 & $r, \bullet q$ & $\checkmark$ & إدارة الصف الدراسي & $\checkmark$ \\
\hline 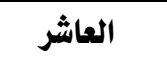 & $r$ & $\checkmark$ & الوسائل والتقنيات التعليمية & $\Lambda$ \\
\hline الأول & r,ro & $\wedge$ & التخطيط لللدرس & 9 \\
\hline السادس & $r, 1 \varepsilon$ & 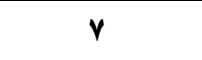 & الائشطة المدرسية & 1. \\
\hline الثالث & $r, r_{1}$ & 7 & متطلبات ممارسة المهنة & 11 \\
\hline \multirow[t]{2}{*}{ التاسع } & $r, \cdot 1$ & 7 & التنمية المهنية الذاتية & ir \\
\hline & ro,r & Ar & الإجمالـــــــــي & \\
\hline
\end{tabular}

\section{ترتيب معايير التنمية البشرية المتعقة بالإعداد المهني للطالب المعلد منوجهة نظر عينة الدراسة}


يتضح من الجدول (r) السابق أن متوسط درجات أفراد العينة حول درجة تحقق معايير

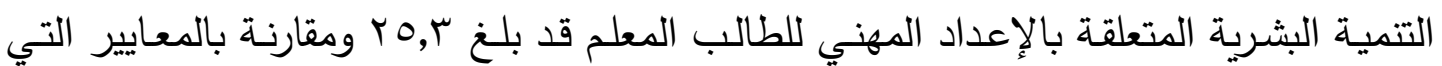

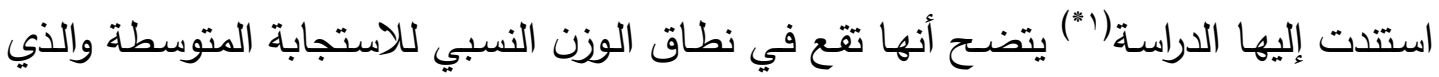

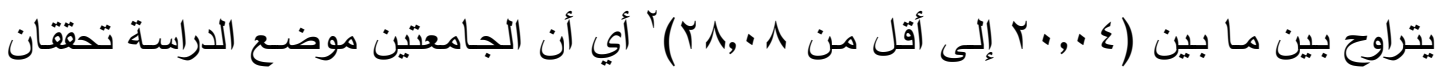

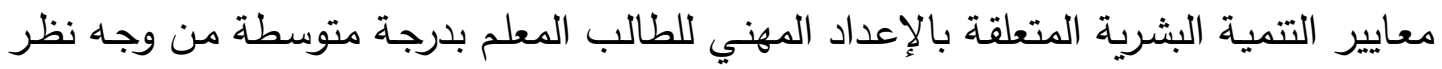

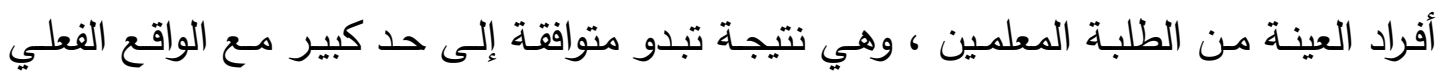

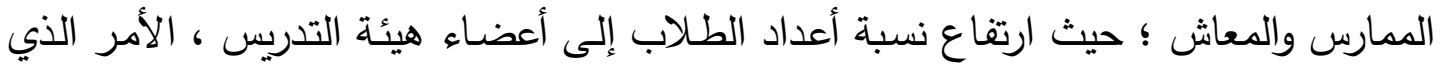

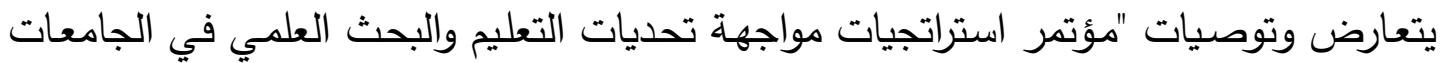

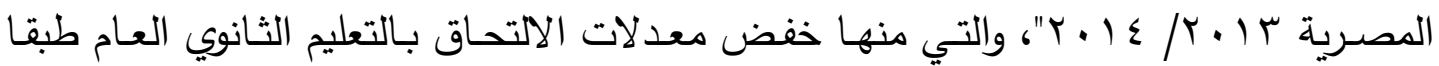

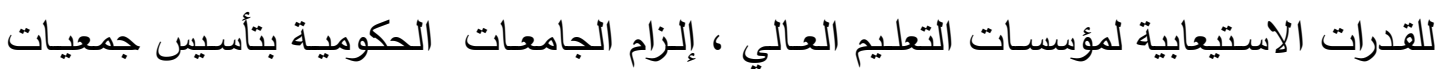

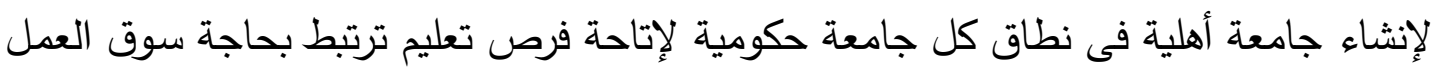

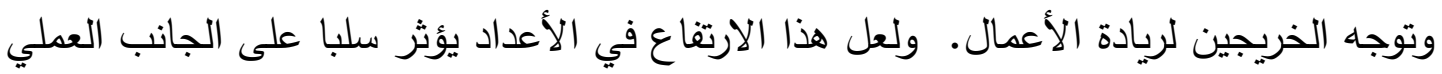

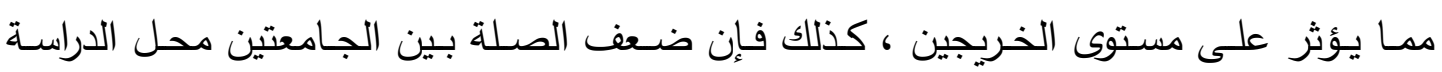

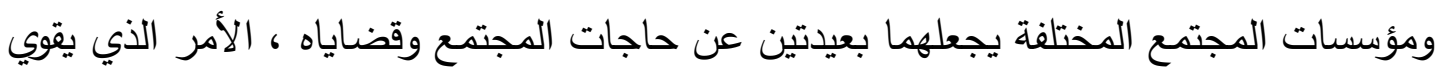

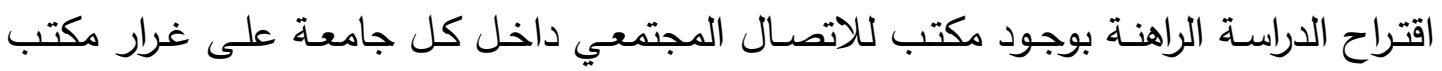

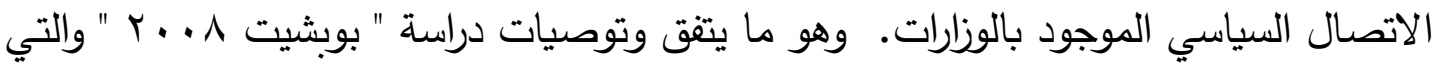
أوصت بإنشاء مركز للإنثاء والتوجيه في الكلية وتعزيزه بذوي الخبرة من أعضاء هيئة التدريس. كذلك ربما تعود هذه النتيجة إلى قلة الاهتمام بالمكتبات

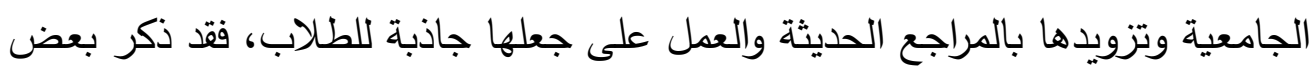
أفراد العينة أنهم لم يدخلوا المكتبة إلا مرات معدودة؛ فهي لا تفي باحتياجاتهم والبحث فيها يحتاج إلى وقت وجهد كبير بعكس محركات البحث على الإنترنت. كذلك ضعف التواصل بين

(") اعتمدت الدراسة على المعايير الآتية للحكم على درجة تحقق معايير التنمية البشرية الدتعلقة بالإعداد

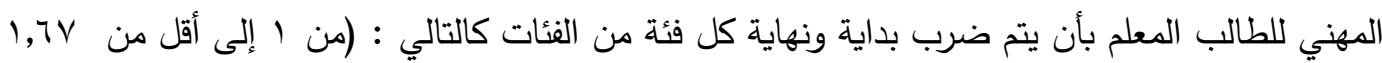

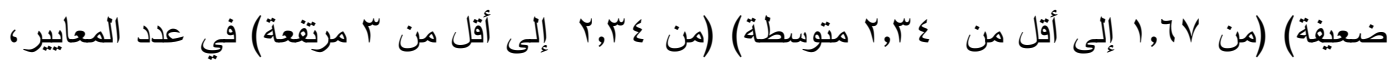

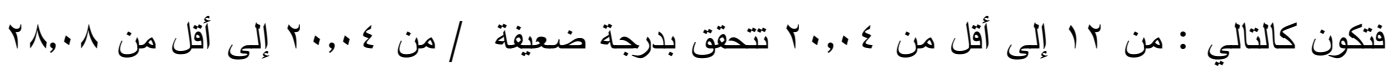

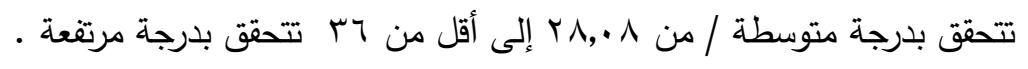


هيئة التدريس والطلاب وهو ما يتفق وتوصيات دراسة " نواف الظفيري ومحمد سعد الدين بيان

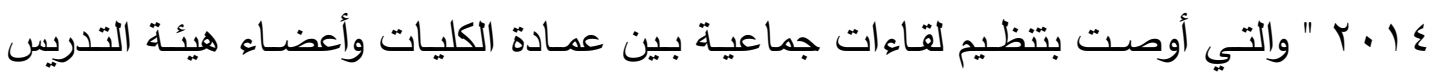
والطـلاب إعطـاء الفرصـة في المناقشـة وإبـاء الرأي حول دراستهم. إضـافة إلى أن المنـاهج

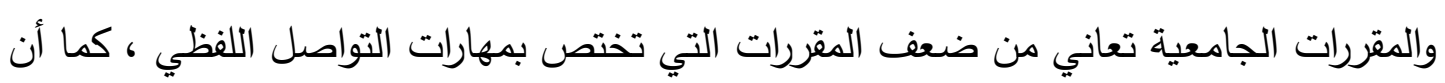
الطرق المستخدمة في التقويم يغلب عليها التقليدية والنمطية ، مع ضعف صنف الاهتمام بالأنشطة الطلابية ، فضلا عن ضعف خدمات المرافق ، وقلة الموارد والإمكانات المادية. وهو ما يتفق

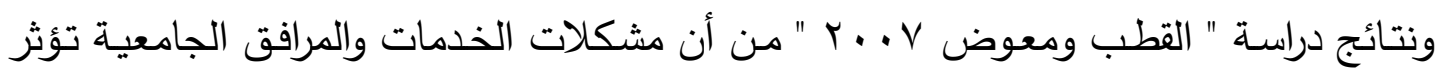
على التحصيل العلمي لطلاب الجامعة. • كما يتضـح من الجدول (ץ) السـابق أيضـا أن معيار "التخطيط للدرس " قد احتل المرتبـة الأولي فيما يتعلق بترتيب معايير أداة الدراسة من وجهة نظر أفراد عينة الدراسة بمتوسط حسابي قدره (r.ror). وقد يعود ذلك إلى أن ثمة جهودا حقيقية تبذلها الجامعتان لتجويد

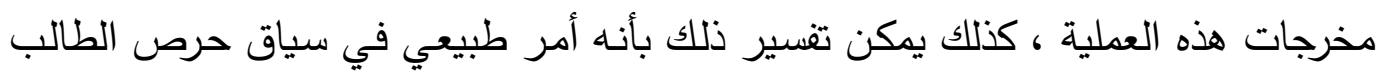
المعلم على الاهتمام بعنصر التخطيط عند إعداد الدرس ـ وإلا فإنه سيجد نفسه في حجرة الدرس مشتت الفكر مفرق النفس لا يدري بماذا يبدأ ، ولا كيف سينهي درسه. وهذه النتيجة

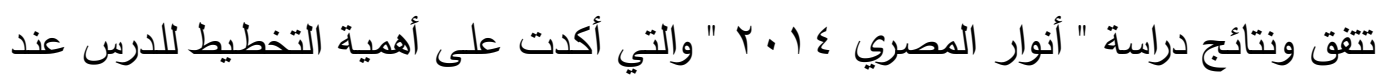

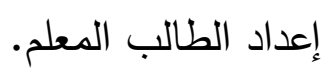
• في حين جاء معيار " الإلمام بالمعارف اللازمـة للتخصص " في المرتبة الثانية بالنسبة

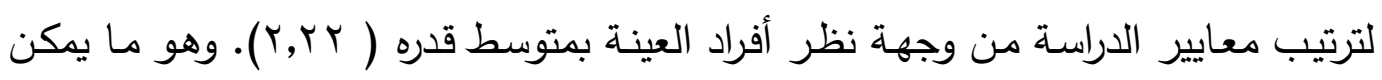
تفسيره في ظل حرص كليات التربية عموما على إكساب أبنائها المعارف الرئيسة للتخصص

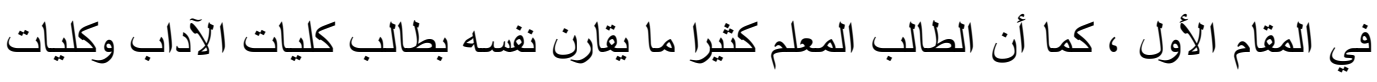
العلوم في الكم المعرفي في التخصص. وهو الأمر الذي يعزز النتيجة السابقة والمتمثلة في

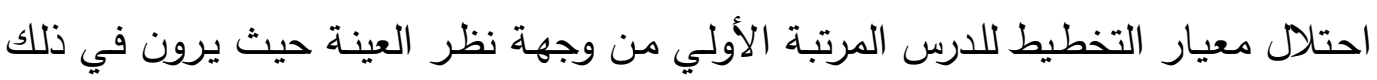

$$
\text { المعيار تميزا على طلاب كليات الآداب وكليات العلوم. }
$$
وفي المرتبة الأخيرة جاء معيار " مهارات الاتصـال اللفظي " بمتوسط قدره (9,^, () وذلك الك 
من وجهة نظر العينة. وهو الأمر الذي يمكن تبريره في ظل الأعداد الضخمة للطلاب بكليات التربية لارجة تصل إلى عدم استيعاب المدرج للطلبة ، الأمر الذي يعوق حدوث التواصل اللفظي بين الطالب المعلم وأستاذه الجامعي ، فكيف إذا يتعلم مهارات التواصل

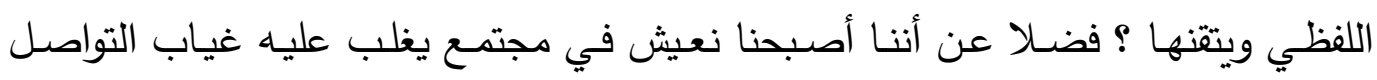

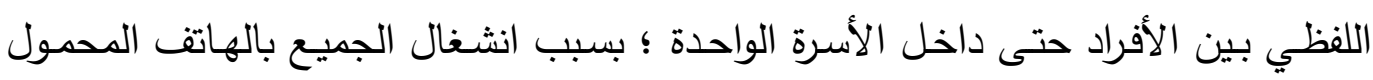

ومواقع التواصل الاجتماعي ، فالكثيرون متقاربون جسديا ، متباعدون ذهنيا ونفسيا.

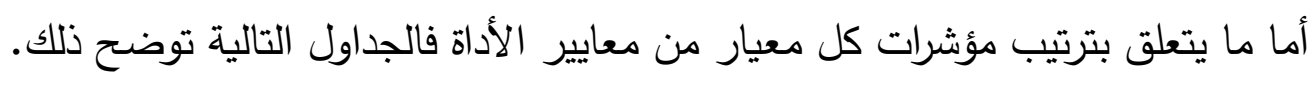

$$
\text { جدول(₹) }
$$

ترتيب ودرجة توفر مؤشرات معيار الإمام بالمعارف اللازمة للتخصص من وجهة نظر العينة

\begin{tabular}{|c|c|c|c|c|c|c|c|c|c|c|}
\hline \multirow{2}{*}{ الترتيب } & \multirow{2}{*}{ النسبي } & \multirow{2}{*}{ المتوسط } & \multicolumn{2}{|c|}{ غير متوفر } & \multicolumn{2}{|c|}{ إلى حد ما } & \multicolumn{2}{|c|}{ متوفر } & \multirow{2}{*}{ 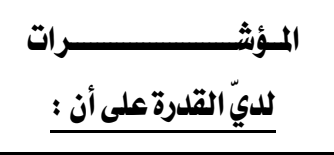 } & \\
\hline & & & $\%$ & تكرار & $\%$ & تكرار & $\%$ & تكرار & & \\
\hline 1 & •,q & $r, \wedge l$ & $\eta, r$ & rq & $\eta, r$ & rq & $\wedge \vee, \xi$ & rqr & أحلد المحتوى اللني أقوه & 1 \\
\hline$\xi$ & •, 77 & 1,91 & $r q, \&$ & 101 & $Y \wedge, q$ & ir. & $r \varepsilon, \gamma$ & $1 \xi \varepsilon$ & على مستوى المرحلة التعليمية أولنيات & $r$ \\
\hline 0 & r & 1,19 & $\$ 1,9$ & IV乏 & $r q, q$ & 11. & $r \mid, 0$ & $|r|$ & وأربط المحتوى بتوقعات الحياة & r \\
\hline$r$ & $\cdot, \wedge \cdot$ & $r, r q$ & 11 & vo & $r, r$ & 91 & $\Delta \Lambda, r$ & T\&Y & أحلد الاحتياجات التعليمية & 8 \\
\hline$r$ & •, Vr & r,IV & $\eta, r$ & rq & $79, \mathrm{~V}$ & rAq & rq & $1 \cdots$ & أستخلدم معارفي ومهاراتي في & 0 \\
\hline
\end{tabular}

جلدول (0)

مستويات معيار الإمار بالمعارف اللازمة للتخصص (0)

\begin{tabular}{|c|c|c|}
\hline النسبة \% & التكرار & المستوى \\
\hline$Y, \Lambda$ & 9. & منخفض \\
\hline rI & irq & متوسط \\
\hline$\varepsilon r, r$ & 197 & مرتفع \\
\hline 1... & $\$ 10$ & المجموع \\
\hline
\end{tabular}


يتضـح من الجدول (0) السـابق أنـه قد تم تقسيم معيـار الإلمسام بالمعـارف اللازمـة

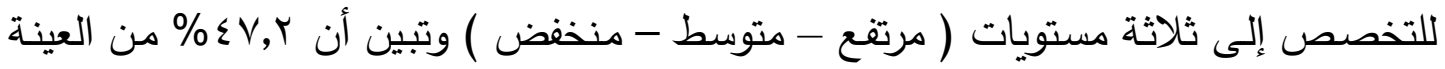
محور الدراسة تقع في المستوى المرتفع، بينما يقع إس \% في المستوى المتوسط ، في حين

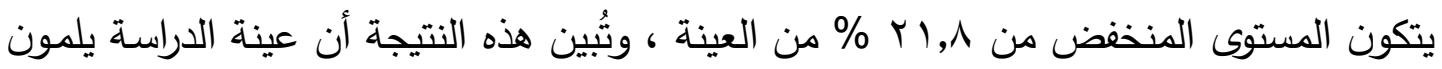
بالمعارف اللازمة للتخصص بدرجة مرتفعة ؛ وقد يرجع ذلك إلى المسئولية الفردية والجماعية التي يشعر بها الجميع تجاه معرفة وإتقان الدقررات الدراسية الواجبة ، كما تعكس هذه النتيجة الحرص على الجانب المعرفي الذي ساعد بدوره على اكتساب المعرفة بصورة وظيفية.

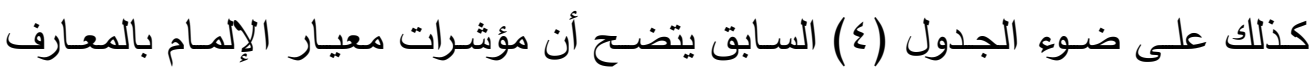

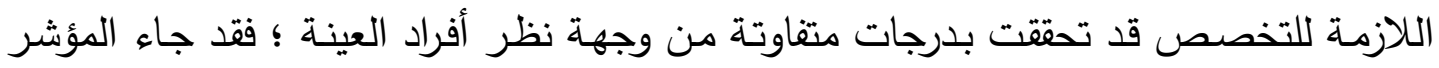
(1) والذي ينص على (أحلد المحتوى الذي أقوم بتدريسـه ) في المرتبة الأولى ، بمتوسط

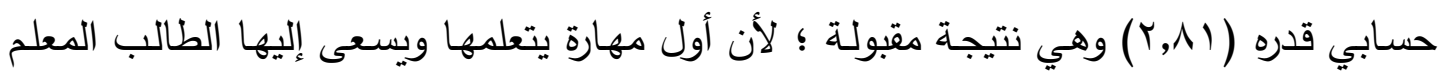
أثناء التربية العملية هي كيفية تحديد الجزء الذي سيقوم بتدريسه للتلاميذ. وقد جاء المؤشر (ع) والذي ينص على " أحدد الاحتياجات التعليمية للمتعلمين " في

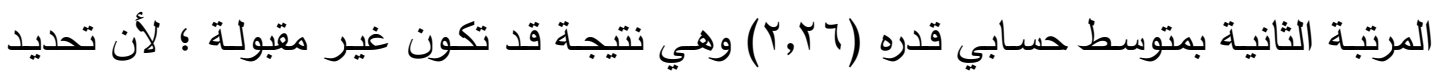

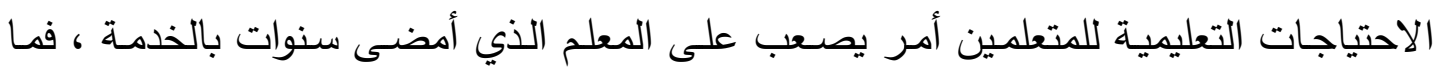
بالك بالطالب المعلم ؟ وقد يعود ذلك إلى عصر المعرفة المفتوح حيث قام كل فرد بالمشاركة بالنقاشـات المثارة في مختلف ميادين الحياة ، الأمر الذي دفع أفراد العينة إلى التتبؤ - سواء أكان ذلك التتبؤ عن وعي أم لا - بالقدرة على تحديد الاحتياجات التعليمية للمتعلمين.

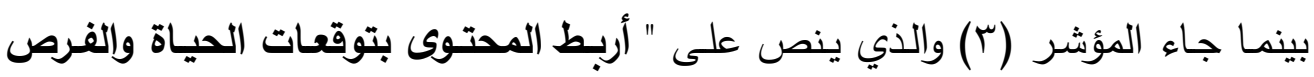
الوظيفية ذات الصلة " في المرتبة الأخيرة بمتوسط حسابي قدره (19, ( ) وهي نتيجة مقبولة ؛

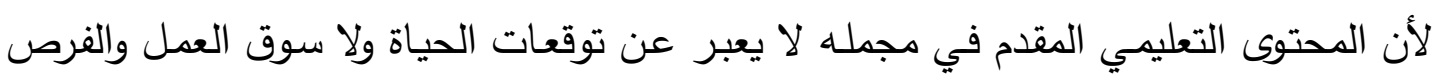

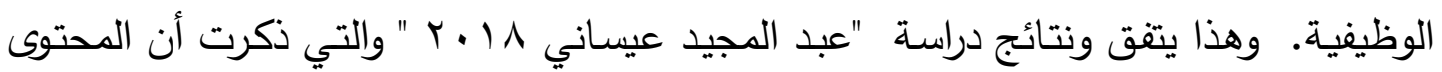
التعليمي المقدم للطلاب الجامعيين لا يحقق الأهداف المرجوة منه. 


\section{جلول (7)}

ترتيب ودرجة توفر مؤشرات معيار التقيييروالتقويه من وجهة نظر العينة

\begin{tabular}{|c|c|c|c|c|c|c|c|c|c|c|}
\hline \multirow{2}{*}{ الترتيب } & \multirow{2}{*}{ الن الوزن } & \multirow{2}{*}{ المتوسط } & \multicolumn{2}{|c|}{ غير متوفر } & \multicolumn{2}{|c|}{ إلى حدما } & \multicolumn{2}{|c|}{ متوفر } & \multirow{2}{*}{ 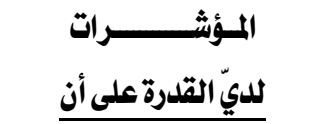 } & \\
\hline & & & $\%$ & تكرار & $\%$ & تكرار & $\%$ & تكرار & & \\
\hline r & •, v\& & $r, r T$ & ro & 1.4 & rv & lir & 纟^ & r.. & ألتزم في أهدافافالدرس بالنهج & 1 \\
\hline$\wedge$ & •, ४६ & $1,1 \xi$ & $0\}, 0$ & rm & rq,o & 11. & 19 & va & أستطيي إدارة الوقت لتفطية & \\
\hline 7 & •, 74 & 1,91 & ro & 180 & $r, r$ & ir. & $r r, v$ & 18. & أُعد أهداف تعليمية متنوعة & r \\
\hline 9 & •, $₫ \xi$ & $1,4 r$ & or & 117 & $r r, r$ & Irq & $10, \mathrm{r}$ & 70 & أحلل المحتوى التقليمي & $\xi$ \\
\hline 1 & $\cdot, \Lambda \cdot$ & $r, \& r$ & $\wedge$ & $r$ & $\{1, \xi$ & ivr & $0 ., 7$ & r. & أحدد مخرجات التعله الموجودة & 0 \\
\hline$r$ & , iv & $r, \cdot r$ & $\mathrm{rr}, \mathrm{O}$ & 1ro & $r, r$ & ir. & $r q, r$ & 10. & أختار الوسائل التعليمية & 9 \\
\hline 0 & $\cdot, 74$ & r & $r o, r$ & 1.0 & ₹१ & r.r & $r o, A$ & 1.4 & أحدد استراتيجيات التلدريس & $\mathrm{v}$ \\
\hline$\xi$ & $\cdot, \mathrm{Tr}$ & $r, \cdot 1$ & rq & $1+1$ & $\$ 1,0$ & 194 & $\mathrm{rY}, \mathrm{O}$ & $11 \xi$ & احلد الأنشطة التعليمية & $\wedge$ \\
\hline v & • १६ & $1,9 r$ & ro & $1 \$ 4$ & rq & $1 \leqslant 9$ & rq & ir. & أحدد أساليب التقويم المناسبة & 9 \\
\hline
\end{tabular}

جلدول (v)

مستويات معيار التقييـوالتقويه

\begin{tabular}{|c|c|c|}
\hline النسبة. & التكرار & المستوى \\
\hline$r Y, A$ & 174 & منخفض \\
\hline$r o, r$ & $\mid \& A$ & متوسط \\
\hline$r 1,0$ & |r| & مرتفع \\
\hline 1... & $\$ 10$ & المجموع \\
\hline
\end{tabular}

يتضح من جدول (V) السابق أنه قد تم تقسيم معيار التقييم والتقويم إلى ثلاثة مستويات

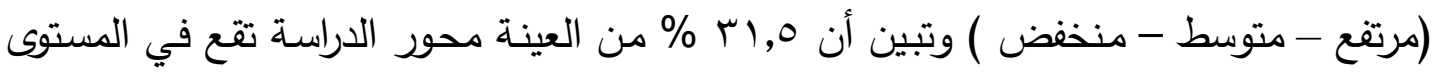

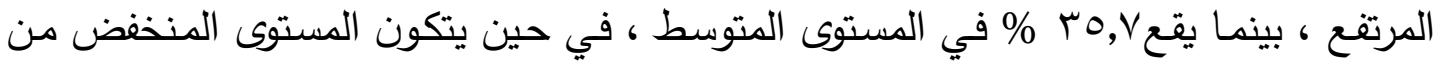




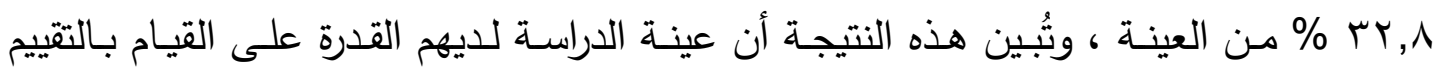
والتقويم لتلاميذهم بصورة متوسطة ؛ وربما يرجع ذلك إلى أسباب عدة منها ضعف الاهتمام

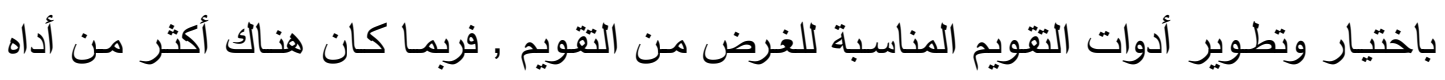

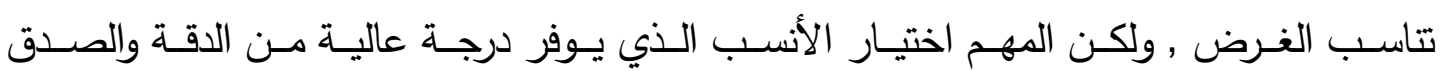

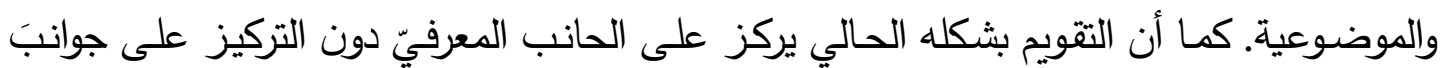
أخرى مهمّة في تكوين شخصية المتعلم، سواءً كاتت مهاراتية أو ترتبط بالمحيط الخارجي.

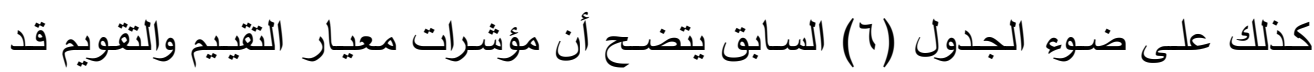
تحقتت بدرجات متفاوتة من وجهة نظر أفراد العينة ؛ فقد جاء المؤشر (0) والذي ينص على " أحلد مخرجات التعلم الموجودة في الدرس " في المرتبة الأولى بمتوسط حسابي قدره (r ع, ب) وهي نتيجة مقبولة ؛ لأن الطالب المعلم أثناء التربية العملي يتم التركيز معه أكثر على كيفية الإعداد وتحديد مخرجات التعلم الأمر الذي يجعله على دراية به.

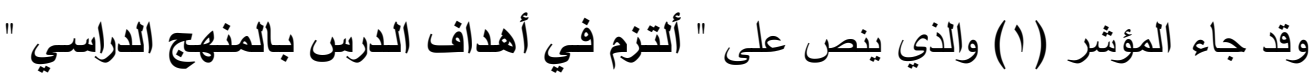

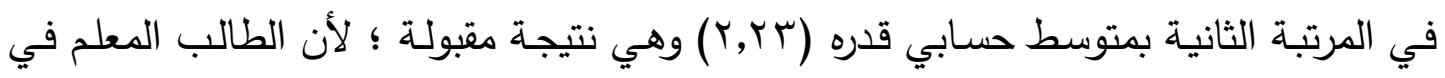

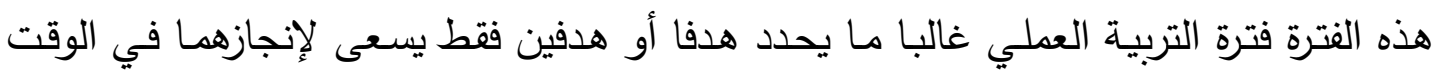
الدحدد له أثناء التدريب في حجرة الدرس ، ويكون ملتزما بتلك الأهداف التي ظل طيلة الوقت يجهز لها لدرجة أن بعض أفراد العينة ذكر أنه لا ينام الليلة التي تسبق ذهابه للتربية العملي.

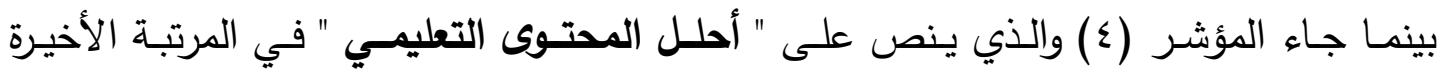
بمتوسط حسابي قدره (rآ, (1) وقد يرجع ذلك لصعوبة تحليل المحتوى التعليمي ، وقد يعود لبعض القصور في الههارات العليا والكفاءة لاى الطالب المعلم ؛ حيث إن الاهتمام في سنوات الدراسة بالكلية كان منصبا بدرجة كبيرة حول المعارف والمهارات الأكاديمية والتي تؤهل الطلاب

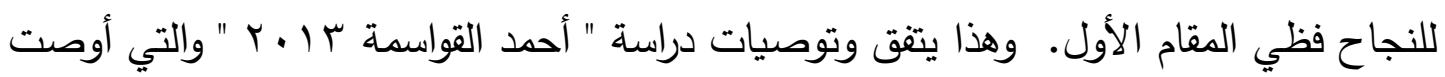
بتثجيع أعضاء هيئة التدريس على ممارسة جميع أنواع وأنماط التنكير . وبناء برامج خاصـة

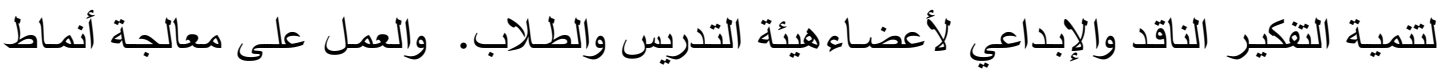
التنكير التقليدية عند أعضاء هيئة التدريس والطلبة. 


\section{جلدول (^)}

ترتيب ودرجة توفر مؤشرات معيار توظيف طرائق التدريس لتحقيق أهداف التعله من وجهة نظر العينة

\begin{tabular}{|c|c|c|c|c|c|c|c|c|c|c|}
\hline \multirow{2}{*}{ الترتيب } & \multirow{2}{*}{ النسبي } & \multirow{2}{*}{ المتوسط } & \multicolumn{2}{|c|}{ غير متوفر } & \multicolumn{2}{|c|}{ إلى حلد ما } & \multicolumn{2}{|c|}{ متوفر } & \multirow{2}{*}{ 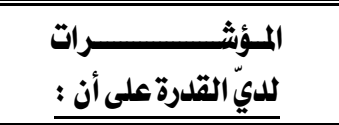 } & \multirow{2}{*}{ Aر } \\
\hline & & & $\%$ & التكرار & $\%$ & التكرار & $\%$ & التكرار & & \\
\hline$r$ & $\cdot, r V$ & r,rr & 10 & Ir & $r q, 7$ & 10r & $\{\Lambda, \xi$ & $r+1$ & 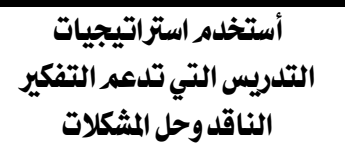 & 1 \\
\hline$r$ & $\cdot, \mathrm{VA}$ & $r, r q$ & $\| 1, \wedge$ & $\leqslant 9$ & $\xi$. & 177 & $\{\Lambda, r$ & r.. & تلاءه الأهدافيجيات التدريسية & $r$ \\
\hline 1 & $\cdot, \wedge \cdot$ & $r, \xi \theta$ & $1 r, 7$ & or & $r \xi, \vee$ & I\&\& & or,, & riq & عند تنفيذ الملهار بالتعليموية & $r$ \\
\hline 0 & $\cdot, 70$ & $r, \bullet$ & 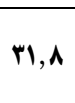 & Irr & ro & 180 & $r \mu, r$ & IrA & فأوظف استراتيجيات تعليمية & $\varepsilon$ \\
\hline$\varepsilon$ & $\cdot, 71$ & $r, \cdot \xi$ & $r r, \Lambda$ & 99 & $\{\wedge, r$ & r.. & $r \Lambda$ & 117 & أراعي الفروق الفردية بين & 0 \\
\hline$\xi$ & $\cdot, 71$ & $r, \cdot \xi$ & $r r, \Lambda$ & 99 & $\{\Lambda, r$ & r.. & $r A$ & 117 & 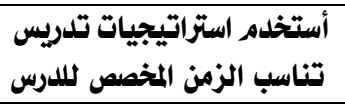 & 7 \\
\hline
\end{tabular}

جلدول (9)

مستويات معيار توظيف طرائق التدريس لتحقيق أهداف التعله

\begin{tabular}{|c|c|c|}
\hline النسبة\%٪ & التكرار & المستوى \\
\hline 19,1 & $\Delta r$ & منخفض \\
\hline$\xi \cdot, 0$ & 171 & متوسط \\
\hline$r q, \vee$ & 170 & مرتفع \\
\hline 1... & $\$ 10$ & الججموع \\
\hline
\end{tabular}

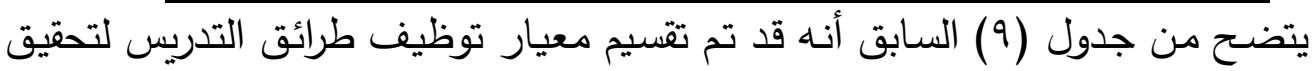

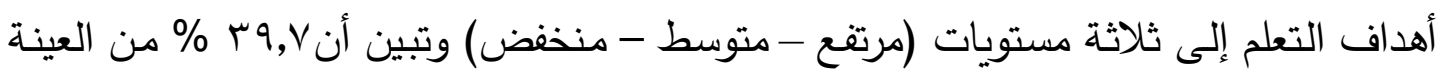

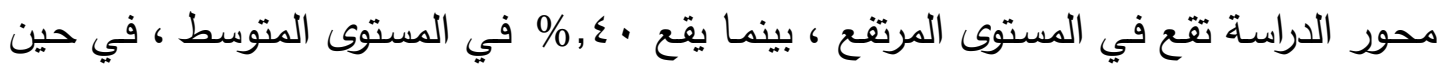

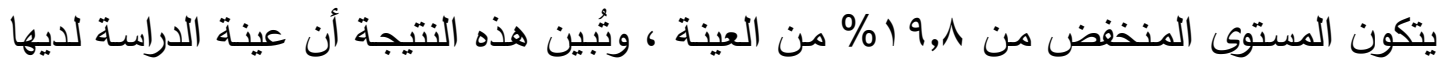

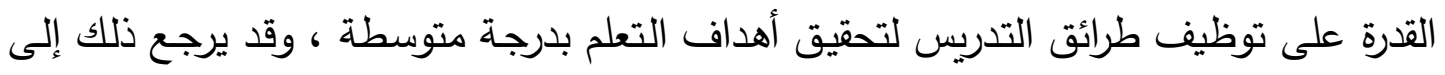

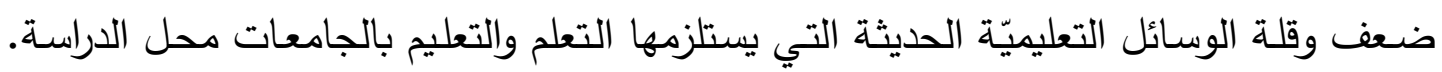

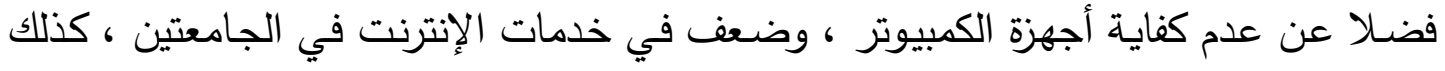

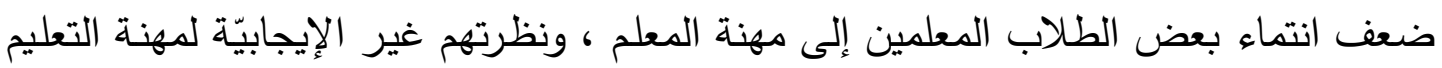

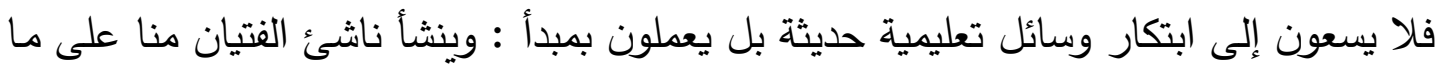

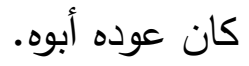




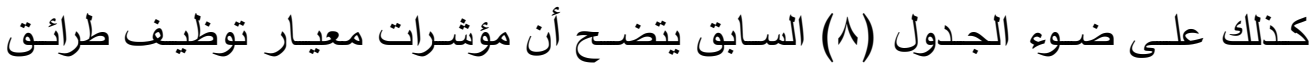
التدريس لتحقيق أهداف التعلم قد تحققت بدرجات متففوتة من وجهة نظر أفراد العينة ؛ فقد جاء

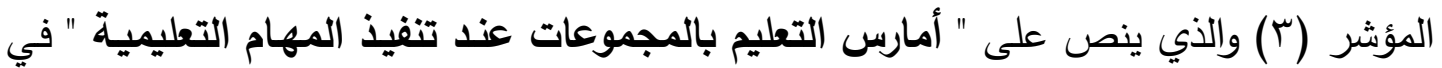

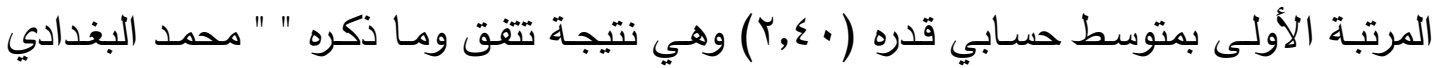

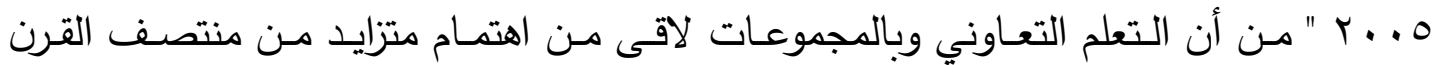

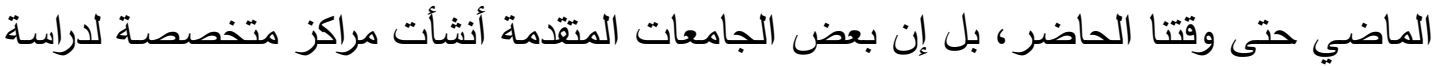

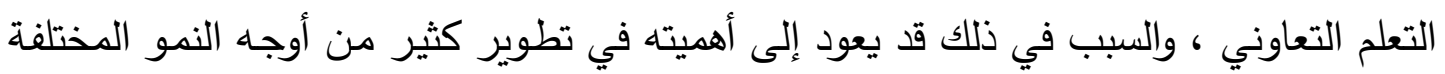

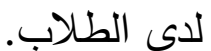

وقد جاء المؤشر (r) والذي ينص على " أقدم استراتيجيات تدريس تـلاءم الأهداف

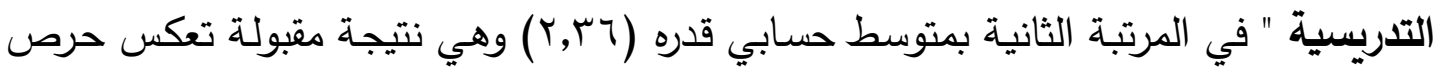

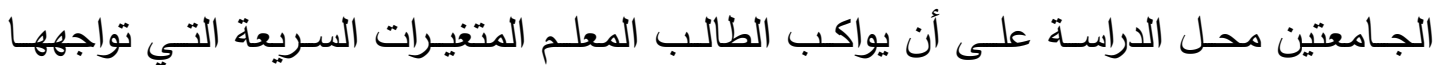
المجتمعات على الأصعدة كافة.

بينما جاء المؤشر (ع) والذي ينص على " أوظف استراتيجيات تعليمية فعالة ومناسبة

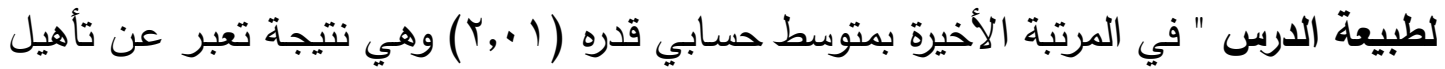

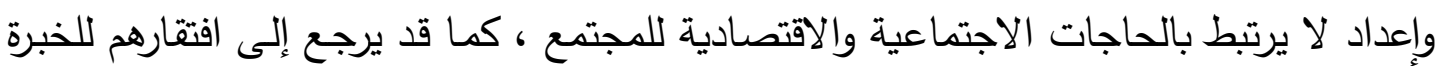

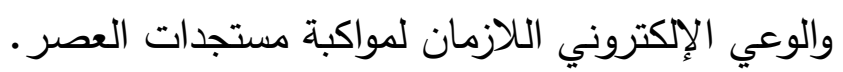

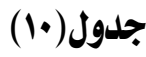

ترتيب ودرجة توفر مؤشرات معيار مهارات الاتصال اللفظي وغير اللفظي منوجهة نظر العينة

\begin{tabular}{|c|c|c|c|c|c|c|c|c|c|c|}
\hline \multirow{2}{*}{ الترتيب } & \multirow{2}{*}{ الن الوزي } & \multirow{2}{*}{ المتوسط } & \multicolumn{2}{|c|}{ غير متوفر } & \multicolumn{2}{|c|}{ إلى حدما } & \multicolumn{2}{|c|}{ متوفر } & \multirow{2}{*}{ 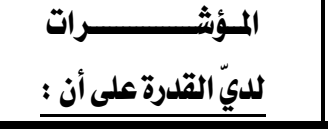 } & \\
\hline & & & $\%$ & التكرار & $\%$ & التكرار & $\%$ & التكرار & & |" \\
\hline 1 & •,Ar & $r, r q$ & $1 v, 7$ & vr & ro, 1 & $1 \leqslant 1$ & $\varepsilon \eta, \gamma$ & $19 \xi$ & ألمناسيالدقيق التواصل الكلابابي. & 1 \\
\hline$\xi$ & 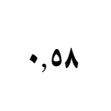 & l, v₹ & $\{7,0$ & 194 & $r r, O$ & 170 & rI & $\Delta V$ & أطبق برامج علاجية للطلاب & $r$ \\
\hline$r$ & •, 49 & $1, \mathrm{VY}$ & $\varepsilon r, r$ & 197 & rA & 119 & $\boldsymbol{Y} \xi, \Lambda$ & $1 . r$ & أنحدثباللفة العربية/الفصحى & $r$ \\
\hline r & •, $\mathrm{v \varepsilon}$ & $r, r r$ & ro,r & 1.0 & $r q, 0$ & 11. & $\{\Lambda, r$ & $r \cdots$ & ألتزنمبحسن الإلقاءوتتنويعه بما & $\xi$ \\
\hline 0 & $\cdot, 07$ & 1,80 & or, r & m & $\boldsymbol{r}, \boldsymbol{r}$ & 1.1 & $r, \xi$ & ar & 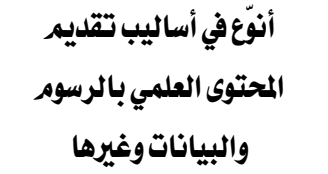 & 0 \\
\hline
\end{tabular}




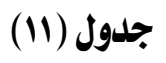

مستويات معيار مهارات الاتصال اللفظي وغير اللفظي

\begin{tabular}{|c|c|c|}
\hline النسبة\%٪ & التكرار & المستوى \\
\hline$r \Lambda$ & 101 & منخفض \\
\hline$\uparrow q, \xi$ & Irr & متوسط \\
\hline$r, T$ & 170 & مرتفع \\
\hline $1 \cdots$ & $\$ 10$ & المجموع \\
\hline
\end{tabular}

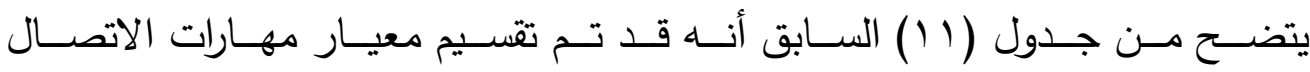

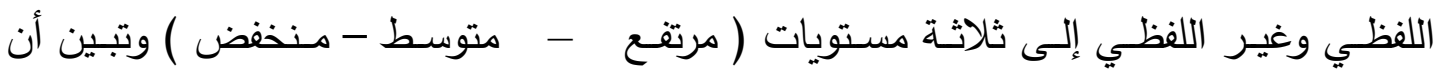

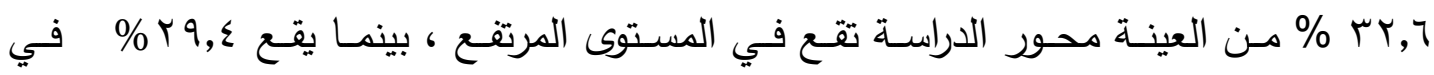

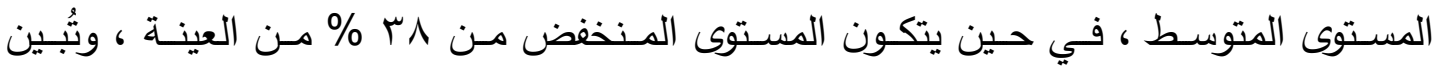

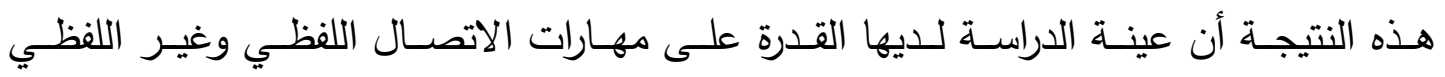

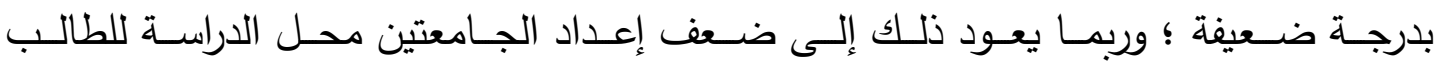

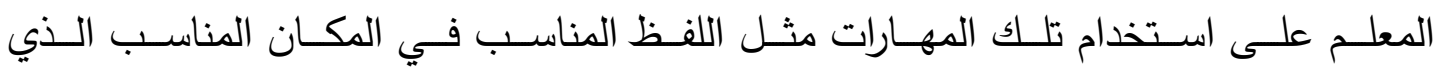

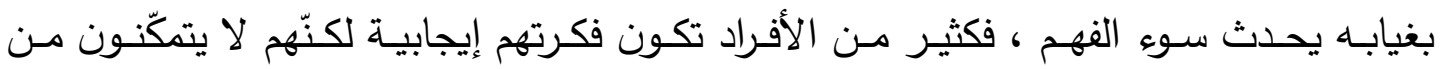
التعبير عنها لفظياً بشكل سليم ، ممّا يؤدّي إلى إعاقة فهم الآخرين لها. وربما تعود النتيجة السابقة إلى عدم مراعاة الجامعتين محل الدراسة لمهاراة اختلاف نبرة

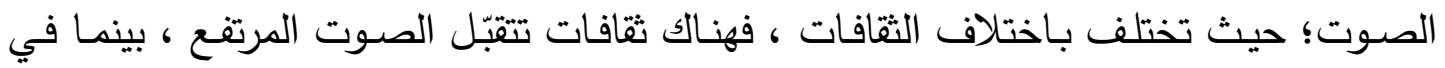

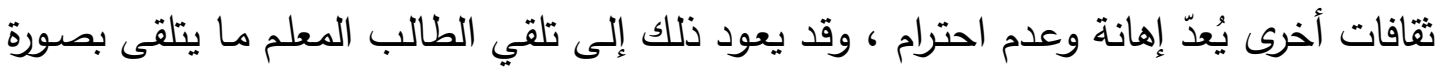

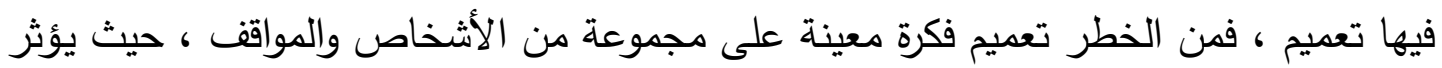

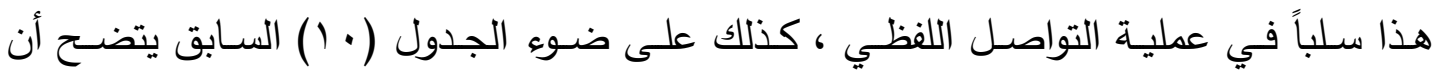

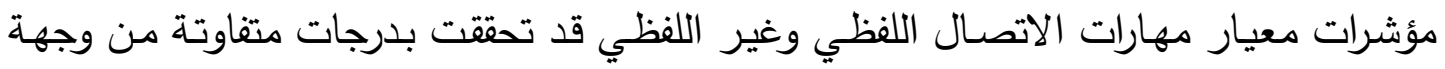

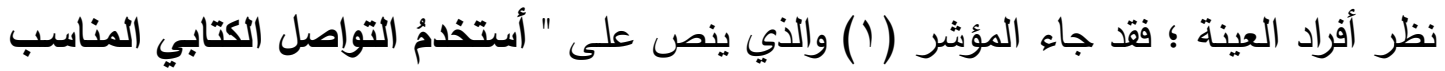

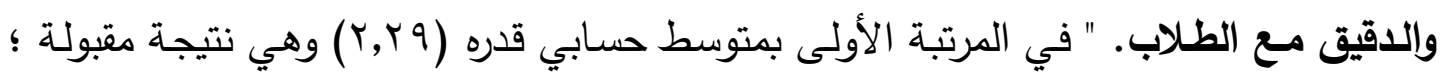

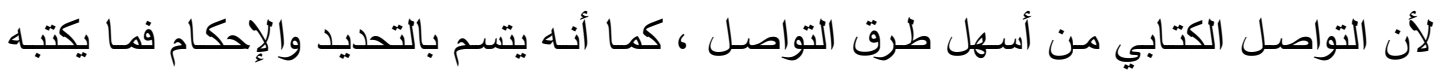

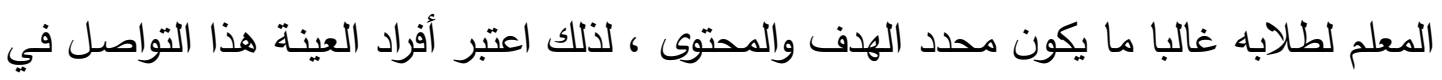
مقدمة استجابتهم. 
وقد جاء المؤشر (ع) والذي ينص على " ألتزم بحسن الإلقاء وتنويعه بما يتناسب مـع

الموقف التعليمي " في المرتبة الثانية بمتوسط حسابي قدره (Y,Y,Y) وهي نتيجة لا تطابق الواقع ؛ لأن الربط بين المتغيرات " حسن الإلقاء - التتويع فيه - مناسبة الموقف التعليمي " كلها أمور صعبة تحتاج إلى الممارسة الطويلة والخبرة ، والتدريب والمران ، وورش العمل في الدورات التدريبية. وقد جاء المؤشر (0) والذي ينص على " أنوّع في أسـاليب تقديم المحتوى العلمي بالرسوم والصور والبيانات وغيرها " في المرتبة الأخيرة بمتوسط حسابي قدر (0ء, ا ) وقد يرجع ذلك إلى عدم ارتباط المقررات الدراسية بركائز التنمية والتنمية المستدامة من حيث المهارات الأساسية التي يحتاجونها في هذا القرن والسلوكيات التي ينبغي عليهح ممارستها.

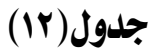

ترتيب ودرجة توفر مؤشرات معيار إثارة الانتباه والدافية من وجهة نظر العينة

\begin{tabular}{|c|c|c|c|c|c|c|c|c|c|c|}
\hline \multirow{2}{*}{ الترتيب } & \multirow{2}{*}{ النسبي } & \multirow{2}{*}{ المتوسط } & \multicolumn{2}{|c|}{ غير متوفر } & \multicolumn{2}{|c|}{ إلى حلد ما } & \multicolumn{2}{|c|}{ متوفر } & \multirow{2}{*}{ 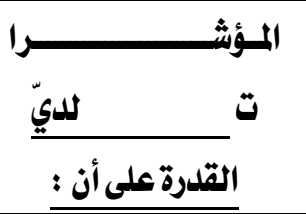 } & \multirow[b]{2}{*}{ م } \\
\hline & & & $\%$ & التكرار & $\%$ & التكرار & $\%$ & التكرار & & \\
\hline$\xi$ & •, 71 & $r, \bullet$ & $r \cdot, \Lambda$ & $\mid r A$ & rr,o & 1ro & rq, & 10r & أتفاعل مع الطلبة أثناء & 1 \\
\hline 0 & •, 79 & $r$ & $r 1,7$ & |r| & rq & 10. & $r, r$ & IT\& & لأنوع في التعزيزات & $r$ \\
\hline$r$ & •, VY & r,17 & $r V, r$ & $11 \%$ & $r q, \xi$ & Irr & $\varepsilon r, r$ & 14. & أوزع بصري جيلا على الطلبة & $r$ \\
\hline 0 & $\cdot, 77$ & $r$ & $r r, r$ & 180 & $r r, r$ & Irs & rq & $|\xi|$ & بصورة سريعة وايجابية لأسئلة الطلبة & $\xi$ \\
\hline$r$ & •, $\mathrm{\vee A}$ & r, ro & r. & $\Delta r$ & $r \&, Y$ & $1 . r$ & $\Delta 0, \xi$ & r. & أستخدم عبارات التعزيز & 0 \\
\hline 1 & •, 19 & $r, 01$ & $1 \xi, 0$ & 7. & $\mathbb{I r}, \mathrm{V}$ & or & YY,Y & $r \cdot r$ & أستخده عبارات خالية & 7 \\
\hline 7 & $\cdot, 77$ & 1,99 & $r v, T$ & 107 & ro,r & 1.0 & $r v$ & $10 \xi$ & الطارك أكبر علد من في أثناء تعلمهي & $v$ \\
\hline
\end{tabular}




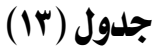

مستويات معيار إثارة الانتباهوالدافمية

\begin{tabular}{|c|c|c|}
\hline النسبة ٪ & التكرار & المستوى \\
\hline$r \wedge$ & 117 & منخفض \\
\hline$r V, O$ & $11 \varepsilon$ & متوسط \\
\hline$\{\xi, 0$ & 110 & مرتفع \\
\hline $1 .$. & $\$ 10$ & المجموع \\
\hline
\end{tabular}

يتضح من جدول (r ( ) السابق أنه قد تم تقسيم معيار إثارة الانتباه والدافعية إلى ثلاثة

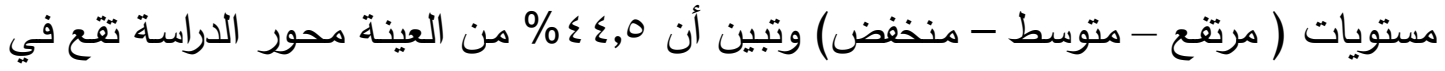

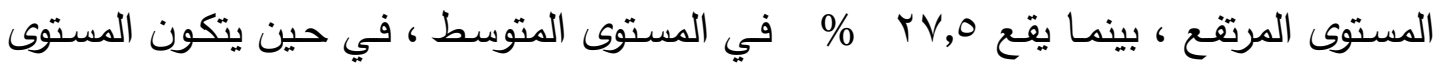

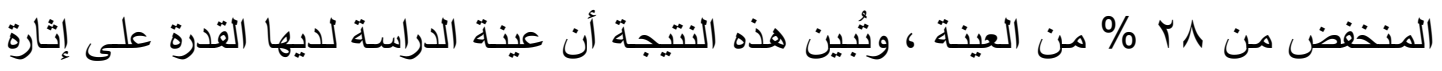

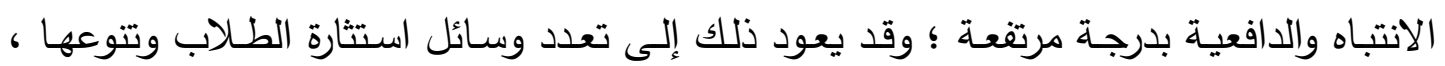

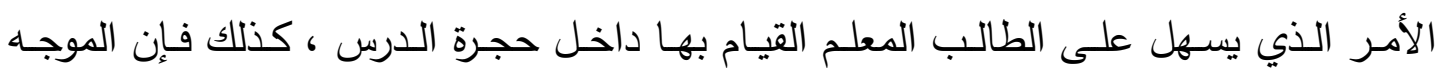

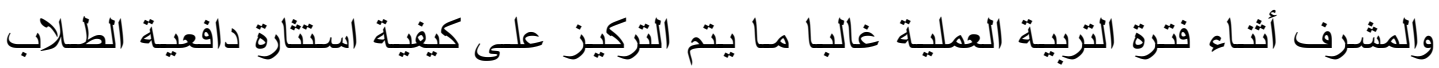
وجذب انتباههم.

كذلك على ضوء الجدول (r) ( I السابق يتضح أن مؤشرات معيار إثارة الانتباه والدافعية

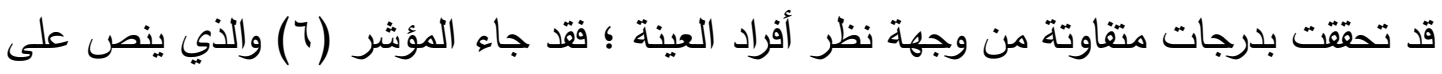

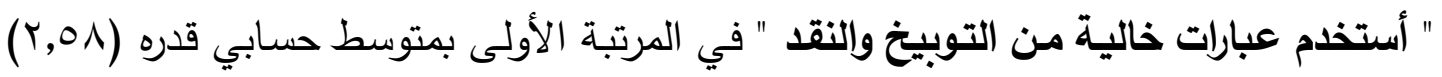

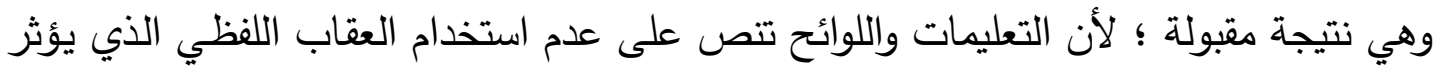

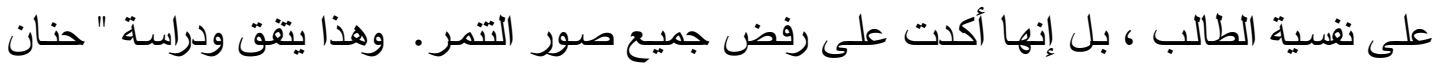

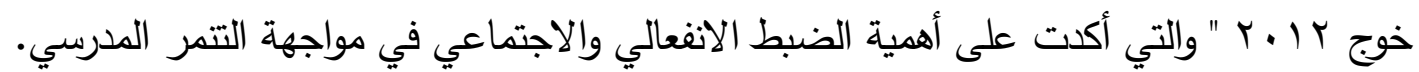

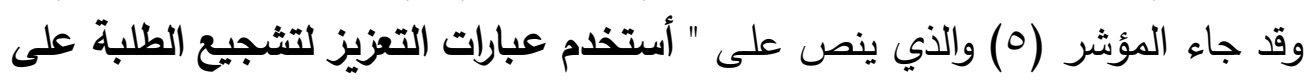

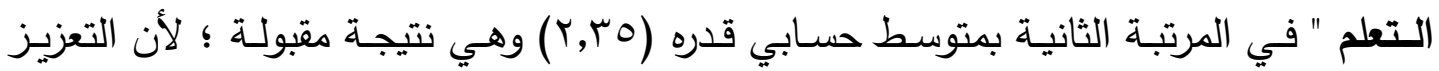

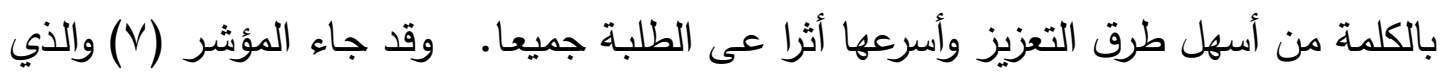

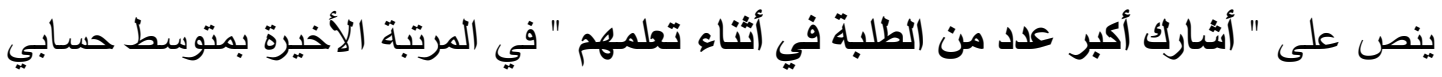

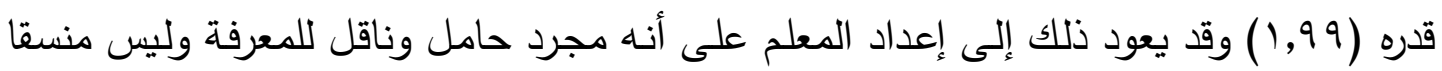

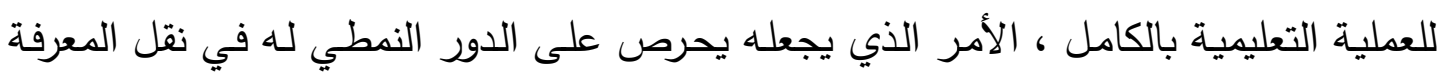
دون الحرص على مشاركة أكبر عدد من طلابه أثناء عملية التعلم. 
جدول(1)

ترتيب ودرجة توفر مؤشرات معيار تنمية شخصية الطالب من وجهة نظر العينة

\begin{tabular}{|c|c|c|c|c|c|c|c|c|c|c|}
\hline \multirow{2}{*}{ الترتيب } & \multirow{2}{*}{ الن الوزن } & \multirow{2}{*}{ المتوسط } & \multicolumn{2}{|c|}{ غير متوفر } & \multicolumn{2}{|c|}{ إلى حد ما } & \multicolumn{2}{|c|}{ متوفر } & \multirow{2}{*}{ 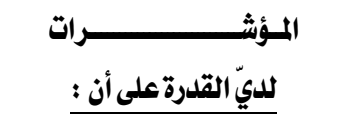 } & \\
\hline & & & $\%$ & التكرار & $\%$ & التكرار & $\%$ & 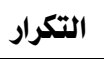 & & \\
\hline$r$ & $\cdot, 71$ & 1,10 & rA, r & 109 & $r v, T$ & 107 & Yq & 10 & أكشف عن المواهب والقدرات & 1 \\
\hline 9 & • & I,AY & $r v, r$ & 100 & rı & $10 \Lambda$ & $r \&, 7$ & $1 . r$ & أوفر فرصا لتنمية الههارات للى & $r$ \\
\hline$\wedge$ & $\cdot, 7$ & $1, \wedge \xi$ & ץq & $|\xi|$ & $\xi Y, Y$ & 191 & $M A, r$ & VI & ألبي حاجات الطلبة النفسية & $r$ \\
\hline$\xi$ & $\cdot, 77$ & $r$ & rq & Ir. & \&Y & ivo & rq & Ir. & أنقذ طرق فعالة في زيادة & $\xi$ \\
\hline$r$ & $\cdot, 79$ & $r, \bullet V$ & $r O, \Lambda$ & $1 \cdot v$ & $\xi \cdot, 0$ & 171 & $r \mu, \gamma$ & $1 \varepsilon$ & أتابع أحوال الطلبة الصحية & 0 \\
\hline r & $\cdot, \mathrm{V} \varepsilon$ & $r, r r$ & $19, Y$ & Ar & $r v, T$ & 107 & $\{r, q$ & iry & أنفذ سلوكيات إيجابية هادفة & 9 \\
\hline 1 & •, vo & r, ro & $1 \xi, 0$ & 7. & §o,r & $1 \wedge \Lambda$ & $\varepsilon \cdot, r$ & 178 & أتعرف الخصائص التي تميز & $v$ \\
\hline 0 & $\cdot, 70$ & 1,90 & rq, ₹ & 101 & $r I, \Lambda$ & IFr & $\mu, \Lambda$ & ITr & أعزز الانضباط الذاتي للدى & 1 \\
\hline 9 & •, Or & $1, \mathrm{VH}$ & $\{\Lambda\rceil$, & r.r & $r q, \xi$ & Irr & rr & 91 & أعمالهم الذاتية أطلبة أعمال تقويه & 9 \\
\hline
\end{tabular}

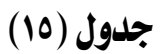

مستويات معيار تنمية شخصية الطالب

\begin{tabular}{|c|c|c|}
\hline النسبة\%٪ & التكرار & المستوى \\
\hline$r, Y$ & $|r|$ & منخفض \\
\hline$r \Lambda, \Lambda$ & 171 & متوسط \\
\hline$r q, 7$ & IrT & مرتفع \\
\hline $1 .$. & $\$ 10$ & المجموع \\
\hline
\end{tabular}


يتضـح مـن جدول (10 ) السـابق أنسه قد تم تقسيم معيـار تتميـة شخصية الطالب

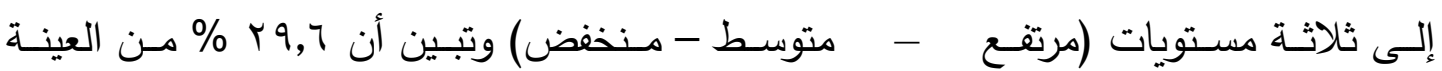

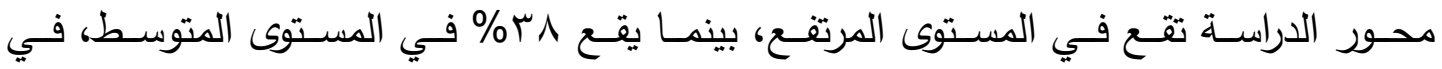

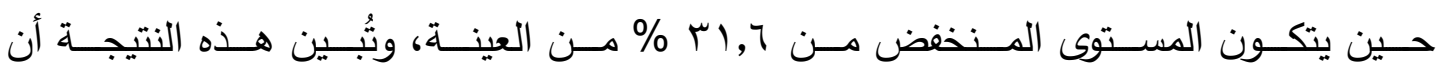
الجـامعتين عينـة الدراسـة لـديها القدرة على تتميـة شخصـية الطالب بدرجـة متوسطة، وقدـ

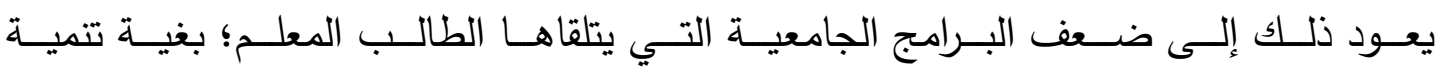
شخصيته أثناء فترة الدراسة والإعداد التربوي.

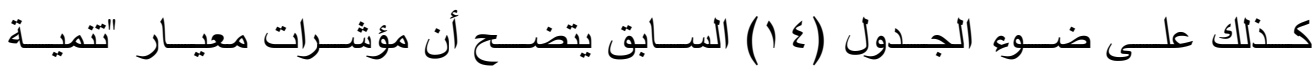

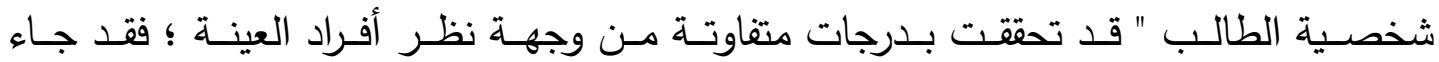

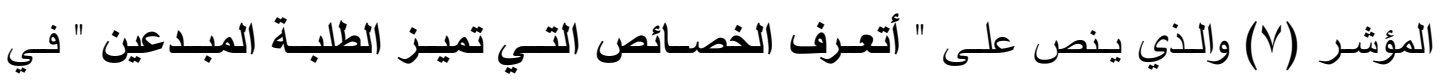

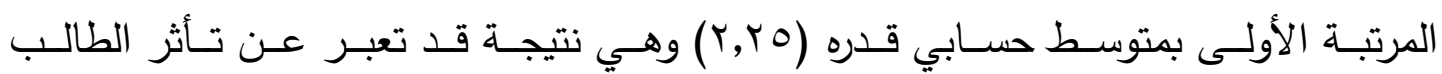

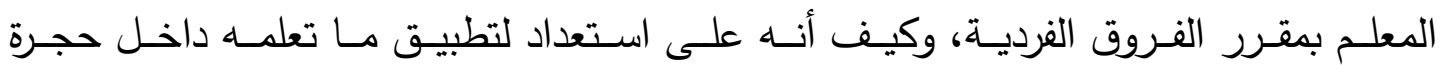
الدراسة مستقبلا.

وقد جاء المؤشر (T) والذي ينص على " أنفذ سلوكيات إيجابية هادفة " في المرتبة الثانية بمتوسط حسابي قدره (Y,Y,Y) وهي نتيجة مقبولة تعبر عن إحساس الطالب المعلم بأنه قدوة، وأنه على استعداد لتنفيذ السلوكيات الإيجابية المفيدة.

بينما جاء المؤشر (9) والذي ينص على " أثجع الطلبة على تقويم أعمالهم الذاتية

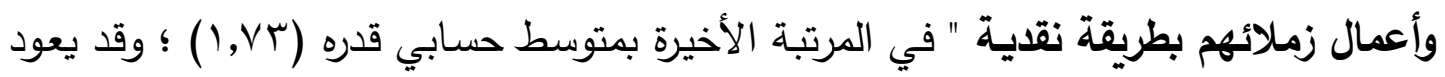

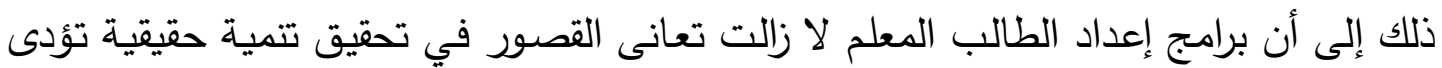

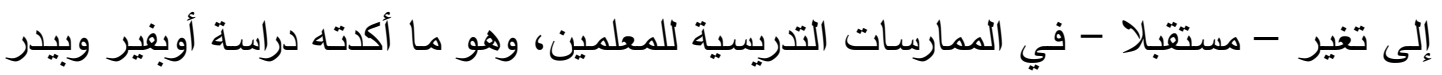
(Opfer \& Pedder, 2010)

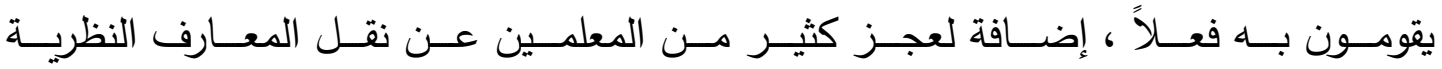
للممارسة والتطبيق. 


\section{جلول (17) - (19)}

ترتيب ودرجة توفر مؤشرات معيار إدارة الصف الدراسي من وجهة نظر العينة

\begin{tabular}{|c|c|c|c|c|c|c|c|c|c|c|}
\hline \multirow{2}{*}{ | الترتيب| } & \multirow{2}{*}{ النسب الوزن } & \multirow{2}{*}{ المتوسط } & \multicolumn{2}{|c|}{ غير متوفز } & \multicolumn{2}{|c|}{ إلى حلد ما } & \multicolumn{2}{|c|}{ متوفر } & \multirow{2}{*}{ 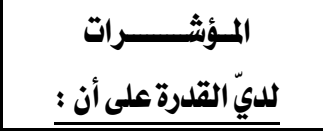 } & \multirow{2}{*}{ هـ } \\
\hline & & & $\%$ & ت ت تكرار & $\%$ & ت ت تكرار & $\%$ & التكرار & & \\
\hline 0 & $\bullet, 77$ & $r$ & $r q, 1$ & 10. & $r V, r$ & 110 & $r q, 1$ & 10. & 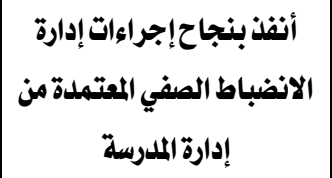 & 1 \\
\hline$r$ & $\cdot, 70$ & $1,9 V$ & $r r, O$ & Iro & $r V, \Lambda$ & lor & $r q, 7$ & Irr & أوفر بيئة صفية تدعم وتشجع & $r$ \\
\hline 7 & $\cdot, 77$ & 1,99 & $r q, \Lambda$ & IrE & $\xi \cdot, 0$ & 171 & $r q, 7$ & Irr & أعيل توجيه السلوكيات غير & $r$ \\
\hline$r$ & - Yo & $r, r q$ & $1 \varepsilon, r$ & 09 & $\boldsymbol{\varepsilon} \boldsymbol{\xi}, \boldsymbol{\Lambda}$ & 119 & $\$ 1$ & iv. & أدير الوقت والمواد التعليمية & $\varepsilon$ \\
\hline$\xi$ & $\cdot$, iv & $r, \cdot r$ & $r \xi$ & $1 .$. & $r q, \xi$ & r.O & $r q, O$ & 11. & أعززالسلوكيات المناسبة. & 0 \\
\hline$r$ & $\cdot, 79$ & $r, \bullet Y$ & $r q, r$ & 1.9 & $\xi \cdot, \bigvee$ & 179 & rr & IrV & أتعامل مع الطلبة وققا & 7 \\
\hline 1 & $\cdot, \mathrm{VI}$ & $r, r r$ & 11,7 & $\{\Lambda$ & $r q, 0$ & $17 \xi$ & $\{\Lambda, q$ & $r \cdot r$ & والستخلم أساليب النصح & $v$ \\
\hline
\end{tabular}

جلول (IV)

مستويات معيار إدارة الصف الدراسي

\begin{tabular}{|c|c|c|}
\hline النسبةٌ٪ & التكرار & المستوى \\
\hline ro & $1 \cdot \varepsilon$ & منخفض \\
\hline$\xi$ & 179 & متوسط \\
\hline ro & 180 & مرتفع \\
\hline $1 .$. & $\$ 10$ & المجموع \\
\hline
\end{tabular}

يتضح من جدول ( V ) السابق أنه قد تم تقسيم معيار إدارة الصف الاراسي إلى ثلاثة مستويات ( مرتفع - متوسط - منخفض ) وتبين أن هم \% من العينة محور الدراسة تقع في المستوى المرتفع، بينما يقع • ؟\% في المستوى المتوسط، في حين يتكون المستوى المنخفض 
مـن هب \% مـن العينـة، وتُبين هذه النتيجـة أن عينـة الدراسـة لديها القدرة على إدارة الصفـ الدراسي بدرجة متوسطة؛ وهي نتيجة تعكس ضعف اهتمام الجامعتين محل الدراسة بأن يتقن

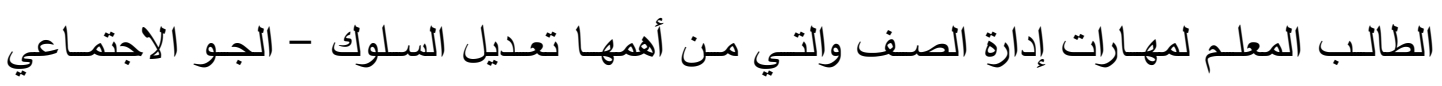
الانفعالي - عمليات الجماعـة. فضـلا عن اتقان المعلم لمادته، فعندما يفهم الطالب المعلم الأنماط السلوكية الإداريـة التي تتضمنها كل مهارة فإنه يستطيع أن يتخير الأنماط المناسبة

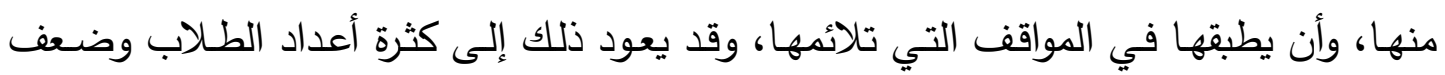

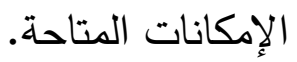

كذلك على ضـوء الجدول (T (1) السـابق يتضـح أن مؤشرات معيار إدارة الصف قد

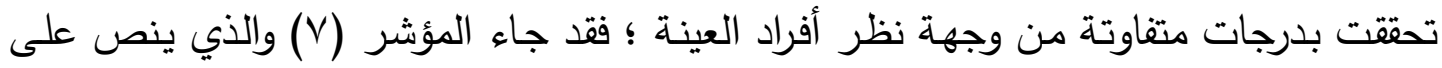

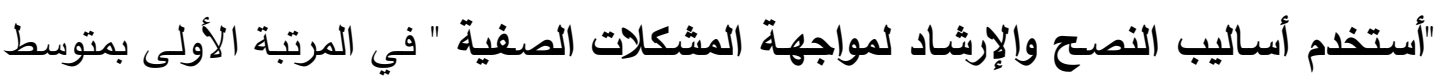

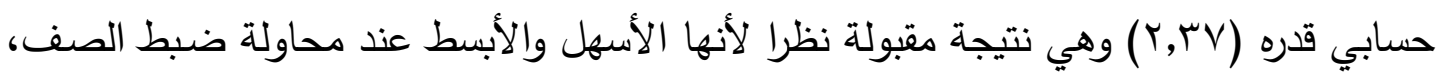

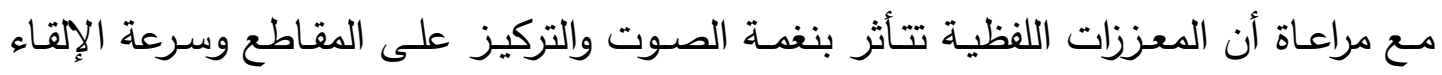

$$
\text { ودرجة ارتفاع الصوت أو انخفاضه. }
$$

وقد جاء المؤشر (ع) والذي ينص على " أديـر الوقـت والمــواد التعليميـة بفاعليـة

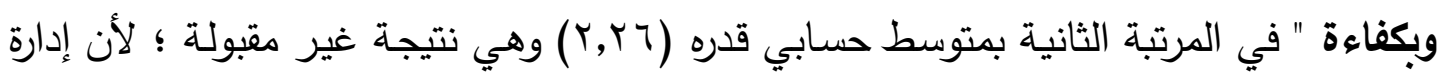
الوقت من الأمور المعقدة التي تكتسب غالبا بالخبرة والمران وطول التجربة.

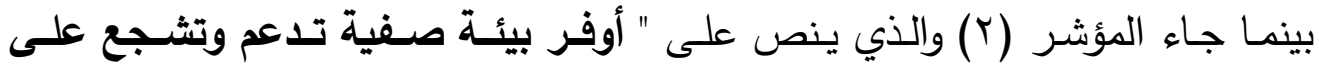

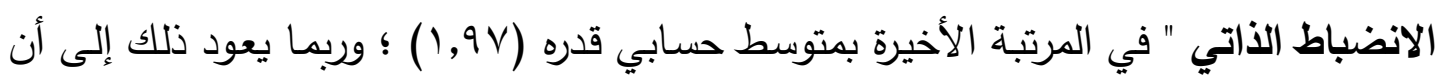

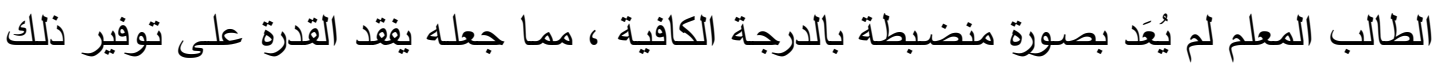

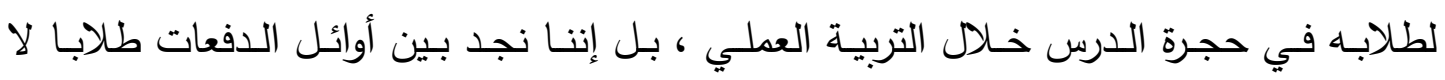

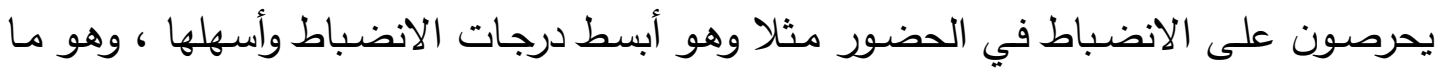

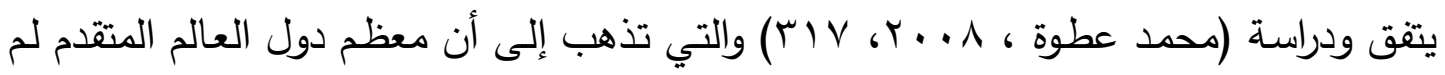

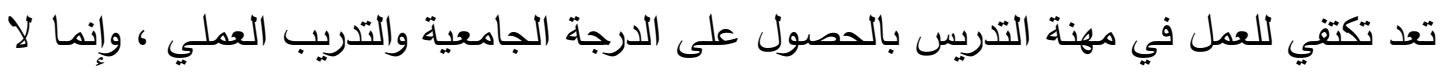

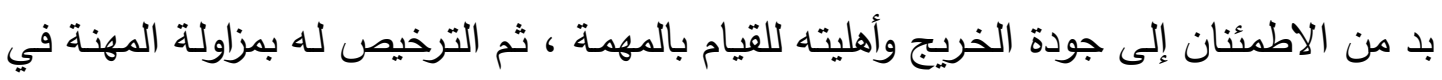

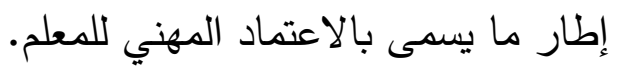




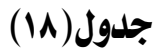

ترتيب ودرجة توفر مؤشرات معيار استخلاه الوسائل والتقنيات التعليمية من وجهة نظر العينة

\begin{tabular}{|c|c|c|c|c|c|c|c|c|c|c|}
\hline \multirow{2}{*}{ الترتيب } & \multirow{2}{*}{ النسبي } & \multirow{2}{*}{ المتوسط } & \multicolumn{2}{|c|}{ غير متوفر } & \multicolumn{2}{|c|}{ إلى حلد ما } & \multicolumn{2}{|c|}{ متوفر } & \multirow{2}{*}{ 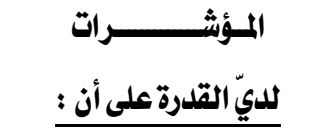 } & \\
\hline & & & $\%$ & تكرار & $\%$ & تكرار & $\%$ & تكرار & & \\
\hline 1 & $\cdot, \mathrm{VI}$ & r, rq & $r \cdot, r$ & $\wedge \xi$ & $r q, q$ & IrT & 0,1 & $r+1$ & أستخلده التقنيات المتوافرة & 1 \\
\hline$r$ & •, 71 & $1, \wedge 0$ & $\xi \varepsilon$ & IAT & $r q, \Lambda$ & 111 & $r q, 1$ & $|r|$ & أوظف معمل الحاسب في & 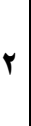 \\
\hline$\xi$ & $\cdot, 77$ & $r$ & $r r, r$ & IrA & $r r, o$ & $1 \% q$ & $r r, r$ & 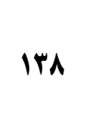 & وأستخدم الوسائل السمعية & \\
\hline 0 & $\cdot, 70$ & 1,90 & $r r, r$ & IrA & rA, r & 109 & $r \Lambda, \zeta$ & 111 & أختاس الوسيلة التعليمية & $\varepsilon$ \\
\hline$r$ & •, IV & $r, \cdot r$ & $\lceil\Lambda, \xi$ & 111 & $r q, r$ & 174 & $r r, r$ & ITE & أستخدم وسيلة جاذبة & 0 \\
\hline$r$ & $\cdot, 7 \mathrm{~V}$ & $r, \cdot 1$ & $r, r$ & & $r r, q$ & $|\xi|$ & $r \mu, \nu$ & $1 \xi 0$ & أستخلدم وسيلة مناسبة & 7 \\
\hline 7 & r & $1, \wedge 9$ & $\xi Y, \xi$ & 187 & $r O, Y$ & $1 \cdot r$ & $r I, \Lambda$ & Irr & أستفيد من خامات البيئة & \\
\hline
\end{tabular}

جلول (19)

مستويات معيار استخلاه الوسائل والتقنيات التعليمية

\begin{tabular}{|c|c|c|}
\hline النسبة & التكرار & المستوى \\
\hline$r \Psi, \xi$ & $1+9$ & منخفض \\
\hline$r r, Y$ & 100 & متوسط \\
\hline$\eta \xi$ & $|z|$ & مرتفع \\
\hline 1... & $\$ 10$ & المجموع \\
\hline
\end{tabular}

يتضـح من جدول (9 (1) السـابق أنـه قد تم تقسيم معيار استخدام الوسائل والتقنيات التعليمية إلى ثلاثة مستويات ( مرتفع - متوسط - منخفض ) وتبين أن ع ٪ \% من العينة 
محور الدراسة تقع في المستوى المرتفع ، بينما يقع ؟,Yr \% في المستوى المتوسط ، في حين يتكون المستوى المنخفض من ع,بr \% من العينة ، وتُبين هذه النتيجة أن عينة الدراسة لديها القدرة على استخدام الوسائل والتقنيات التعليمية بدرجة مرتفعة ، وهو ما يؤكد ترتيب عبارات

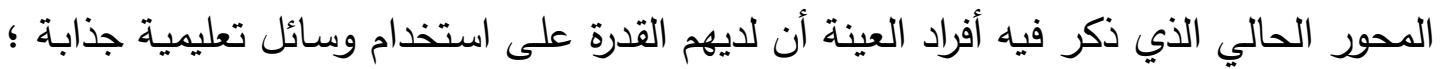
وقد يرجع ذلك إلى حالة التميز التقني لأفراد العينة في استخدام المخترعات الحديثة كالتابلت والهواتف الذكية وغيرها. وهذا يختلف ودراسة " صاموئل Samuel E.O.A 2009 "Sa والتي لوني أظهرت نتائجها أن الغالبية العظمى من المعلمين يفتقرون للكفاءات الأساسية في مجالات التكنولوجيا، وأكدت على حاجتهم للتنمية المهنية الواسعة في VI مهارة من مهارات تكنولوجيا

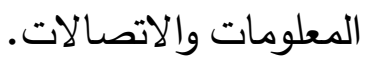

كذلك على ضـوء الجدول (1) (1) السابق يتضـح أن مؤشرات معيار استخدام الوسائل والتقنيات التعليمية قد تحققت بدرجات متفاوتة من وجهة نظر أفراد العينة ؛ فقد جاء المؤشر

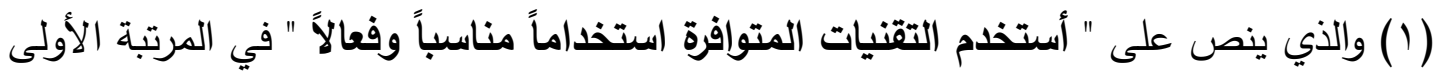

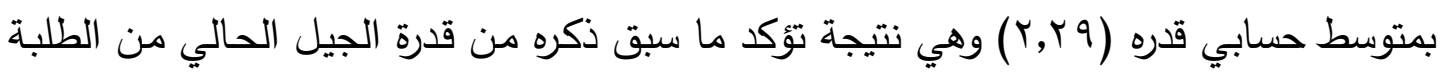
المعلمين على استخدام أدوات التكنولوجيا المختلفة.

وقد جاء المؤشر(0) والذي ينص على " أستخدم وسيلة جاذبة لانتباه الطلبة " في المرتبة الثانية بمتوسط حسابي قدره (r • r) وهي نتيجة مقبولة تعضد النتيجة السابقة وتبرهن على استعداد الطالب المعلم لاستخدام مـا يجذب طلابه في ظل عصر التقدم التكنولوجي

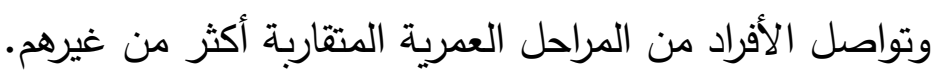

بينما جاء المؤشر (Y) والذي ينص على " أوظف معمل الحاسب في تعليم الطلبة " في المرتبة الأخيرة بمتوسط حسابي قدره (10, ( ) وهي نتيجة مقبولة تعبر عن ضعف الإمكانات المادية في مجال معامل الحاسب الآلي في الجامعات المصرية عامة والجامعتين محل الدراسة خاصة ، وكذلك الأمر بالنسبة للمدارس الدصرية. 
جلول(r)

ترتيب ودرجة توفر مؤشرات معيار التخطيط للدرس من وجهة نظر العينة

\begin{tabular}{|c|c|c|c|c|c|c|c|c|c|c|}
\hline \multirow{2}{*}{ الترتيب } & \multirow{2}{*}{ 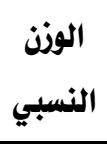 } & \multirow{2}{*}{ المتوسط } & \multicolumn{2}{|c|}{ غير متوفر } & \multicolumn{2}{|c|}{ إلى حدما } & \multicolumn{2}{|c|}{ متوفر } & \multirow{2}{*}{ 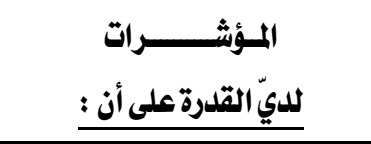 } & \multirow{2}{*}{ f } \\
\hline & & & $\%$ & ت تكرار & $\%$ & ت تكرار & $\%$ & ت تكرار & & \\
\hline 1 & $\cdot, 70$ & $1,9 V$ & ro,o & $1 \& 9$ & $r \cdot, \Lambda$ & ITA & $r r, r$ & 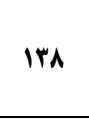 & أصمم تقييماتطاتلابية لاتتعارض & 1 \\
\hline$\varepsilon$ & .71 & $r, \bullet$ & $r V, Y$ & 110 & $r \wedge, \wedge$ & 171 & $r r, o$ & ira & أستخدم أدوات التقييم التكويني & $r$ \\
\hline$r$ & $\cdot, 71$ & $r, \bullet$ & rr,O & iro & $r \wedge, q$ & ir. & ra, & 17. & أقدم تفذية راجعة بنّاءةومتكررة & $r$ \\
\hline 1 & •, vo & r, ro & IV, & vr & rq & $17 r$ & $\varepsilon r, q$ & 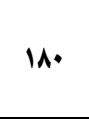 & أتواصل مع أولياء الأمور حول & $\xi$ \\
\hline$r$ & $\cdot, 7$ & $1, \wedge 1$ & $\{0,1$ & 19. & $r V, r$ & $11 \%$ & $r V$ & IIr & أقدم فرصاً لإعادة التعلم وإعادة & 0 \\
\hline r & $\cdot, 79$ & $r, \bullet r$ & ro,o & 1.9 & $\S$ & iv. & $r r, o$ & ira & أقدم استراتيجيات التقييه & 9 \\
\hline 0 & $\cdot$, iv & $r,+1$ & $r r$ & lir & $\llbracket$ & MT & rq & ir. & 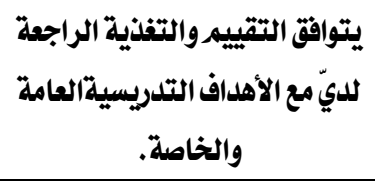 & $r$ \\
\hline$\wedge$ & $\cdot, 0 \xi$ & $1,9 \pi$ & or,o & rMA & $M, \Lambda$ & Irr & $10, r$ & 90 & أعد بنك محوسب للأسئلة & $\wedge$ \\
\hline
\end{tabular}

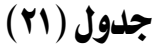

مستويات معيار التخطيط للدرس

\begin{tabular}{|c|c|c|}
\hline النسبة ٪ & التكرار & المستوى \\
\hline rr & IrV & منخفض \\
\hline$r o, r$ & $1 \leqslant 7$ & متوسط \\
\hline$r I, \Lambda$ & Irr & مرتفع \\
\hline $1 .$. & $\$ 10$ & المجموع \\
\hline
\end{tabular}

يتضـح مـن جدول (Y) السـابق أنـه قد تم تقسيم معيار التخطيط للدرس إلى ثلاثـة مستويات ( مرتفع - متوسط - منخفض ) وتبين أن ^, اب \% من العينة محور الدراسة تقع في

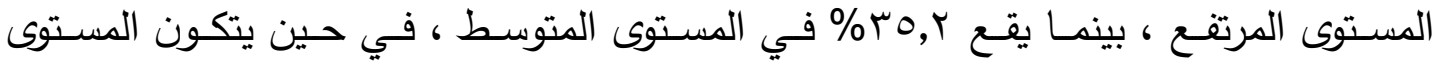




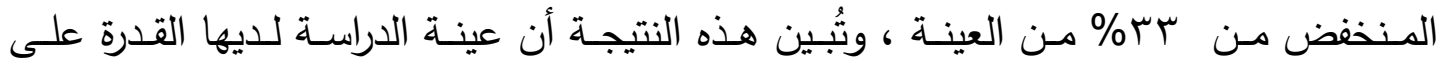
التخطيط للدرس بدرجة متوسطة ؛ وقد يرجع ذلك إلى تركيز هيئة التدريس عادة على ما هو بين أيديهم في قاعة الدرس ، وعلى استخدام بعض إستراتيجيات التدريس الجديدة مثل " التعلم

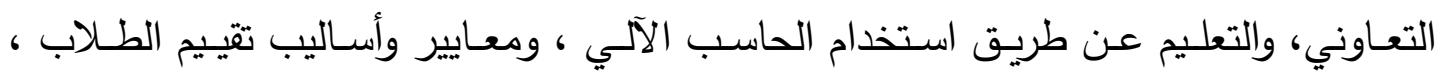
وسلوكيات المدرس في مجال التدري" دون محاولة فهم الأسباب التي قد تكون وراء نجاح مثل هذه الإستراتيجيات.

كذلك على ضوء الجدول (·r) السابق يتضح أن مؤشرات معيار التخطيط للدرس قد تحققت

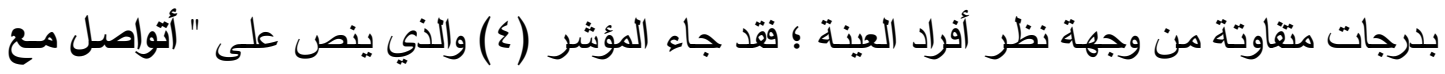
أولياء الأمور حول مستوى الطلاب " في المرتبة الأولى بمتوسط حسابي قدره (r. r. ) وهي نتيجة

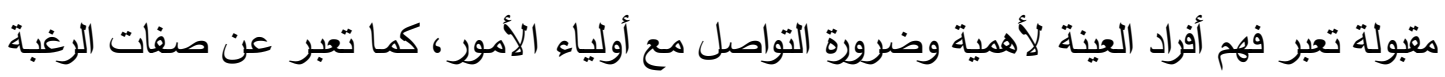

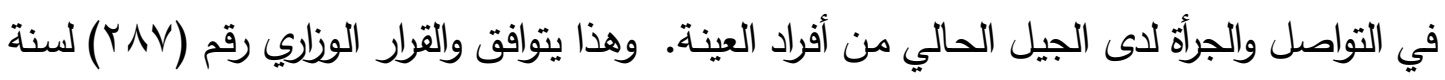
17 ومناشطهم ، وتحصيلهم الدراسي من خلال التواصل مع المدرسة. وقد جاء المؤشر (؟) والذي ينص على " أقدم استراتيجيات التقييم المناسبة للطلاب "

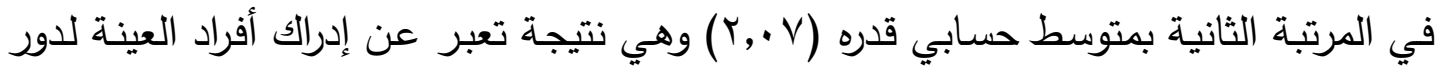

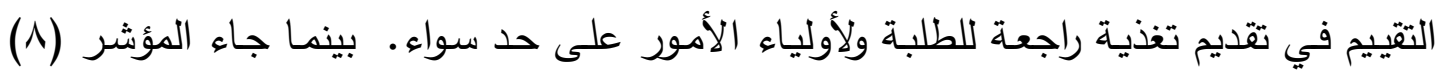

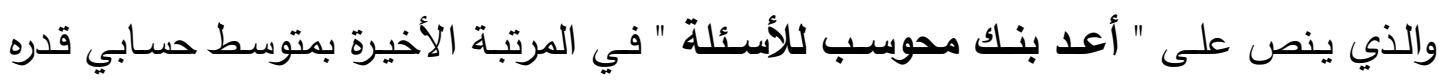

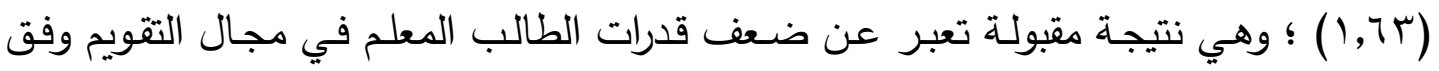

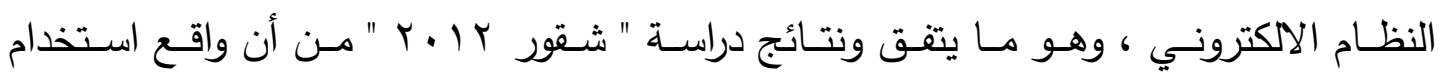

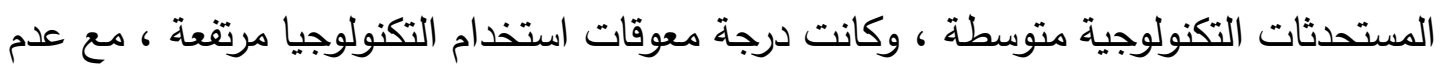

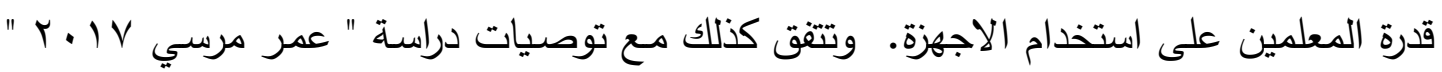
بضرورة تثجيع المعلمين على استخدام التكنولوجيا الحديثة في جوانب العملية التعليمية من خلال الحوار واللقاء مع المتخصصين في التكنولوجيا. 


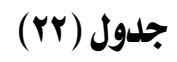

ترتيب ودرجة توفر مؤشرات معيار الأنشطة المدرسية من وجهة نظر العينة

\begin{tabular}{|c|c|c|c|c|c|c|c|c|c|c|}
\hline \multirow{2}{*}{ الترتيب } & \multirow{2}{*}{ النسبي } & \multirow{2}{*}{ المتوسط } & \multicolumn{2}{|c|}{ غير متوفر } & \multicolumn{2}{|c|}{ إلى حد ما } & \multicolumn{2}{|c|}{ متوفر } & \multirow{2}{*}{ 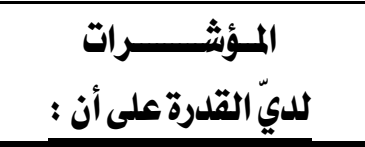 } & \\
\hline & & & $\%$ & تكرار & $\%$ & تكرار & $\%$ & تكرار & & \\
\hline$r$ & - vo & $r, r q$ & Y & 1... & $r \xi, \Lambda$ & 1.4 & 01,1 & rir & 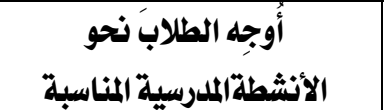 & \\
\hline 1 & צף & 1,94 & $T Y, O$ & $\| \varepsilon$ & 01,1 & rio & $r \cdot r$ & 19 & 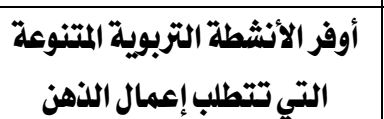 & \\
\hline 0 & $\cdot, 70$ & 1,97 & $r Y, O$ & $\| \xi$ & $\{\Lambda, \uparrow$ & $r \cdot r$ & $r, q$ & 99 & أحلح أنثطة متنوعة تراعي & \\
\hline r & $\cdot, \mathrm{rA}$ & $r, r q$ & $9, \xi$ & rq & «o & IAV & $\$ 0,0$ & 1199 & أوظف أنشطة تحفز على & $\xi$ \\
\hline $\mathrm{r}$ & $\cdot$, iv & 1,19 & $r r, r$ & 1 irs & $T \xi, 0$ & $1 \xi \%$ & $r r, r$ & ira & أبتكر أنثطة تربوية هادفة & \\
\hline$\xi$ & •, r. & $r, 11$ & 11,0 & vr & $\xi 9, \xi$ & rio & $r q, \uparrow$ & IrT & لتنفيذ الأنشطة قبل التدريس الألادوات & 9 \\
\hline 1 & •, $\wedge \xi$ & r,or & $r, q$ & 10 & $\xi, r$ & $17 \mathrm{r}$ & 07,1 & rer & أحلد أنشطة تعليمية ذات & \\
\hline
\end{tabular}

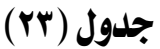

مستويات معيار الأنشطة المدرسية

\begin{tabular}{|c|c|c|}
\hline النسبةة٪ & التكرار & المستوى \\
\hline$r \cdot, \varepsilon$ & 10 & منخفض \\
\hline$\varepsilon r, 0$ & 187 & متوسط \\
\hline$r v, 1$ & 108 & مرتفع \\
\hline 1.. & $\$ 10$ & المجموع \\
\hline
\end{tabular}

يتضـح من جدول (rr) السابق أنه قد تم تقسيم معيار الأنثطة المدرسية إلى ثلاثة مستويات ( مرتفع - متوسط - منخفض ) وتبين أن (, م \% من العينة محور الدراسة تقع في

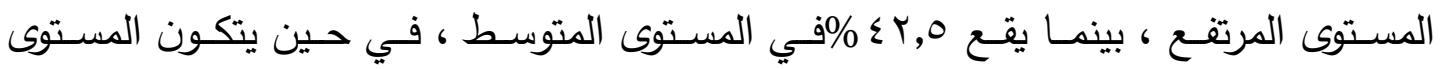

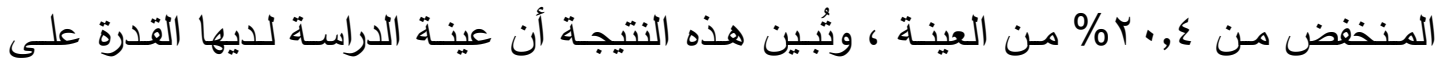
ممارسة الأنثطة الددرسية بدرجة متوسطة ؛ وقد يرجع ذلك إلى غياب الوعي بدور الأنثطة في العملية التعليمية، والذي اعتبرته الاتجاهات الحديثة في التربية جزءا رئيسا من المنهج بمفهومها 
الحديث، واعتمدت عليه اعتمادا كبيرا في بناء شخصية الطلاب معتقدة أن ثمة أهدافا لا تتحقق

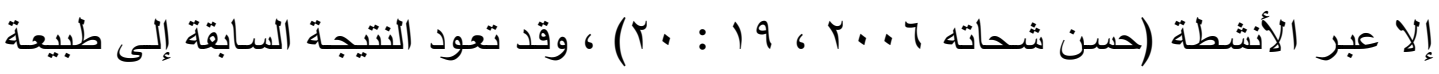

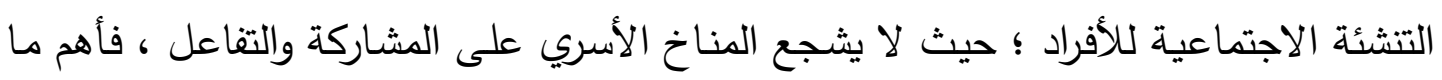

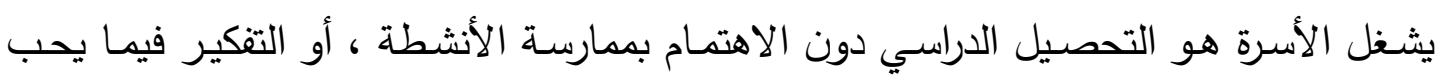
الطالب أن يمارسه ، وهو ما يتفق ودراسة " جمال السيسي ، وعلي نصار ؟ . . ؟ ".

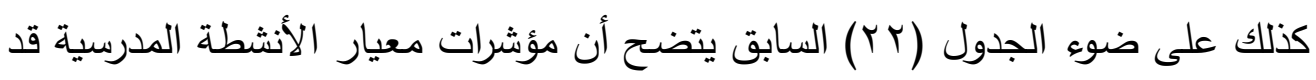

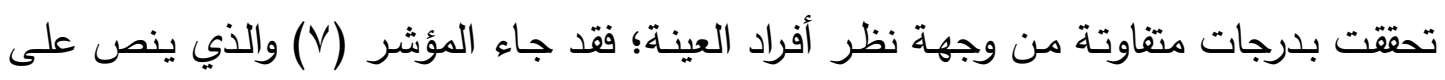
"أحدد أنثطة تعليمية ذات علاقة بموضوع الدرس" في المرتبة الأولى بمتوسط حسابي قدره

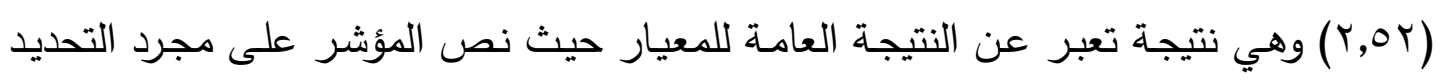
وليس التنفيذ.

وقد جاء المؤشر (ع) والذي ينص على " أوظف أنشطة تحفز على السلوك الإيجابي " في المرتبة الثانية بمتوسط حسابي قدره (79, (1) وهي نتيجة تعكس إدراك واهتمام أفراد العينة

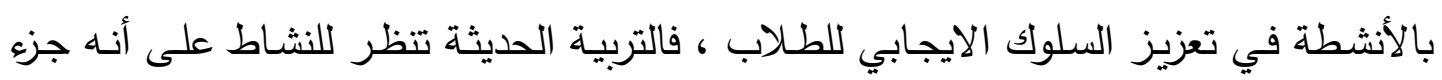
مهم في المنهج بمعناه الواسع الذي يترادف فيه المنهج مع الحياة المدرسية لتحقيق النمو الثامل

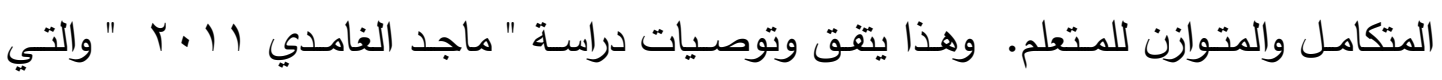
أوصت بضرورة تدريب المعلمين على التخطيط الجيد لتفعيل الأنثطة التعليمية أثناء العملية التعليمية نظرا لما لها من أهمية في تحقيق الأهداف التعليمية بأنواعها. وقد جاء المؤشر (0) والذي ينص على " أبتكر أنشطة تربويـة هادفـة " في المرتبة

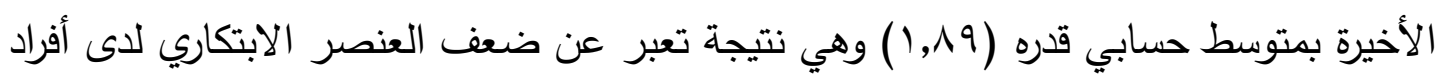

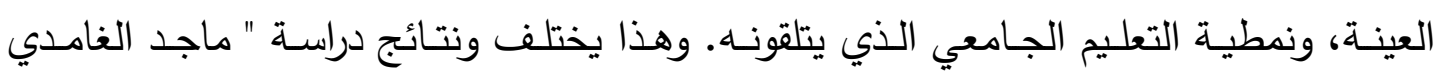

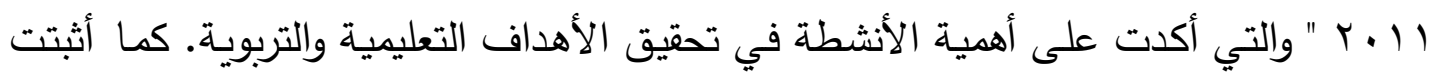
الدراسة فاعلية الأنثطة التعليمية في تتمية المهارات الحياتية للى الطلاب في كافة المجالات الاتهيه الاجتماعية ، والعلمية ، والصحية ، والبيئية. 


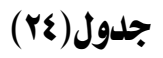

ترتيب ودرجة توفر مؤشرات معيار متطلبات ممارسة المهنة من وجهة نظر العينة

\begin{tabular}{|c|c|c|c|c|c|c|c|c|c|c|}
\hline \multirow{2}{*}{ الترتيب } & \multirow{2}{*}{ النسبي } & \multirow{2}{*}{ المتوسط } & \multicolumn{2}{|c|}{ غير متوفر } & \multicolumn{2}{|c|}{ إلى حلد ما إ } & \multicolumn{2}{|c|}{ متوفر } & \multirow{2}{*}{ 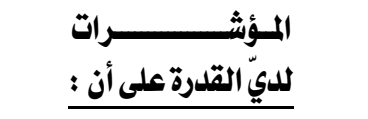 } & \multirow{2}{*}{ A } \\
\hline & & & $\%$ & تكرار & $\%$ & تكرار & $\%$ & 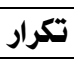 & & \\
\hline$r$ & •, ra & $r, r \wedge$ & $1 r, 0$ & or & $r q, 1$ & 10. & $01, r$ & & ألتزمب بسياسات الملدرسة & 1 \\
\hline$\xi$ & •, VA & r, rq & $r r, r$ & 00 & $r v, r$ & 100 & $\{9, \S$ & r.O & مسؤولية دعم تعليد الطلاب ألثولي & $r$ \\
\hline 0 & 政 & $1,9$. & $r \pi, r$ & $\mid r \Lambda$ & $\{r, q$ & IVA & $r r, q$ & 99 & 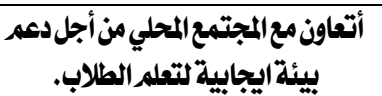 & $r$ \\
\hline$r$ & $\cdot, \wedge \cdot$ & r, & $10, r$ & Ir & $r q, 1$ & $|r|$ & $\Delta 0,7$ & rMI & أشارك بفاعلية في اللجان المدرسية & $\xi$ \\
\hline 1 & •,AY & r,§o & $\xi, q$ & r. & $\{\xi, \uparrow$ & 110 & 0,7 & $r$. & أبادر بالأشراف على المسابقات & 0 \\
\hline 7 & •, & I,Ar & $\{r, \xi$ & 187 & $r Y, Y$ & 159 & $r \xi, \Lambda$ & 1.4 & 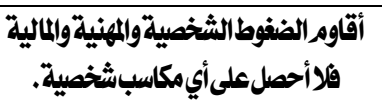 & 9 \\
\hline
\end{tabular}

جدول (ro)

مستويات معيار متطلبات مهارسة المهنة

\begin{tabular}{|c|c|c|}
\hline النسبة"\% & التكرار & المستوى \\
\hline$r \cdot r$ & $\Lambda \varepsilon$ & منخفض \\
\hline$r v, r$ & $10 \xi$ & متوسط \\
\hline$\{r, q$ & IVY & مرتفع \\
\hline 1... & $\$ 10$ & المجموع \\
\hline
\end{tabular}

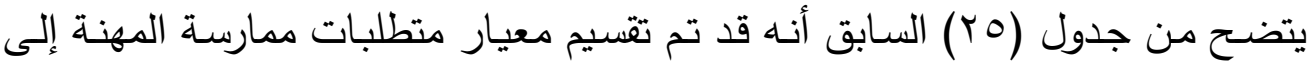
ثلاثة مستويات ( مرتفع - متوسط - منخفض ) وتبين أن T,rع \% من العينة محور الدراسة

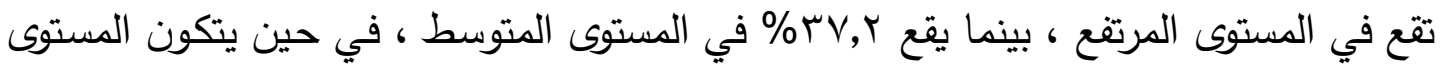

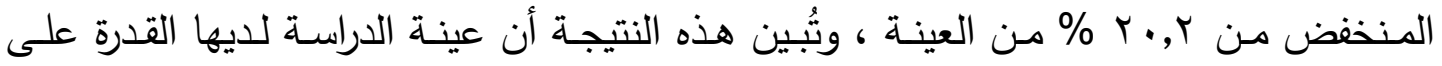

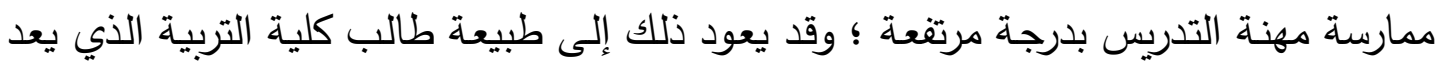
نفسه منذ دخوله الجامعة ، وينظر لها مهنيا على أنه معلم.

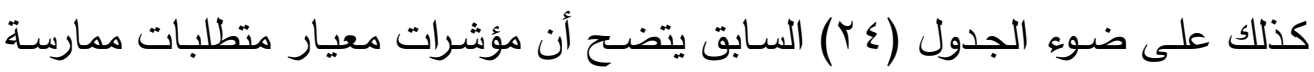

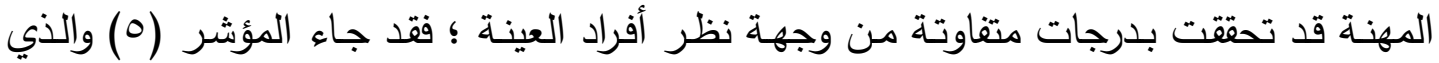

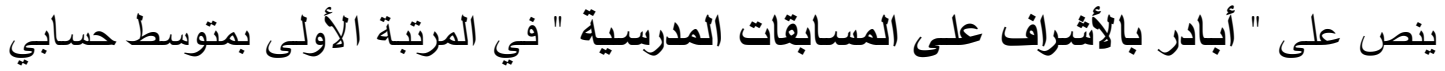

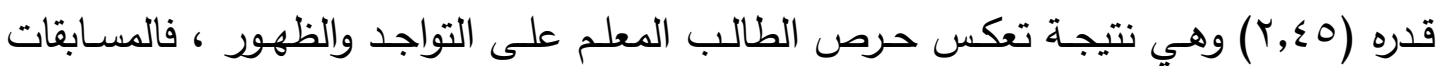
المدرسية وسيلة لانتثار المعلم وإلقاء الضوء عليه في مجتمعه المدرسي. 


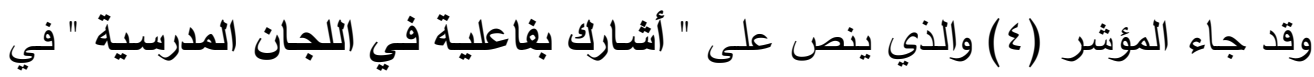

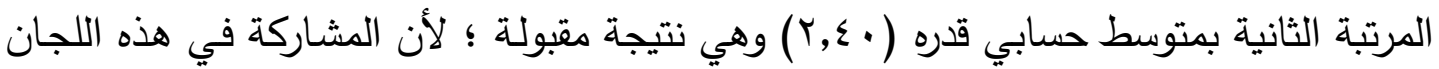

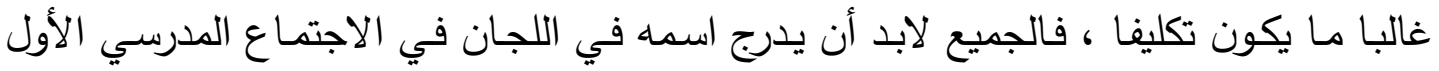

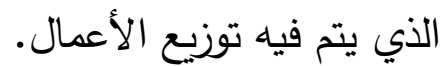

وقد جاء المؤشر (؟) والذي ينص على " أقاوم الضغوط الثخصية والمهنية والمالية

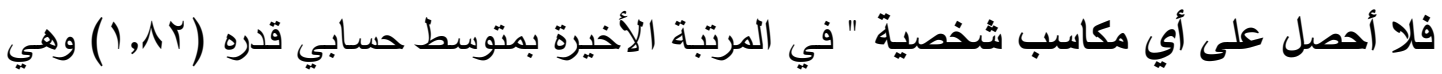

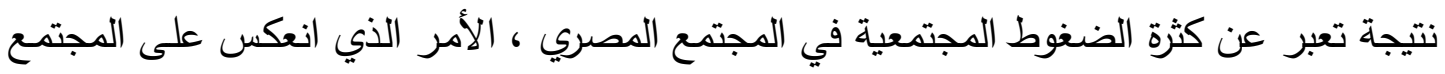
الجامعي فتأثر به أفراد العينة لارجة عدم قدرتهم على مواجهة الضغوط بأثكالها الثخصية والمهنية والمالية أمام بعد المكاسب الثخصية ، وهذا لا يثك ينذر بخطر أخلاقي كبير.

جدول (r)

ترتيب ودرجة توفر مؤشرات معيار التنمية المهنية الذاتية منوجهة نظر العينة

\begin{tabular}{|c|c|c|c|c|c|c|c|c|c|c|}
\hline \multirow{2}{*}{ الترتيب } & \multirow{2}{*}{ الن الوزب } & \multirow{2}{*}{ المتوسط } & \multicolumn{2}{|c|}{ غير متوفر } & \multicolumn{2}{|c|}{ إلى حلد ما } & \multicolumn{2}{|c|}{ متوفر } & \multirow{2}{*}{ 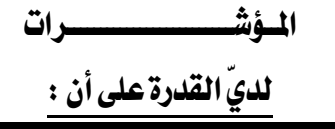 } & \multirow{2}{*}{ A } \\
\hline & & & $\%$ & التكرار & $\%$ & التكرار & $\%$ & التكرار & & \\
\hline$r$ & •, 79 & 1,99 & $r, o$ & $1+r 9$ & $r r, o$ & $1 \% q$ & rr & Irr & أشارك في أنشطة التنمية & 1 \\
\hline$r$ & •, 97 & 1,99 & $r r, Y$ & 180 & $r r, r$ & $\mid r A$ & $\mu$ & ITr & أربط بين أنشطة التنمية الهنية & $r$ \\
\hline r & $\cdot, \mathrm{V} \varepsilon$ & $r, r r$ & rq & $1 \cdot 1$ & $r o, 1$ & $1 \cdot v$ & $\{\Lambda, r$ & r.. & أستقيد من خبرات المعلمين القدامى & $r$ \\
\hline 0 & $\cdot, 00$ & $1,7 v$ & 01,7 & MI & $r q, q$ & irr & 11,1 & vi & أمارس الاطلاع الحر & $\xi$ \\
\hline 1 & •, vई & $r, Y \xi$ & TY & IIT & $Y, Y$ & 9. & $01, r$ & rir & للاطلاععلى المستجدات في تخصصيائل التكنولوجيا & 0 \\
\hline$\xi$ & •, 79 & 1,91 & $r \xi, q$ & 180 & $\Gamma 1, \Lambda$ & Irr & $r, r$ & 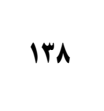 & أشارك في الندوات والمؤتمرات & 1 \\
\hline
\end{tabular}

جدول (YV)

مستويات معيار التنمية المهنية الذاتية

\begin{tabular}{|c|c|c|}
\hline النسبة\% & التكرار & المستوى \\
\hline$\lceil\xi, \xi$ & | & منخفض \\
\hline$r q, r$ & $|T|$ & متوسط \\
\hline$r 9, r$ & 101 & مرتفع \\
\hline 1... & $\$ 10$ & المجموع \\
\hline
\end{tabular}


يتضح من جدول (rV) السابق أنه قد تم تقسيم معيار التنمية المهنية الذاتية إلى ثلاثة

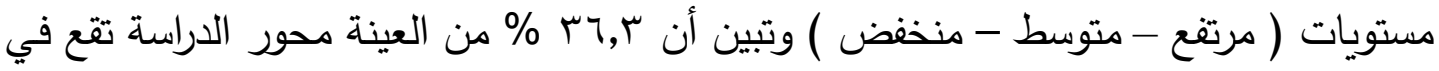

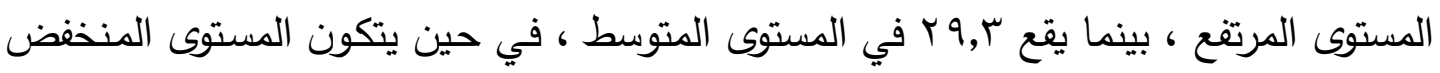

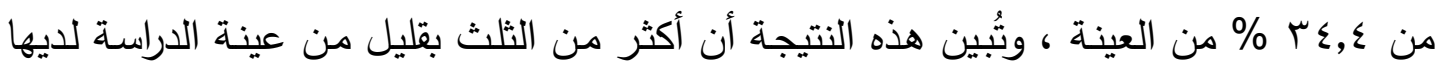

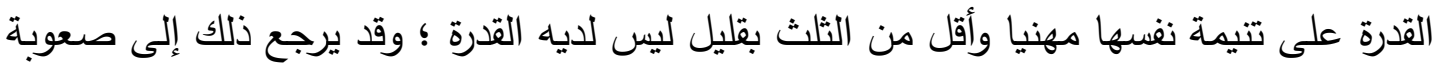
وتعقد قضية التتمية المهنية الذاتية ، وكثرة أدوار المعلم في مجتمع المعرفة ، كما تعبر النتيجة

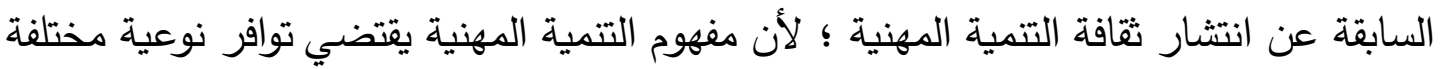
من التفكير للى المعلمين، تختلف عن نوعية الأفكار والسلوكيات التقليدية وهذا يتفق ودراسة

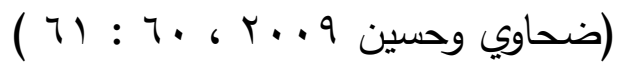

كذلك على ضوء الجدول (Tr) السابق يتضح أن مؤشرات معيار التتمية المهنية الذاتية

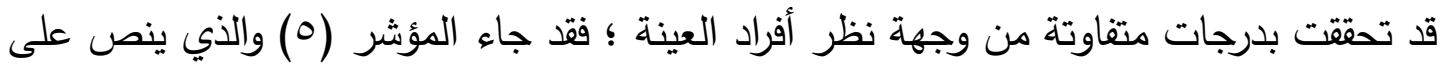

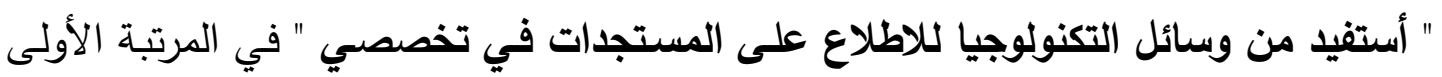

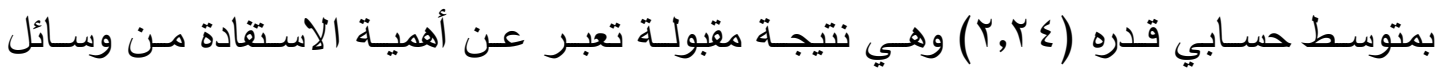

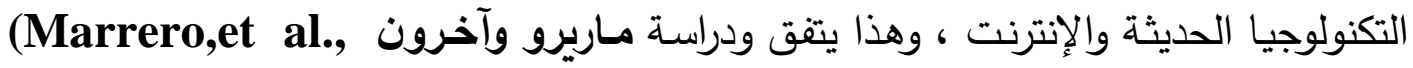
( 2010 والتي خلصت إلى أن الدورات التدريبية القصيرة على الإنترنت تلعب دورا كبيرا في تطوير أداء المعلمين مهنيا. وقد جاء المؤشر (r) والذي ينص على " أستفيد من خبرات المعلمين القدامى " في

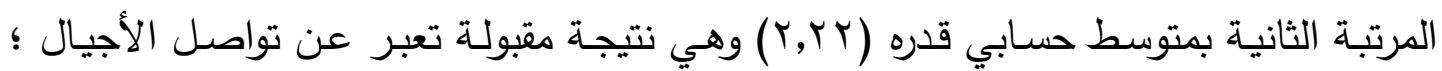

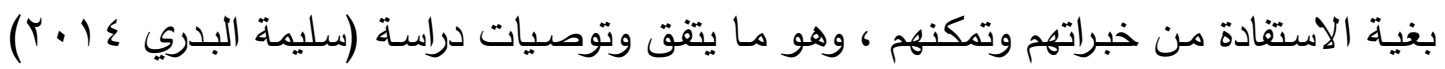

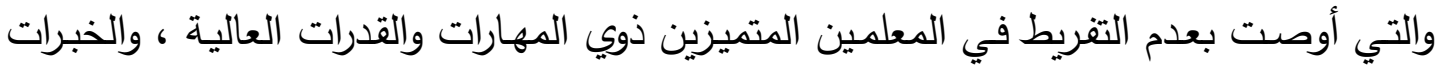
الغنية بتحويلهم إلى وظائف إدارية، أو هامشية، وإنما إحتوائهم والإحتفاء بهم واستبقائهم كخبراء

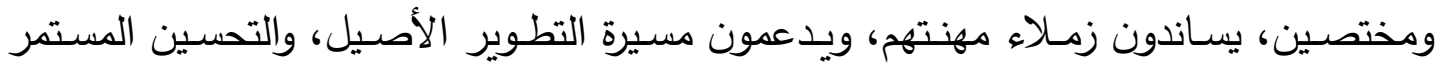

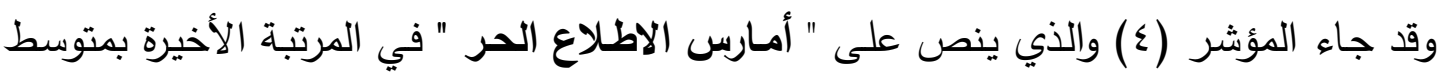

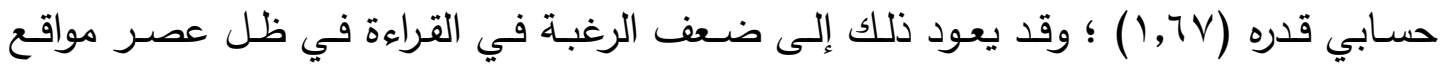

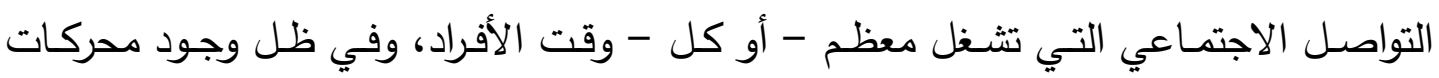

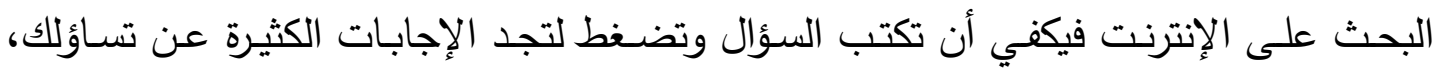




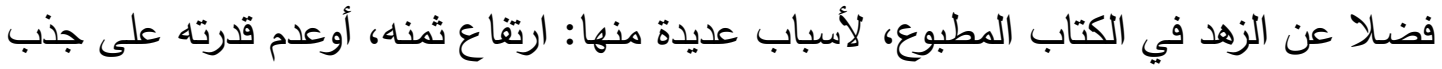

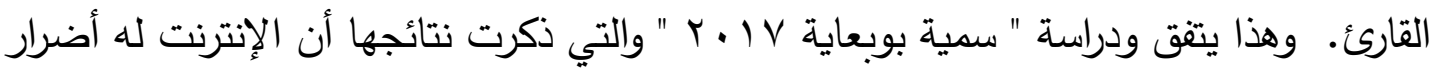

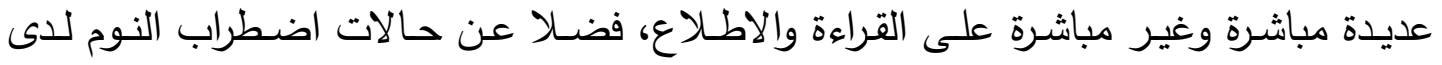

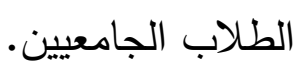

\section{نت نـائج الـدراسـة:}

توصلت الاراسة الراهنة للنتائج التالية:

تحققت معايير الدراسة من وجهة نظر الطلبة المعلمين أفراد عينة الدراسة بدرجة متوسطة

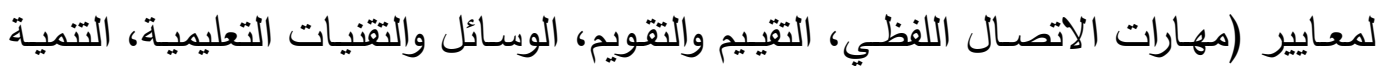

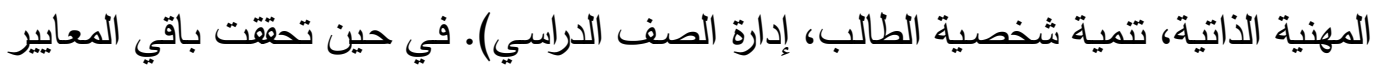

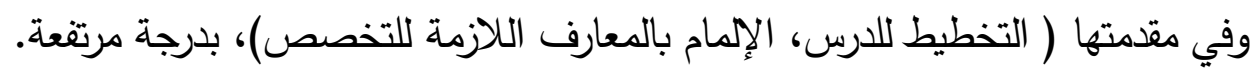

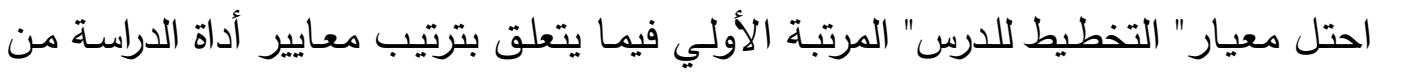

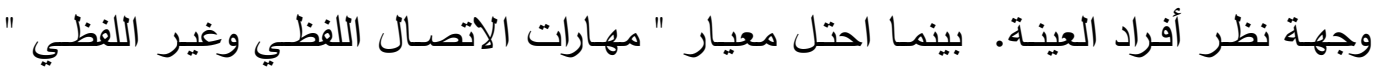
المرتبة الأخيرة كما ذكر أفراد العينة.

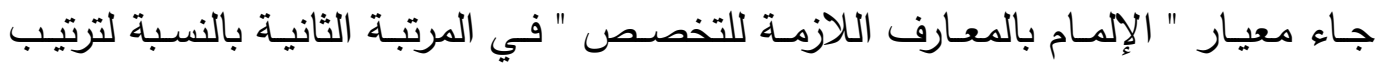
معايير الدراسة بدرجة مرتفعة من وجهة نظر أفراد العينة. • أن عينة الدراسة لديهم القدرة على القيام بالتقييم والتقويم لتلاميذهم بدرجة متوسطة. • أن عينة الدراسة لديها القدرة على توظيف طرائق التدريس لتحقيق أهداف التعلم بدرجة متوسطة. • أن عينة الدراسة لديها القدرة على مهارات الاتصال اللفظي وغير اللفظي بدرجة ضعيفة.

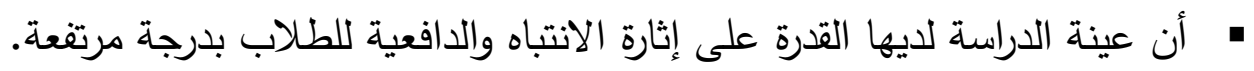
• أن عينة الدراسة لديها القدرة على تتمية شخصية الطالب بدرجة متوسطة.

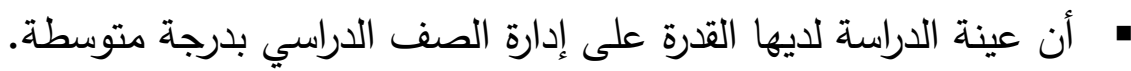
• أن عينة الدراسة لديها القدرة على استخدام الوسائل والتقنيات التعليمية بدرجة مرتفعة. • • أن عينة الدراسة لايها القدرة على التخطيط للدرس بدرجة متوسطة. • أن عينة الدراسة لايها القدرة على استخدام الأنثطة المدرسية بدرجة متوسطة. • أن عينة الدراسة معدة ولديها القدرة على ممارسة مهنة التدريس بدرجة مرتفعة. • • أن عينة الدراسة لايها القدرة على تتيمة نفسها مهنيا بدرجة مرتفعة. 


\section{التصور المقترح لتطوير الإعداد المهني للطالب المعلم بجامعتي أسيوط والسادات}

\section{في ضوء معايير التنمية البشرية :}

في ضوء الإطار النظري الذي تم عرضه، وفى ضوء ما توصلت إليه الدراسة الراهنة

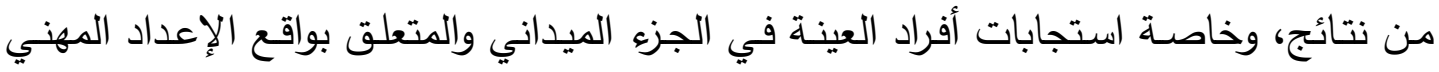

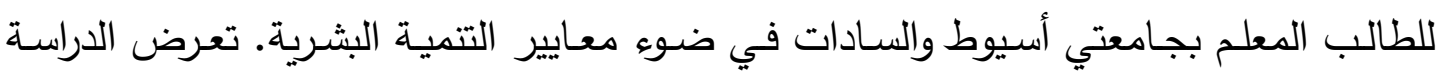
الراهنة فيما يلي الظهير الفلسفي لهذا التصور ، وأهم الأهداف التي يسعى لتحقيقها، ومنطلقاته، وعناصره، بجامعتي أسيوط والسادات والمتطلبات الواجب توافرها حتى يمكن تحقيقه.

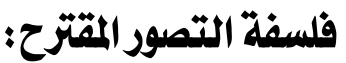

ينطلق التصـور المقترح لتطـوير الإعـداد المهني للطالب المعلم بجـامعتي أسيوط

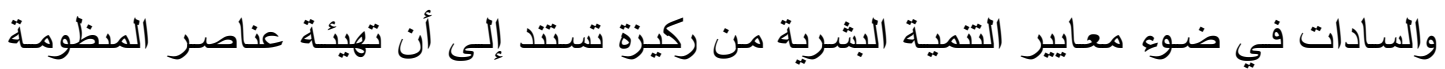

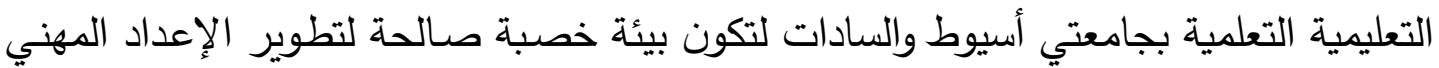
للطالب المعلم يتطلب إحداث تغيرات جذرية في مختلف العناصر الفاعلة في تلك المنظومة من خلال تبني الرؤى الفلسفية التالية:

تبنى الفكرة الأساسية لـفهوم الإعداد المهني للطالب وفق معايير التتمية البشرية. نشر ثقافة قبول معايير التتمية البشرية وضمانها في مؤسسات الإعداد بجامعتي أسيوط الإدانية

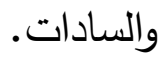

إعداد دليل إرشادي بمعايير ومؤشرات التتميـة البشرية للطالب المعلم في مؤسسـات الإعداد بجامعتي أسيوط والسادات. " النظر إلى الجامعة كبناء اجتماعي قادر على صنع مَن يصنعون الأفراد الصالحين في الإدي

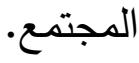

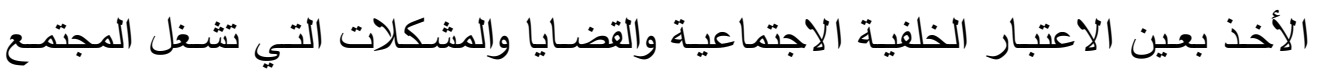
المصري، وتتعكس على جميع عناصر المظومة التعليمية التعلمية.

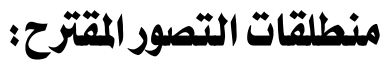

يرتكز التصور المقترح على جملة من المنطلقات المحلية والعالمية يمكن عرضها في:

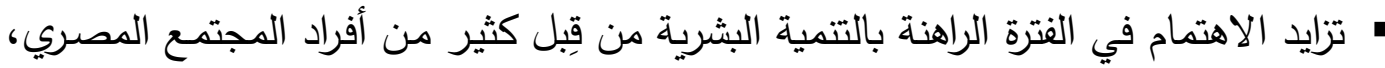

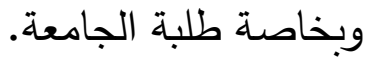


الرغبة المستمرة في النهوض بالطالب المعلم، ويظهر ذلك في العديد من المؤتمرات والندوات التي تنظمها كليات التربية والجامعات المصرية.

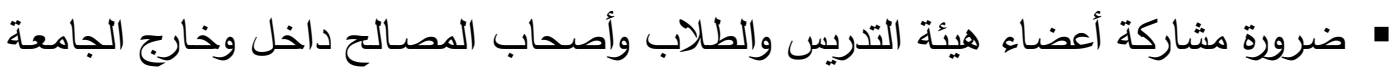
في صياغة أهداف المقررات الجامعية الداعمة لإعداد الطالب المعلم وفق معايير التتمية

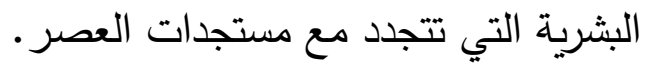

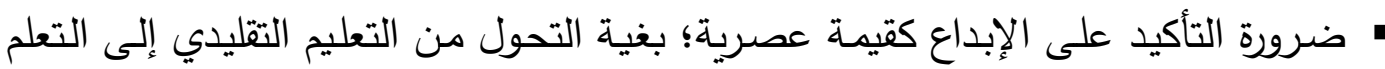

$$
\text { الإبداعي العصري }
$$

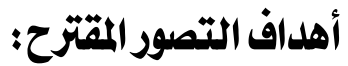

لتطوير الإعداد المهني للطالب المعلم بجامعتي أسيوط والسـادات في ضوه معايير التنمية البشرية يسعى التصور المقترح إلى تحقيق الأهداف الآتية:

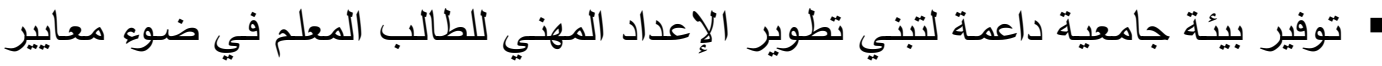
التتمية البشرية داخل كليات التربية بجامعتي أسيوط والسادات. • مواكبة معايير التتمية البشرية الحديثة عند إعداد الطالب المعلم بجامعتي أسيوط والسادات.

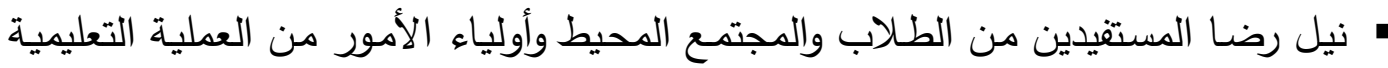
داخل مؤسسات جامعتي أسيوط والسادات بمختلف متطلباتهر.

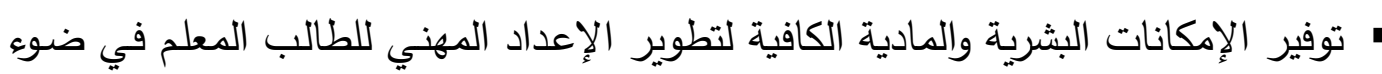

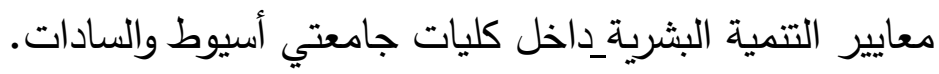
التوظيف الجيد والفعال للتكنولوجيا ومستحدثاتها في النواحي التعليمية التعلمية بجامعتي التئي

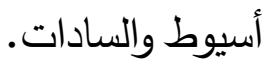
" إيجاد مناخ داعم للمشاركة المجتمعية داخل جامعتي أسيوط والسادات.

\section{عناصر التصور المقترح :}

يمكن عرض العناصر التي تساعد في تطوير الإعداد المهني للطالب المعلم في ضوء

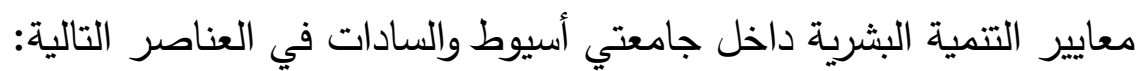

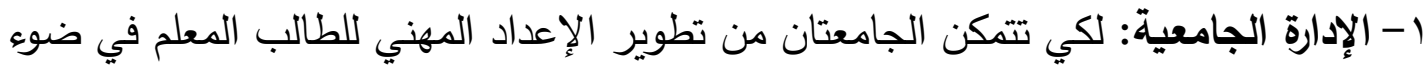

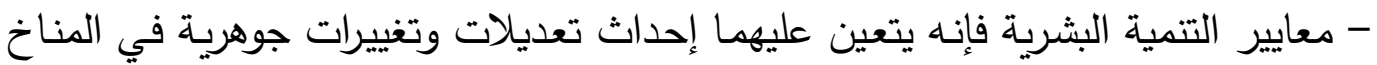


العلمي والفكري والإداري والوطني بهها؛ حيث إن النمط الإداري هو المسئول عن توفير المناخ الإنساني والاجتماعي الذي يعلي من قدر الطالب المعلم، ويشيع القيم الإنسانية

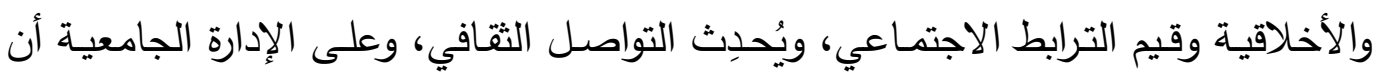

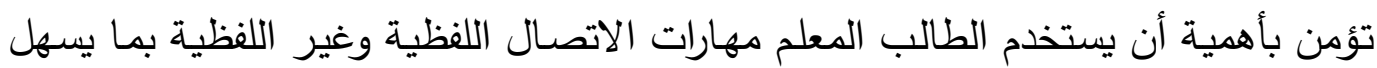
عملية التعليم، ويحقق الأثر المطلوب، وعليها كذلك أن تعمل على تتمية شخصية الطالب البهال

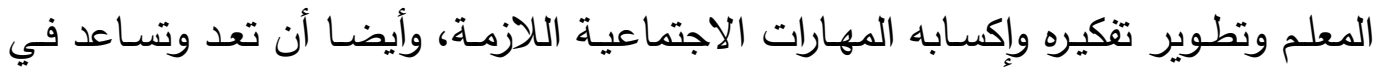

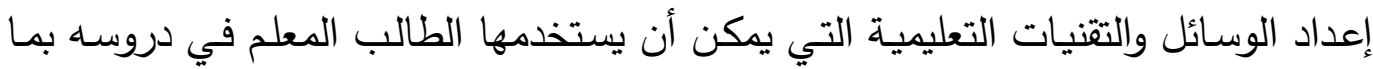

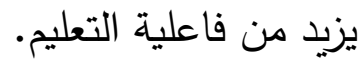
r- الأنثطة الطلابية: تعتبر الأنشطة الطلابية مجالا أساسيا لإثراء معلومات الطالب المعلم وخبراته العلمية والعملية ، وتحقيق التواصل بينه وبين زملائه وأساتذته، وإكسابه المهارات

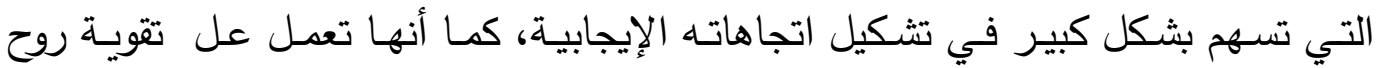

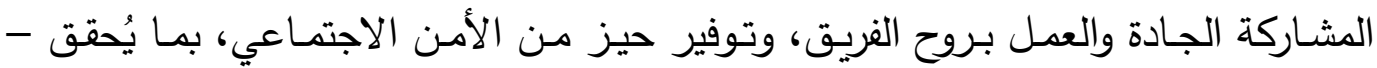

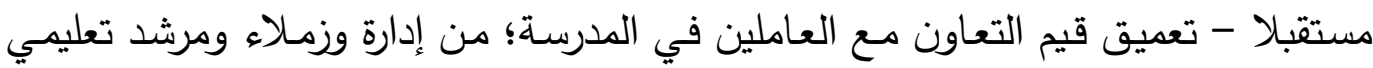

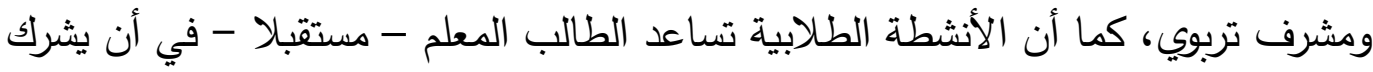
طلابه في عملية التعلم باستخدامه للمهارات والاستراتيجيات التي تساعد على إثارة التابط الانتباه

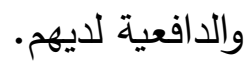

وتعتبر الاتحادات الطلابية من أهم أشكال التنظيمات الطلابية التي تستهدف تتشئة الطلاب على مفاهيم السياسة وقيم المواطنة ، هذا إلى جانب تأثير التظيمات الطلابية في قيم واتجاهات الطلاب السياسية ، ومبادئ المشاركة في إدارة حياتهم الدراسية في الجامعة.

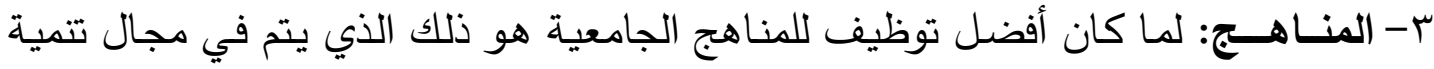
الموارد البشرية، ولما كان الطالب المعلم يمثل ثروة وطنية في غاية الأهمية، لذا يجب على لهى المؤسسات التعليمية وفي مقدمتها الجامعات أن تسعى لدراسة حاجاته وطرق تتميته وتحفيزه ووضع البرامج المناسبة له؛ وذلك لأن آمالا كبرى تتعقد علي الطالب المعلم.

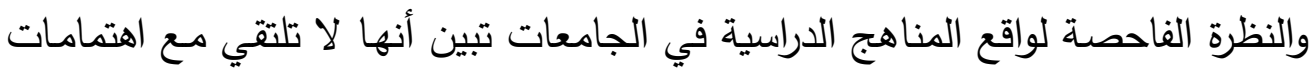
الثباب، ولا تقوم بالرد على استفساراتهم وتساؤلاتهم وتفسير الظواهر التي تحيط بمجتمعهم، وبالتالي فهي لا تساعدهم على فهم واقعهم فهما موضوعيا، مما يؤدى بهم إلى كبت قدراتهم 
الإبداعية وملكاتهم العقلية عن الإسهام في تطوير العمليات البنائية في المجتمع. ولكي تسهم المناهج والمقررات الدراسية في تطوير الإعداد المهني للطالب المعلم لا غنى عن اعتماد التعليم التعاوني لما يوفره من تفاعل اجتماعي يؤدى إلى اكتساب القيم المرغوبة اجتماعيا، مع المواءمة

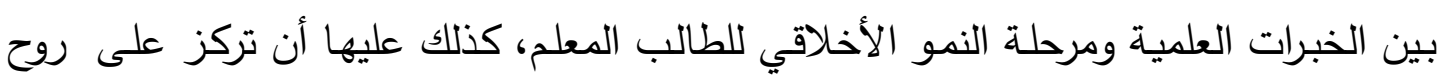

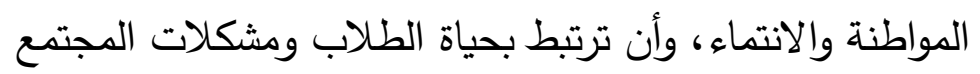

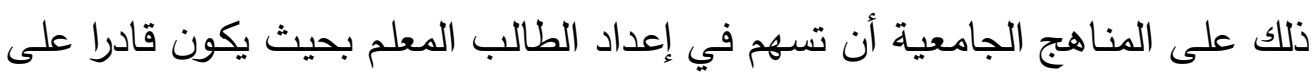

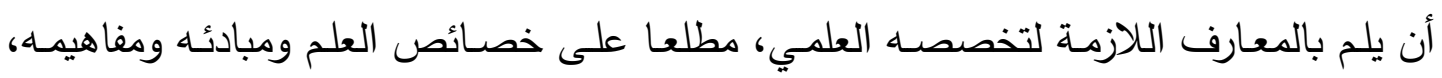

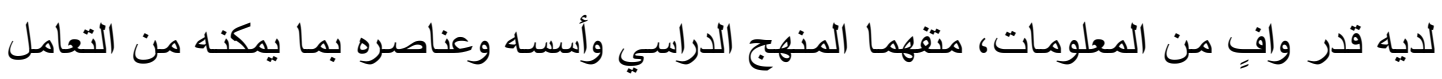

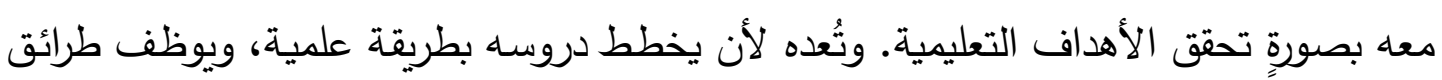
تدريس متتوعة تتوافق مع عناصر عملية التعلم، وتحقق أهدافها. ع - الأستاذ الجامعي: يعد الأستاذ الجامعي العنصر الأساسي والجوهري في في العملية التهافي التعليمية

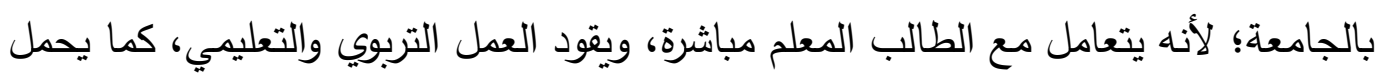
الأستاذ الجامعي رسالة الجامعة العلمية والعملية في خدمة المجتمع وتحقيق أهدافه. ويمكن لأنس للأستاذ الجامعي الإسهام في تطوير الإعداد المهني للطالب المعلم في ضوه معايير التتمية

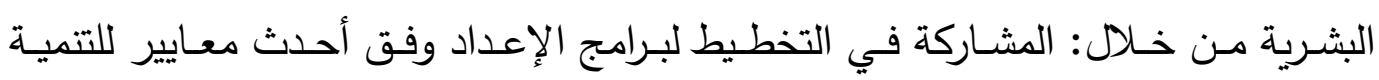
البشرية. الإسهام في توفير المناخ التربوي والتعليمي الملائم للطالب المعلم لتربية الحريـة العقلية داخل وخارج قاعات الدراسة. توظيف النشاط غير الصفي. تدريب الطالب المعلم

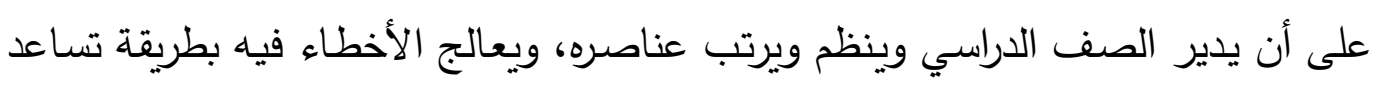
على زيادة تحصيل المتعلمين وتتمية شخصياتهم.

\section{متطلبات تحقيق التصور المقترح :}

لتطوير الإعداد المهني للطالب المعلم في ضوء معايير التتمية البشرية داخل جامعتي أسيوط والسادات توجد مجموعة من المنطلبات التي تساعد في تحقيق ذلك بالمؤسسات التعليمية

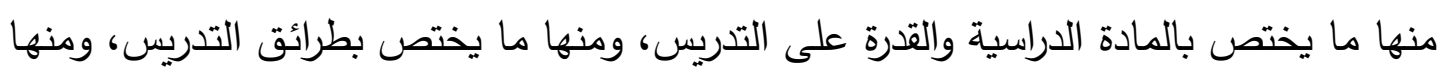

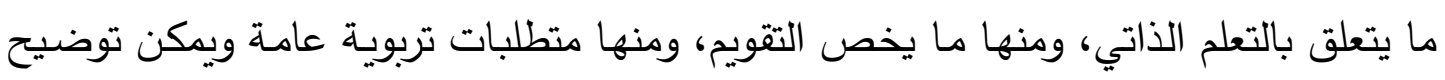


ذلك فيما يلي :

1 - متطلبات خاصة بالمادة الدراسية والمقرر، وتتضمن إعداد الطالب المطلم بحيث يتمكن من:

$$
\text { • القدرة على تحديد أهداف الدرس. }
$$

توظيف المحتوى الدراسي ليخدم القضايا والمشكلات التي تخص المجتمع. عرض المحتوى الدراسي بما يتلاءم وطبيعة الحياة المعاصرة وعصر المعرفة. ه القدرة على صياغة الأهداف سلوكيا. “تظيم عناصر الدرس بصورة مترابطة.

الاهتمام بالجانب التطبيقي مع ضرورة تكامله مع المواد النظرية.

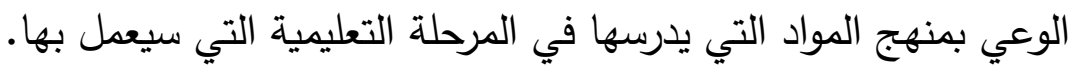
تحديد المادة التعليمية المناسبة لأهداف الدرس.

ץ - متطلبات خاصة بطرائق التدريس ، وتتضمن إعداد الطالب المعلم بحيث يتمكن من: مهارة استخدام الطرق الحديثة في التدريس.

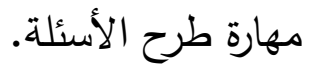

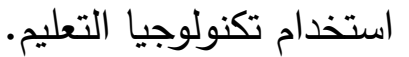
ه القدرة على تحويل المحتوى التعليمي إلى نشاطات تعليمية. ربط المعلومات السابقة بالجديدة وربطها جميعًا بالحياة. الاستفادة من التغذية الراجعة.

ץ- متطلبات خاصة بالتعلم الذاتي ، وتتضمن إعداد الطالب المعلم بحيث يتمكن من :

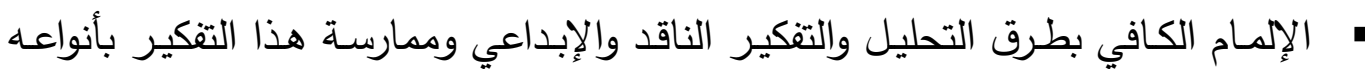
خلال تدريسه في حجرة الدرس أثناء التربية العملية وما بعدها. " القدرة على تدريب التلاميذ على مهارة الحصول على المعرفة من مصادرها. " السعي المستمر إلى الاحتفاظ الدائم بالمعارف الحديثة والجديد منها. ع - متطلبات خاصة بالتقويم ، وتتضمن إعداد الطالب المعلم بحيث يتمكن من : هإتقان استخدام أساليب التقويم المختلفة والتكنولوجية منها على وجنه الخصاد الخصوص.

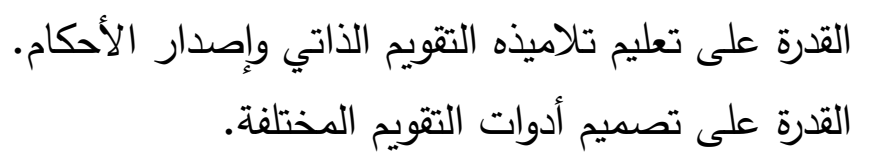


الوعي بأهمية التقويم كوسيلة للتحقق من مدى نجاح طريقته في التدريس. ه - متطلبات تربوية عامة ، وتتضمن :

فهم خصائص الطالب المعلم في السنوات الدراسية الأربع. تشجيع عملية التفاعل في المحاضرة بين الطلاب أنفسهم وبينهم وبين الأستاذ الجامعي. استخدام طرق الثواب والعقاب وفق أصولها التربوية والنفسية. الاهتمام بالثقافة العامة المحيطة بالطالب المعلم.

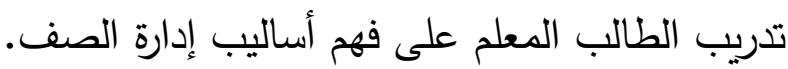

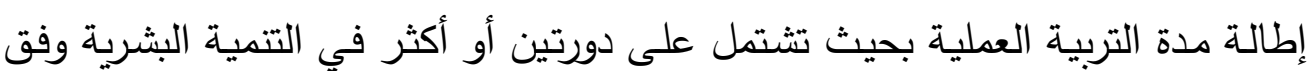
المعايير الواردة بالدراسة.

يرى كثير من الباحثين أن هذا العصر الذي يطلق عليه عصر المعلوماتية يفرض أن يتم إعداد المعلمين في المؤسسات التعليمية ، بحيث يتم التركيز على استخدام التقنيات

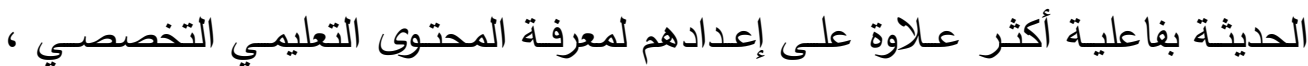
والمعرفة التربوية ، والإعداد العام. توفير برامج تمكن الطالب المعلم من وضع مـا اكتسبه من معارف إنسانية ومفاهيم

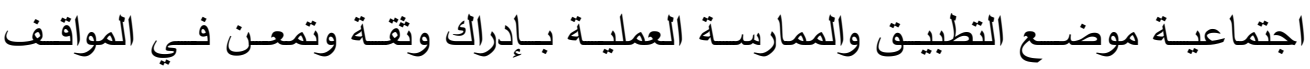
والمعضـلات التربويـة المتعددة التي تحدث في المدرسة وفي حجرة الدرس وتلك التي

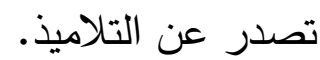
إعداد برامج تسـاعد على تكوين وصياغة معلم مدرك ومتعلم ومـاهر ومثقف ثقافـة ناضـة لأداء وظيفـة محددة تختص بالتربيـة والتعليم ، لذا ينبغي النظر إلى عمليـة

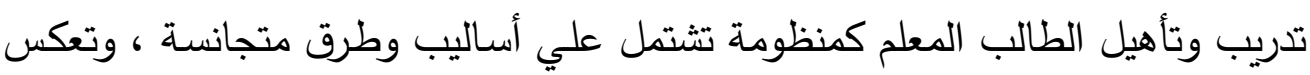
في ذات الوقت الأطر والخصائص الثقافية والعقائدية والاجتماعية للنظام التعليمي. 


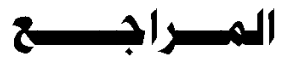

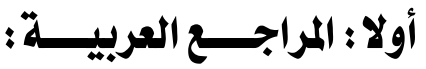

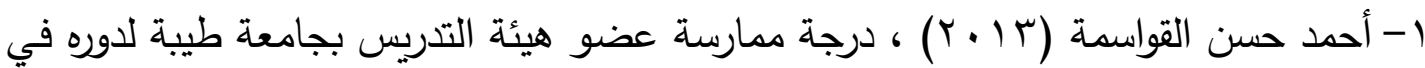

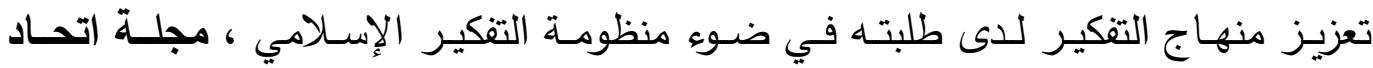

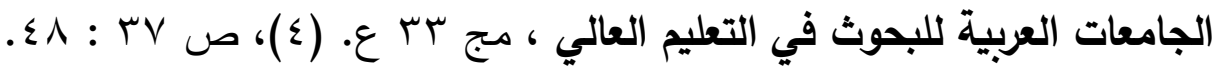

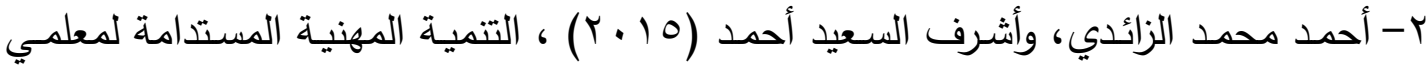
المدارس الثانوية بمحافظة جدة في ضوه متطلبات معايير الاعتماد المهني تصور مقترح، مجلة مستقبل التربية العربية, مجr ب, عـ 9.

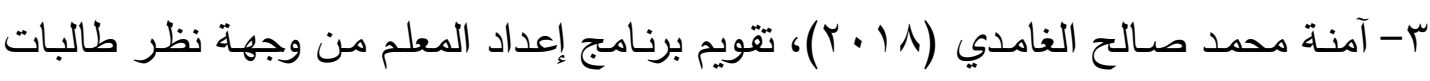

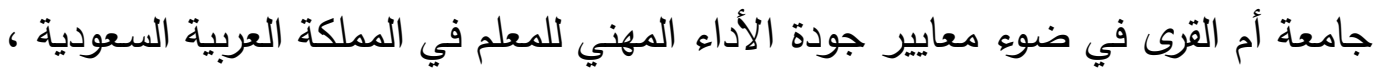

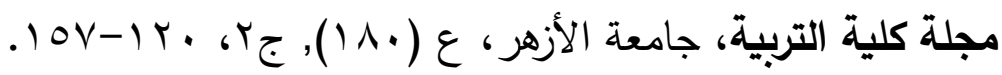

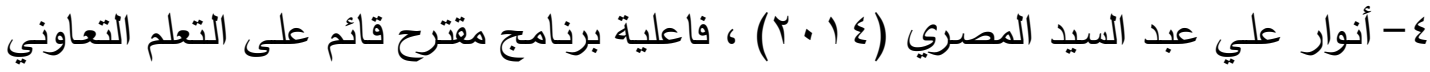
في تنميـة مهارات تخطيط الدرس لدى طالبات الاقتصـاد المنزلي بكلية التربيـة النوعية.

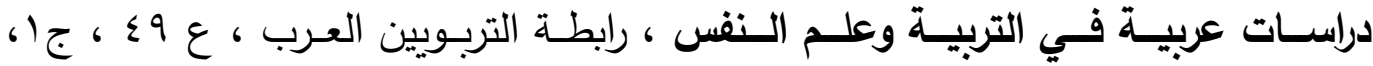
ص : : 149

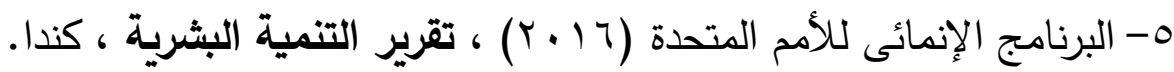

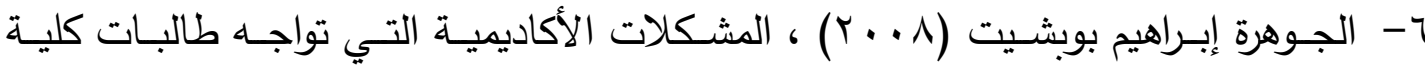
الدراسات التطبيقية وخدمة المجتمع بجامعة الملك فيصل من وجهة نظرهن ، مجلة جامعة التها

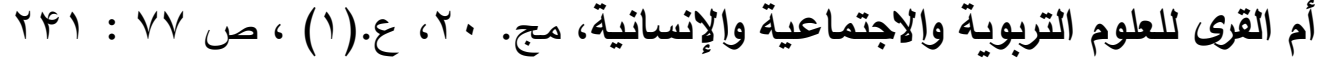

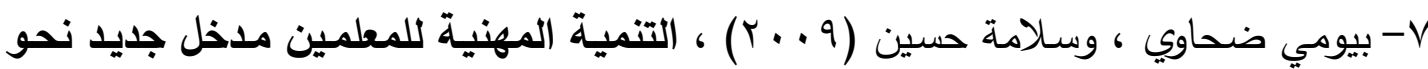

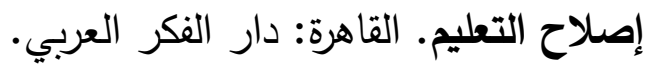

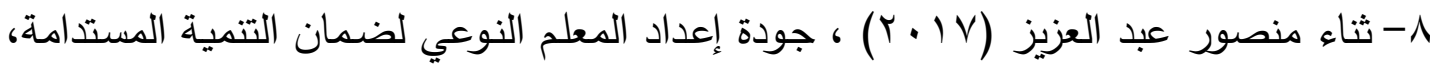

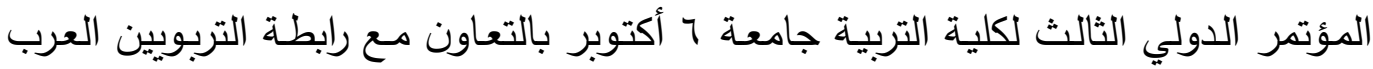
بعنوان: مستقبل إعداد المعلم وتتميته في الوطن العببي، جامعة 7 أكتوبر - كلية التربية ورابطة التربوين العرب والأكاديمية المهنية للمعلمين، بحث منشور بمجلة دراسـات عربية

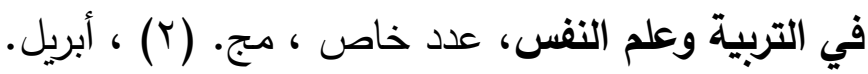


9- تيسير النعيمي (• ( †) ، معايير التميز في مراكز التتمية المهنية للمعلمين في المنطقة

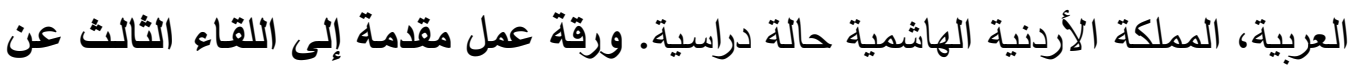

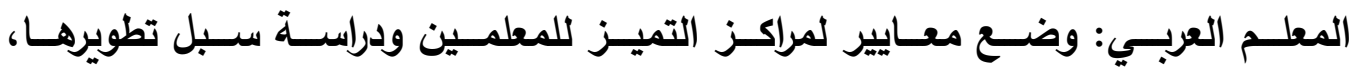

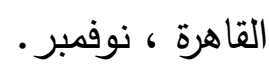

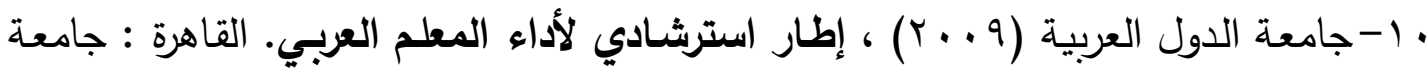

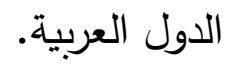

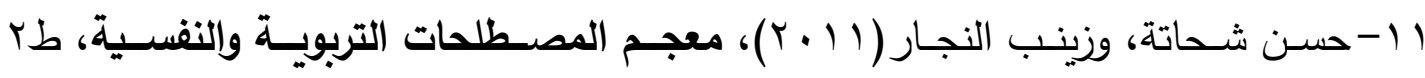
القاهرة:الدار اللبنانية المصرية.

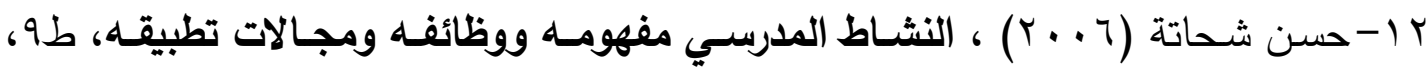
القاهرة ، الدار المصرية اللبنانية.

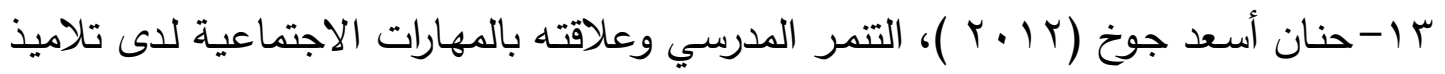

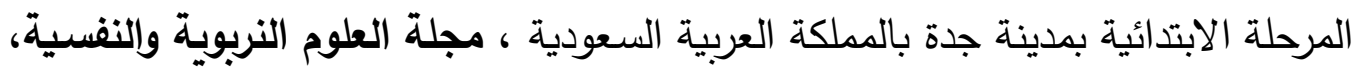

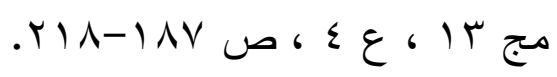

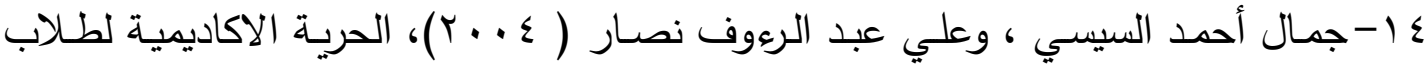

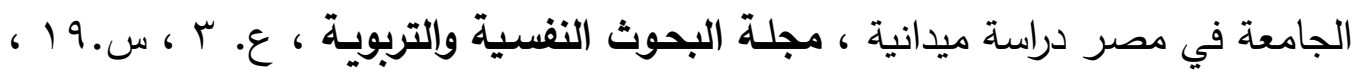
كلية التزبية ، جامعة المنوفية.

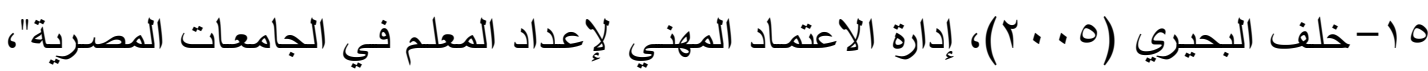

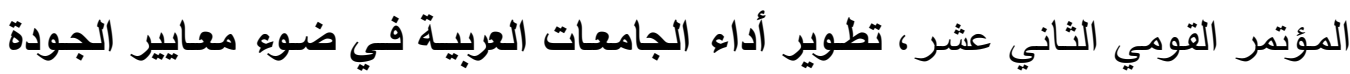
الثاملة ونظام الاعتماد، القاهرة، ديسمبر .

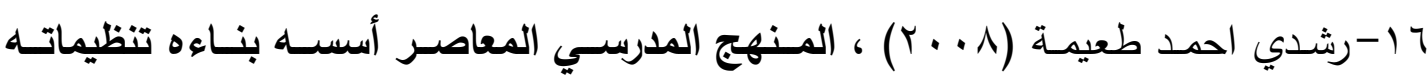
تطويره، عمان: دار المسيرة.

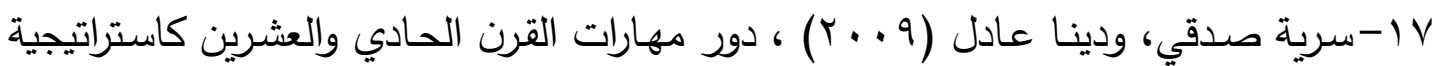

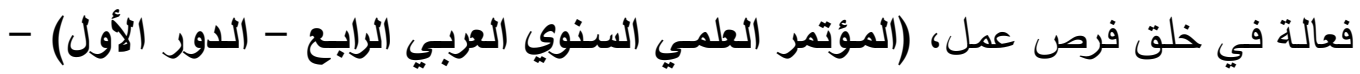

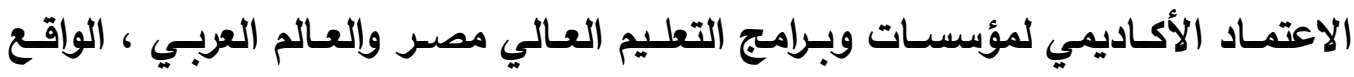
والمأمول، كلية التربية النوعية، جامعة المنصورة.

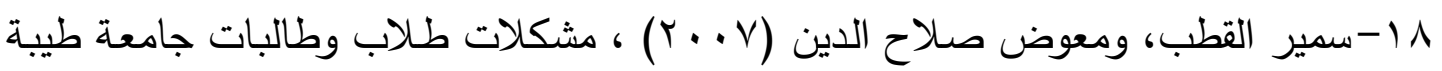

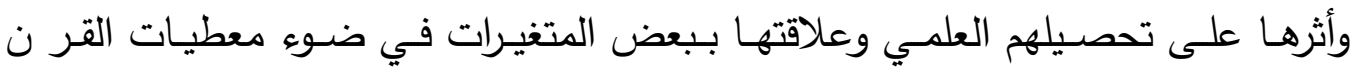

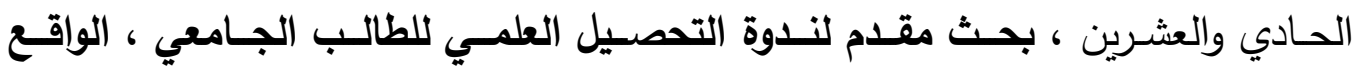
والطموح، جامعة طيبة ، المدينة المنورة. 
9 1-سمية بوبعاية (Y V V V) ، الإدمان على الإنترنت وعلاقته بظهور اضطرابات النوم لدى

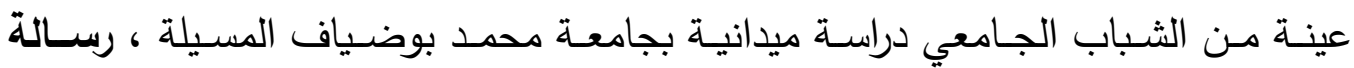
ماجستير ، كلية العلوم الإنسانية والاجتماعية ، جامعة محمد بوضياف.

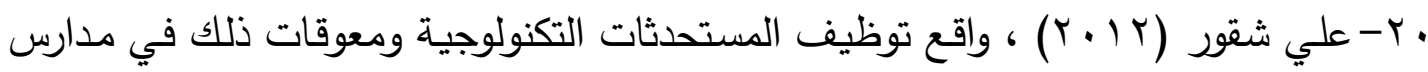

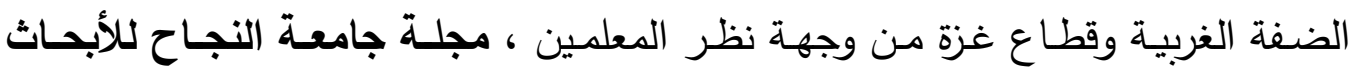

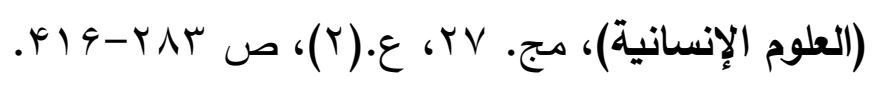

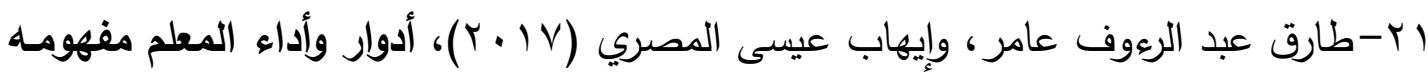
- أهدافه ، القاهرة : طيبة للنشر والتوزيع.

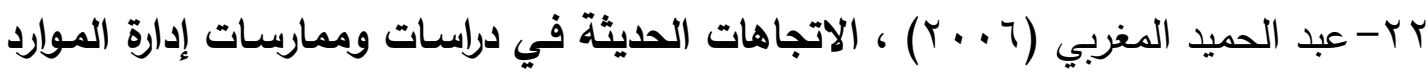
البشرية، المنصورة : المكتبة العصرية.

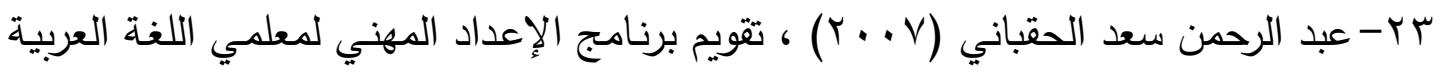

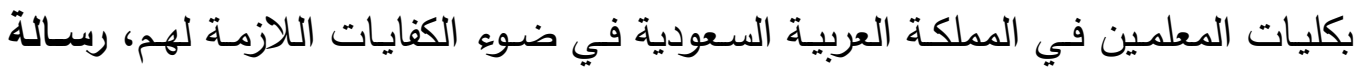
دكتوراه، كلية التربية، جامعة الأزهر.

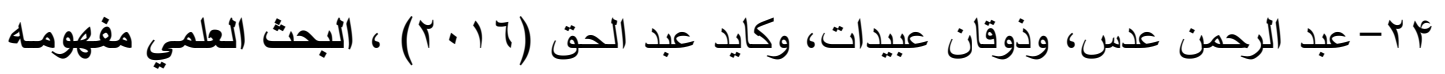

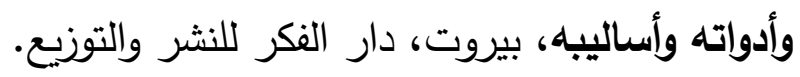

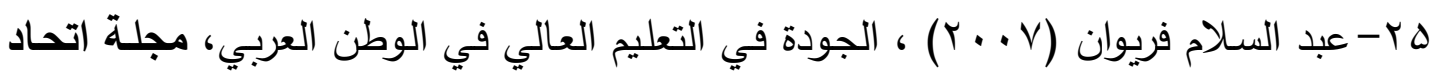

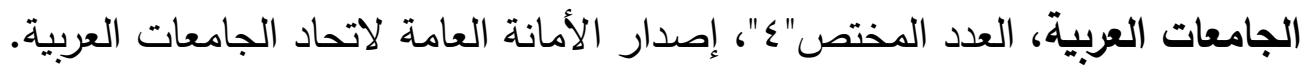

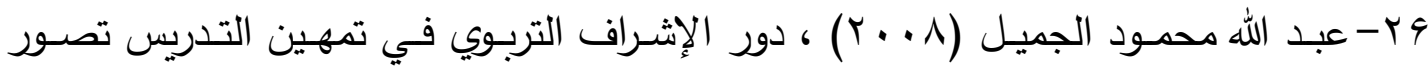

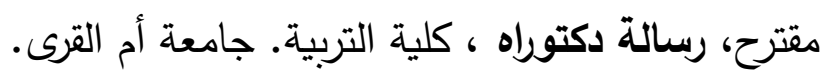

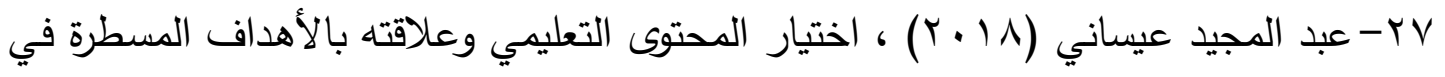

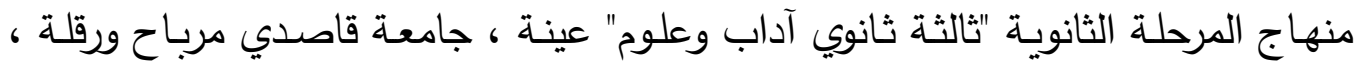

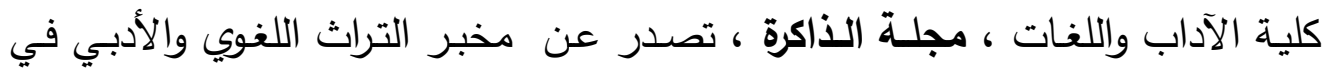

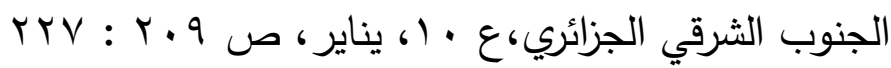

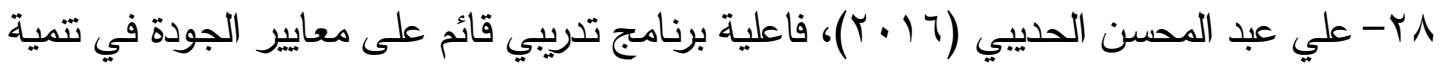

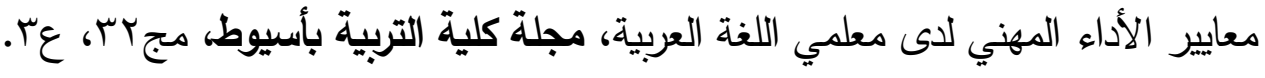

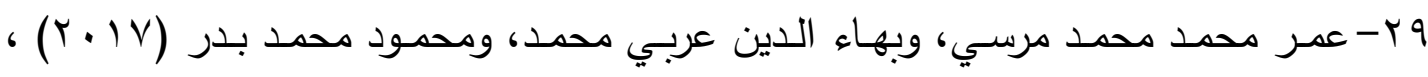
متطلبات إعداد الطالب المعلم بكليات التربية في جمهورية مصر العربة العربية لمواكبة سوق

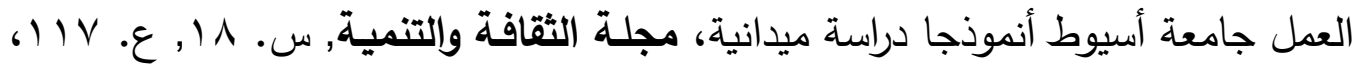

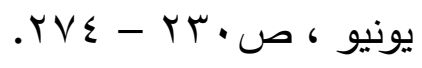




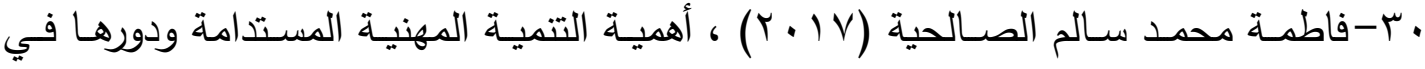

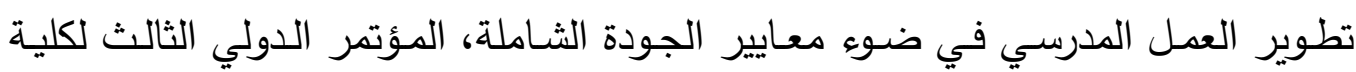
التربية جامعة 7 أكتوبر بالتعاون مع رابطة التربويين العرب بعنوان: مستقبل إعداد المعلم

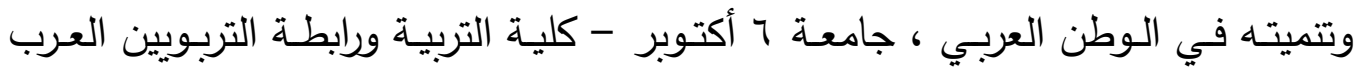

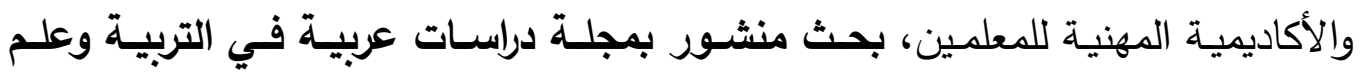

$$
\text { النفس،عدد خاص ، مج (7)، أبريل. }
$$

اب-فايزة عبد العاطي نور (10 ب ب) ، نموذج مقترح لبناء معايير التمية المهنية لدى معلم

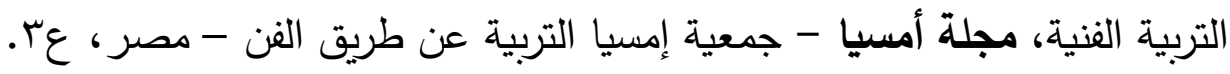

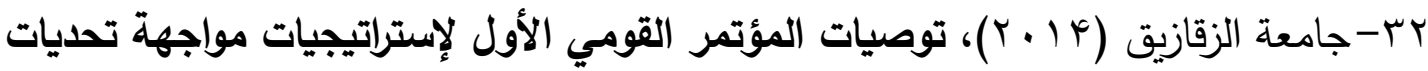

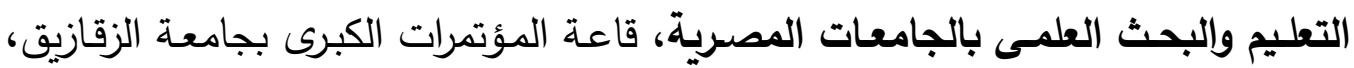

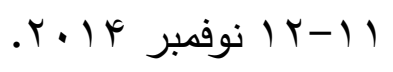

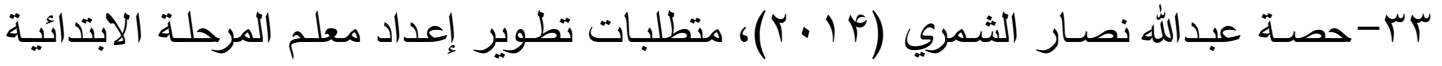

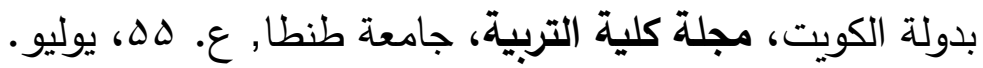

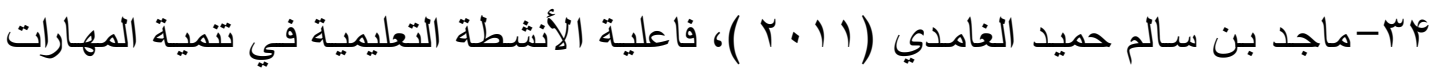
الحياتية في مقرر الحديث لطالب الصف الثالث المتوسط، رسالة ماجستير، كلية العلوم الاجتماعية ، جامعة الإمام محمد بن سعود الإسلامية.

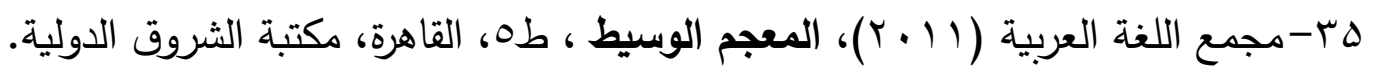

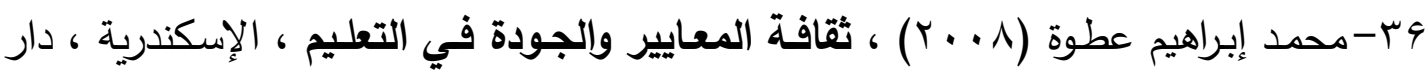

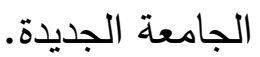

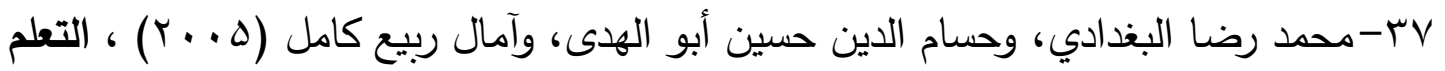
التعاوني ، القاهرة ، دار الفكر العربي.

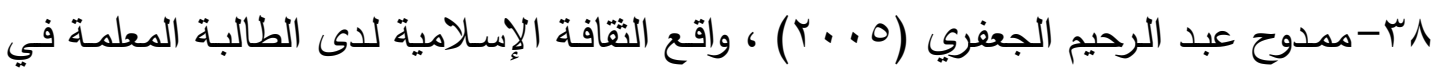

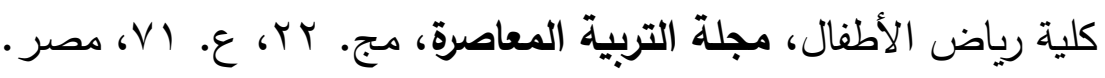

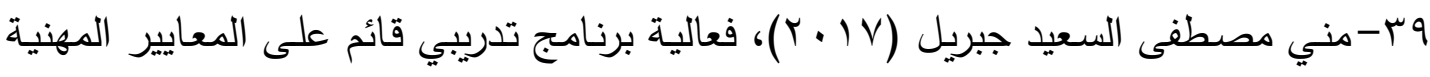

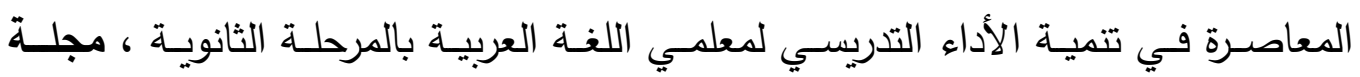

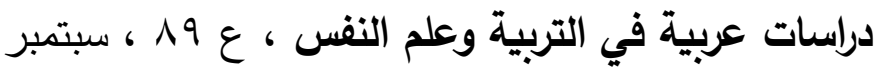




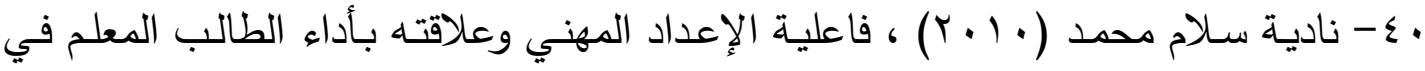

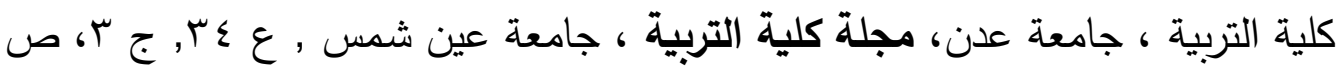

$$
. r \cdot 1-r+9
$$

اء- نضـال عبشي، تصور مقترح لتطوير برامج إعداد المعلم في كليات التربية على ضوء

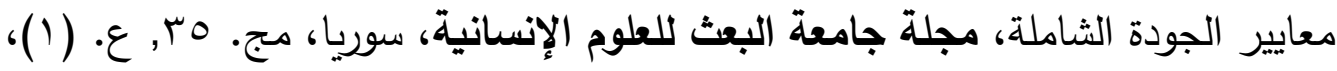

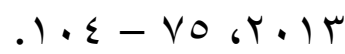

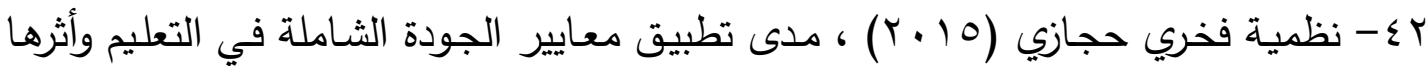

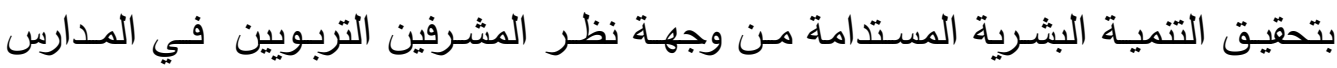

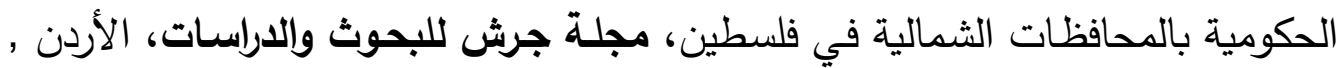

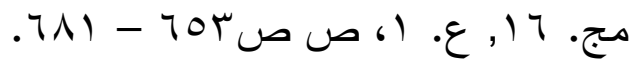

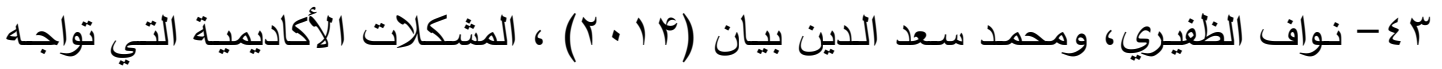
طلبة كليات التربية وعلاقتها ببعض المتغيرات من وجهة نظر الطلبة دراسة ميدانية على

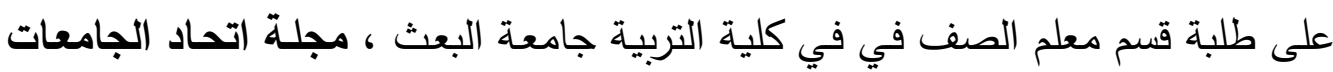

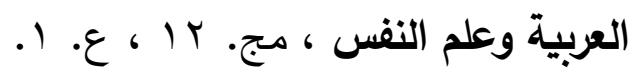

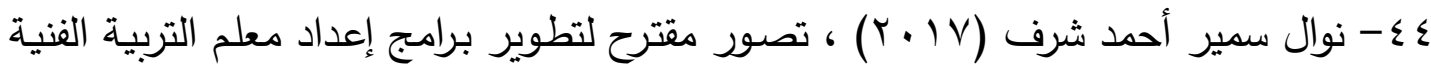

بكليات التربية النوعية في ضوء مهارات القرن الواحد والعشرين، المؤتمر الدولي الثالث لكلية التربية جامعة ج أكتوبر بالتعاون مع رابطة التربويين العرب بعنوان: مستقبل إعداد العبداد

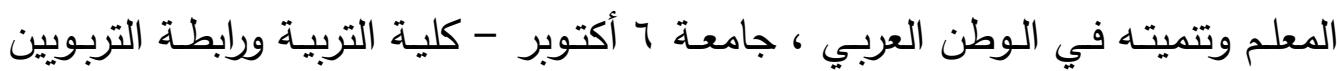

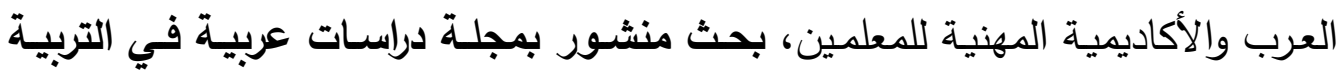

$$
\text { وعلم النفس،عدد خاص ، مج (1) (1)، أبريل. }
$$

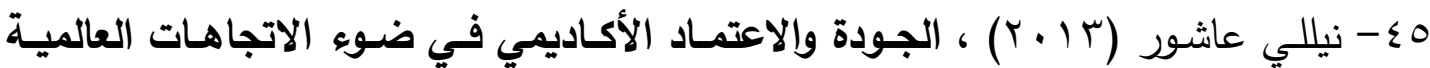

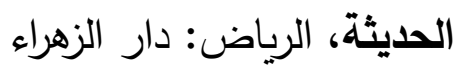

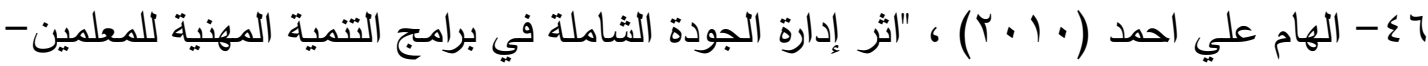

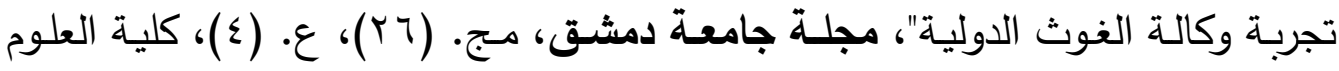
التربوية الجامعية، عمان - الأردن.

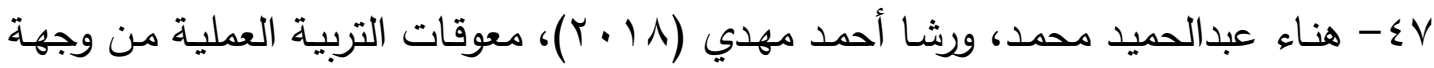

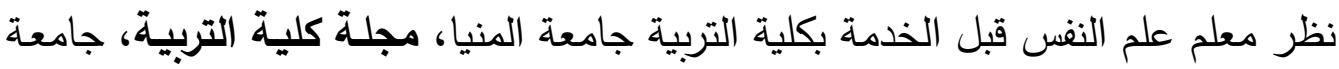

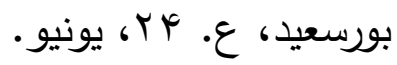




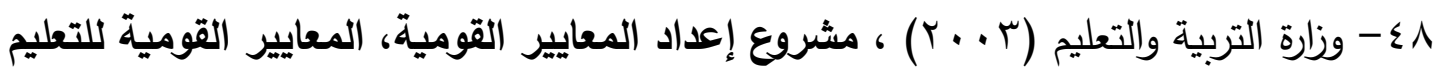
فى مصر ، الأمل للطباعة والنشر ، القاهرة.

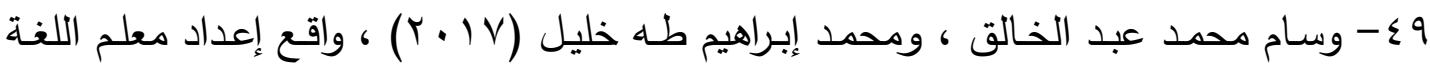

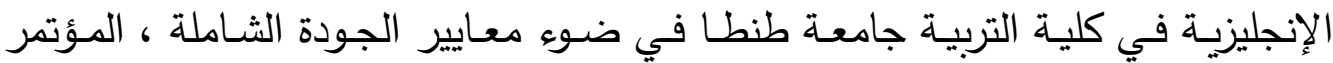

الدولي الثالث لكلية التربية جامعة 1 أكتوبر بالتعاون مع رابطة التربويين العرب بعنوان :

مستقبل إعداد المعلم وتتميته في الوطن العربي ، جامعة جأكتوبة أكتوبر - كلية التربية ورابطة

التربويين العرب والأكاديمية المهنية للمعلمين ، مجلة دراسـات عربية في في التربية التربية وعلم

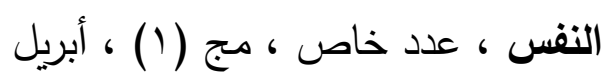

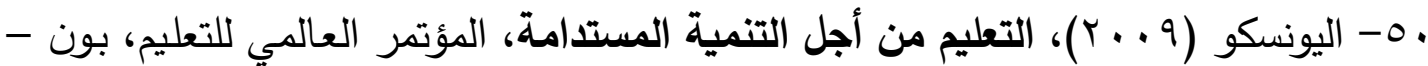
ألمانيا.

\section{ثانيا : المراجـــــ الأجنبيـــة:}

51- Adedoyin, O,. "(2010, jun.), Factor-Analytic study of Teacher's perceptions on self - Efficacy in Botswana Junior secondary schools: Implications for Educational : Quality, European Journal of Educational studies, 2 (2), PP. 139-155.

52- AITSL (2011) Australian National Professional Standards for Teaching. Available in www.aitsledu.au

53- Attino, A. R. (2012, April), Academic self-efficacy: from educational theory to instructional practice. Perspect Med Educ, 1(2), PP. 76-85.

54- City, E. A., \& Elmore, R. F. (2010), Instructional rounds in education: A network approach to improving teaching and learning. Cambridge, MA: Harvard Education Publishing Group.

55- Council of Chief State School Officers. (2013, April), Interstate Teacher Assessment and Support Consortium In TASC Model Core Teaching Standards and Learning Progressions for Teachers 1.0: A Resource for Ongping Teacher Development. Washington,. DC: Author.

56- Department of Education (2013), Teachers Standards. Available;at wwwrgov.uk Department of Education \& Early Development (2013) standards for Alaska Teachers.Website:http://education.alaska.gov/standards/pdf/teacher . pdf 15/11/2013. 
57- Friedman, A. (2012), Continuing professional development. New York, NY: Routledge.

58- Fullan, M. (2011), change leader: Learning to do what matters most. New York, NY: Wiley.

59- Grossman, G. M.; Onkol, P. E. \& Sands, M. (2007), Curriculum reform in Turkish teacher education: Attitudes of teacher educators towards change in an EU candidate nation. International Journal of Educational Development, 27 (2), pp 138-150.

60- Interstate New Teacher Assessment and Support Consortium Science Standards Drafting Committee (2005), Modal Standards in Science for Beginning Teacher Licensing and Development: A Resource for State Dialogue. Available on Web site: < http://www.ccsso.org projects Intestate_New_Teacher

61- Marrero,M.E., Woodruff,K.A., Schuster,G.S.,\& Riccio,J.F.( 2010),Live, Online Short. Courses : A Case Study Of Innovative Teacher Professional Development International Review Of Research In Open and Distance Learning, 11(1), 81-95.

62- Nadar, Fargany, Two Crucial Challenges to Human Development in the Arab Region: Governance Refarm and Knowledge Acquisition, Almishkat Centre for Research, Egypt, May, 2010.

63- NYSTS.(2011), The New York State Teaching Standards. Available in www.nvsed.gov

64- Opfer, V.\& Pedder, D. (2010) Benefits, Status and Effectiveness of Continuous Professional Development for Teachers in England. The Curriculum Journal, 21 (4), 413- 431.

65- Samuel E. O. Aduwa-Ogiegbaen , ( 2009 ), Nigerian InserviceTeachers' Self Assessment in Core Technology Competences and Their Professional Development Needs in ICT. Eric , EJ856113.

66- UNESCO (2005) , http://portal.unesco.org/education/ United Nations Decade of Education for Sustainable Visual and Performing Arts Framework Visual and Performing Arts Framework for Califomia Public School.

67- United Nations, (2017) Governance for Sustainable Human Development, January. 